\title{
POTENCIÁLIS FARMAKONOK ENANTIOSZELEKTÍV KROMATOGRÁFIÁS VIZSGÁLATA
}

\author{
Ph.D. Értekezés
}

Készítette:

Orosz Tímea

Témavezető:

Dr. Ilisz István

intézetvezető egyetemi docens

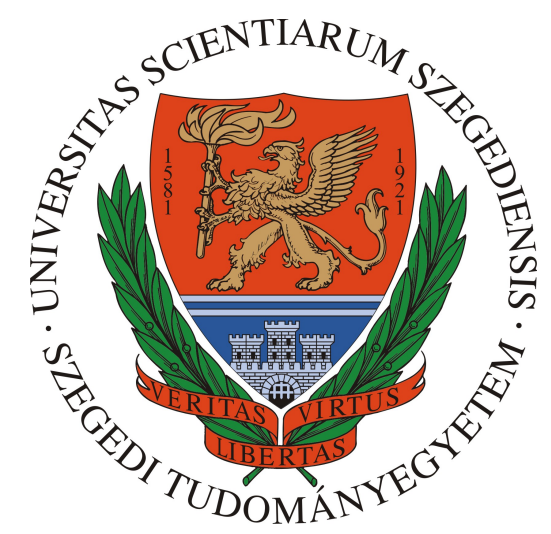

\section{SZEGEDI TUDOMÁNYEGYETEM}

Gyógyszerésztudományi Kar

Gyógyszeranalitikai Intézet

Kémia Doktori Iskola

SZEGED 


\section{Tartalomjegyzék}

Az értekezésben használt rövidítések jegyzéke.............................................................. 1

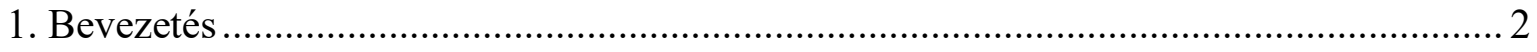

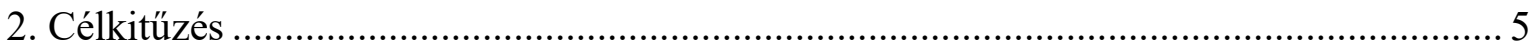

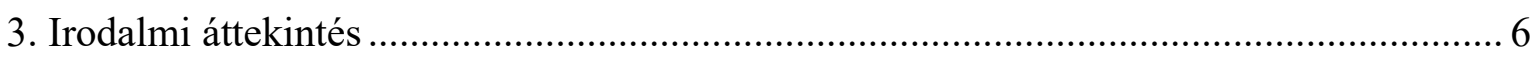

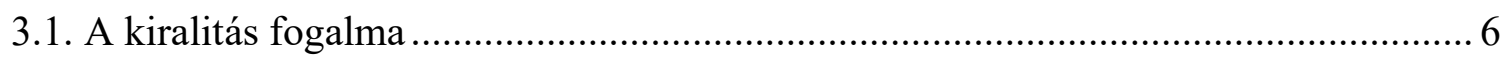

3.2. Enantiomerek folyadékkromatográfiás elválasztási lehetőségei .............................. 7

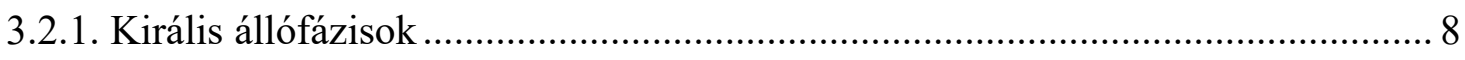

3.2.1.1. Makrociklusos antibiotikum (glikopeptid) alapú állófázisok ...................... 10

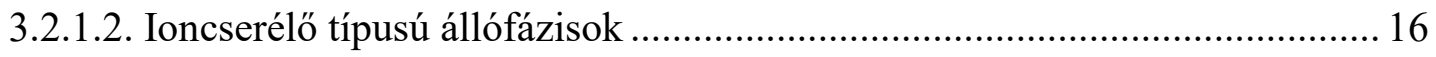

3.2.1.3. Módosított poliszacharid alapú állófázisok …............................................... 19

3.3. Szuperkritikus állapotban (vagy annak közelében) levő eluens alkalmazása

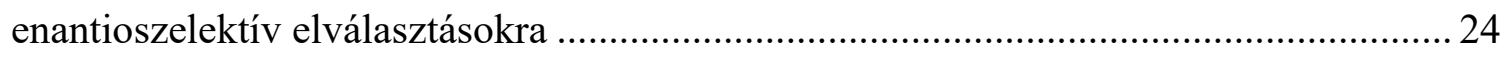

3.4. A kromatográfiás elválasztás hőmérsékletfüggése és termodinamikai háttere ......... 27

3.5. A vizsgált vegyületek kémiai, biológiai és farmakológiai jelentősége ..................... 30

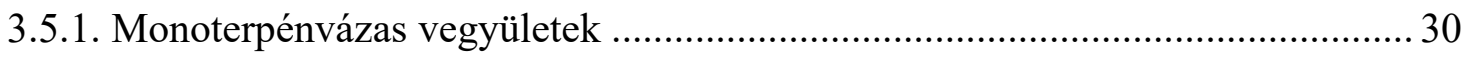

3.5.1.1. Limonén alapú karbociklusos $\beta$-aminosavak .............................................. 30

3.5.1.2. Biciklusos aminoalkoholok és aminodiolok ............................................. 30

3.5.2. $N$-metilszubsztituált és amidált ciklusos $\beta$-aminosavak .................................. 31

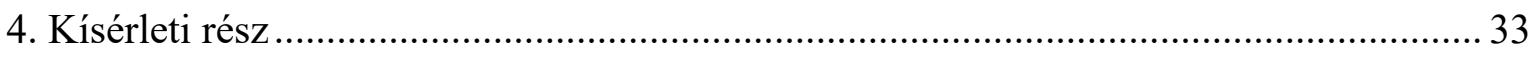

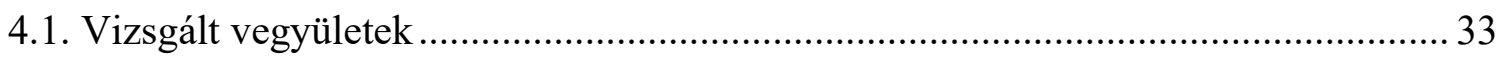

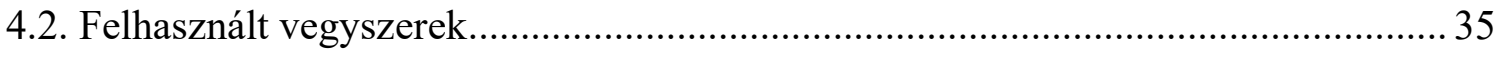

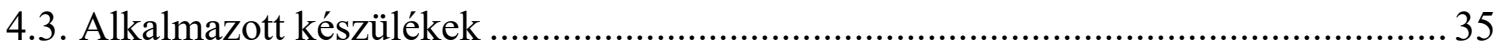

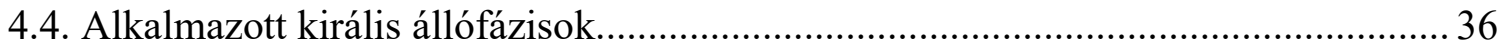

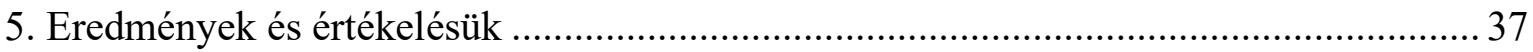

5.1. Limonén alapú karbociklusos $\beta$-aminosavak elválasztása makrociklusos glikopeptid

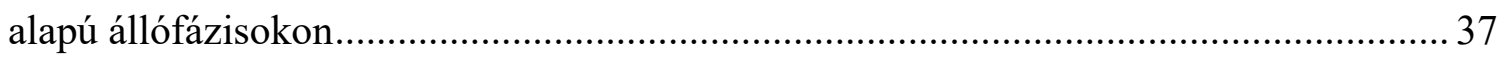

5.1.1. A mozgófázis összetevőinek hatása az elválasztásra..................................... 37

5.1.1.1. A mozgófázis pH-jának hatása a kromatográfiás viselkedésre .................... 37

5.1.1.2. Eluensösszetétel-változás hatása az elválasztásra ..................................... 38

5.1.1.3. A mozgófázist alkotó alkohol anyagi minőségének hatása .......................... 41 
5.1.1.4. Ellen- és kísérő ionok koncentrációjának hatása 42

5.1.2. A szénhidrátegységek hatása a királis felismerésre. 44

5.1.3. A hőmérséklet hatása és termodinamikai paraméterek 46

5.2. $N$-metilszubsztituált és amidált ciklusos $\beta$-aminosavak elválasztása ikerionos állófázisokon 50

5.2.1. A mozgófázis összetételének hatása az elválasztásra 50

5.2.1.1. Eluensösszetétel-változás hatása a kromatográfiás paraméterekre 50

5.2.1.2. Ellen- és kísérőionok koncentrációjának hatása az elválasztásra .53

5.2.2. Az aminocsoport szubsztituáltságának hatása a kromatográfiás viselkedésre ... 54

5.2.3. A hőmérséklet hatása és termodinamikai paraméterek .58

5.3. Limonén alapú biciklusos aminoalkoholok és aminodiolok elválasztása poliszacharid alapú állófázisokon NP-LC és SFC technikák alkalmazásával 61

5.3.1. A mozgófázis összetevőinek hatása az elválasztásra...................................... 61

5.3.1.1. A mozgófázist alkotó alkohol anyagi minőségének hatása ......................... 61

5.3.1.2. Az eluensösszetétel-változás hatása a kromatográfiás paraméterekre ......... 63

5.3.2. A szerkezet és a retenció közötti összefüggések tanulmányozása...................... 65

5.3.3. A hőmérséklet hatása és termodinamikai paraméterek..................................... 71

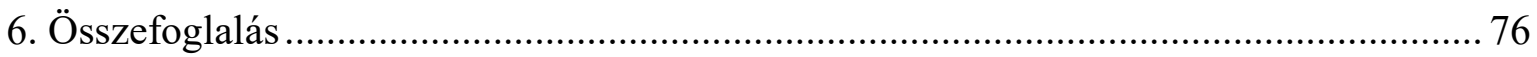

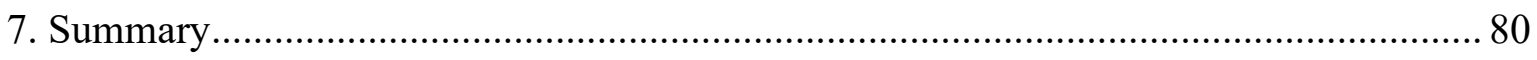

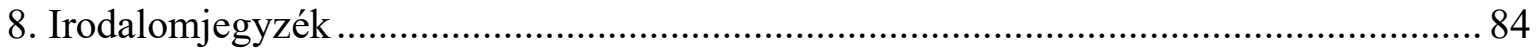

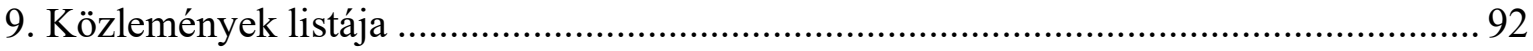

9.1. Az értekezés alapjául szolgáló közlemények ……………....................................... 92

9.2. Az értekezés témájához kapcsolódó, de fel nem használt közlemények .................. 93

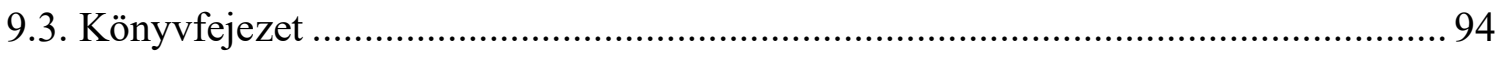

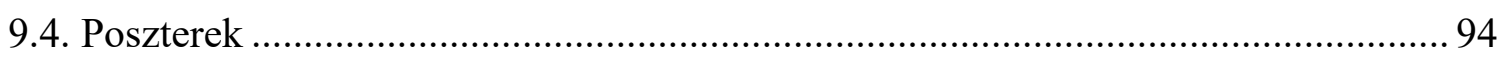

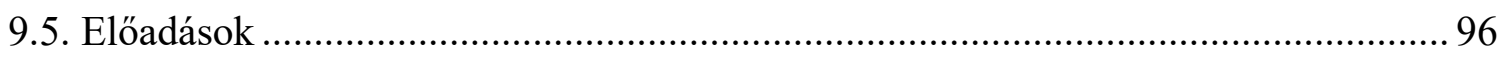

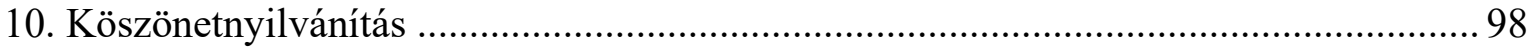

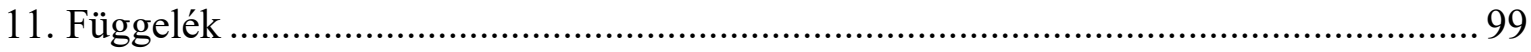




\section{Az értekezésben használt rövidítések jegyzéke}

AcOH: ecetsav

BuOH: butanol

t-BuOH: 2-metil-2-propán-ol

CE: kapilláris elektroforézis (capillary electrophoresis)

DEA: dietil-amin

EtOH: etanol

FA: hangyasav

FDA: amerikai kormányhivatal (Food and Drug Administration)

Fmoc: 9-fluorenil-metiloxi-karbonil

GC: gázkromatográfia (gas chromatography)

HPLC: nagyhatékonyságú folyadékkromatográfia (high-performance liquid chromatography)

MeCN: acetonitril

MeOH: metanol

NP: normál fázisú mód (normal phase)

NP-LC: normál fázisú folyadékkromatográfia

PI: poláris-ionos mód (polar-ionic)

PO: poláris-szerves mód (polar-organic)

PrOH: $n$-propanol

2-PrOH: propán-2-ol

QD: kinidin (quinidine)

QN: kinin (quinine)

RP: fordított fázisú mód (reversed phase)

SCX: erős kationcserélő (strong cation exchanger)

SFC: szuperkritikus folyadékkromatográfia (supercritical fluid chromatography)

TEA: trietil-amin

TEAA: trietilammónium-acetát

UV: ultraibolya spektrum (ultraviolet)

WAX: gyenge anioncserélő (weak anion exchanger) 


\section{Bevezetés}

Napjainkban a természettudományok, valamint a szerves kémiai- és gyógyszeripar rohamosan fejlődő virágkorát éljük. Az analitikai kémia számos tudományterületen jutott döntő szerephez, melyek előrehaladása elképzelhetetlen a nagyszámú pontos és precíz analitikai mérési eredmények nélkül. Ilyen igényeknek gyors és hatékony analitikai módszerek, valamint egyre nagyobb teljesítőképességü és robusztusabb mérőmüszerek tudnak eleget tenni. A müszeres analitikai technikák rendkívül gyors fejlődése segíti az előrehaladást, melynek egyik legnagyobb húzóágazata a gyógyszeripar. Mire egy potenciális gyógyszerhatóanyag kezdeti szintézisétől a végtermék kereskedelmi forgalomba hozataláig eljutunk, a gyógyszerfejlesztés folyamata egy, vagy akár két évtizedig is eltarthat. A ma hatályos gyógyszerkönyvek irányelvei egyre szigorúbb mértékben szabályozzák a gyógyszerhatóanyagok tisztaságára vonatkozó követelményeket, amely szükségessé teszi az újabb, kisebb kimutatási határokat biztosító, s egyben költséghatékonyabb módszerek bevezetését.

Az élő szervezetek felépítésében részt vevő biomolekulák, úgy mint a fehérjék, a fehérjéket alkotó aminosavak a glicin kivételével, a cukrok és az enzimek nagy része királis vegyület. A királis vegyületek enantiomerei ellentétes optikai aktivitással, míg megegyező fizikai-kémiai sajátossággal bírnak. Amennyiben egy racém, azaz enantiomereket azonos arányban tartalmazó vegyület királisan szelektív élő szervezetbe kerül, az enantiomerek jelentősen eltérő biológiai és farmakológiai viselkedést mutathatnak. Ennek értelmében az enantiomer molekulapárok közül míg az eutomer az alkalmazni kívánt pozitív terápiás hatásért felelős, addig a másik izomer, az úgynevezett disztomer inaktív vagy kedvezőtlen, olykor akár toxikus hatást fejthet ki az emberi szervezetbe kerülve [1]. Érthető tehát, hogy a biológia, de legfőképp a gyógyszerkutatás területén rendkívüli igény lépett fel a királis elválasztási módszerek fejlesztése iránt annak érdekében, hogy ezek a vegyületek királisan tiszta formában álljanak rendelkezésre. Ennek szükségességét nem lehet elégszer hangsúlyozni, hiszen mára a szigorodott szabályozásoknak köszönhetően racém hatóanyag csak rendkívül indokolt esetben kerülhet forgalomba, miután mind a két enantiomerre és magára a racém vegyületre is elvégezték az összes szükséges klinikai és toxikológiai vizsgálatot [2]. Természetesen ez hatványozottan megdrágítja a királis gyógyszerhatóanyagok kereskedelmi forgalomba hozatala elötti fejlesztések folyamatát, ennélfogva napjainkban a kutatások és fejlesztések egy gazdaságosabb irányvonalat követnek, amely nem más, mint a tiszta enantiomerek előállítása. 
A jelenleg használt gyógyszerek több, mint 50\%-a királis hatóanyagot tartalmaz. Egy 2017-ben megjelent közlemény az amerikai élelmiszereket és gyógyszereket felügyelő hatóság (FDA) által engedélyezett új, királis hatóanyagot tartalmazó gyógyszerek számát vizsgálta 2002 és 2015 között (1. ábra). Ezen időszak alatt az újonnan engedélyezett, racém hatóanyaggal bíró gyógyszerek számának jelentős csökkenése volt megfigyelhető, mellyel párhuzamosan került egyre inkább előtérbe az enantiomertiszta formában való forgalmazás [3].

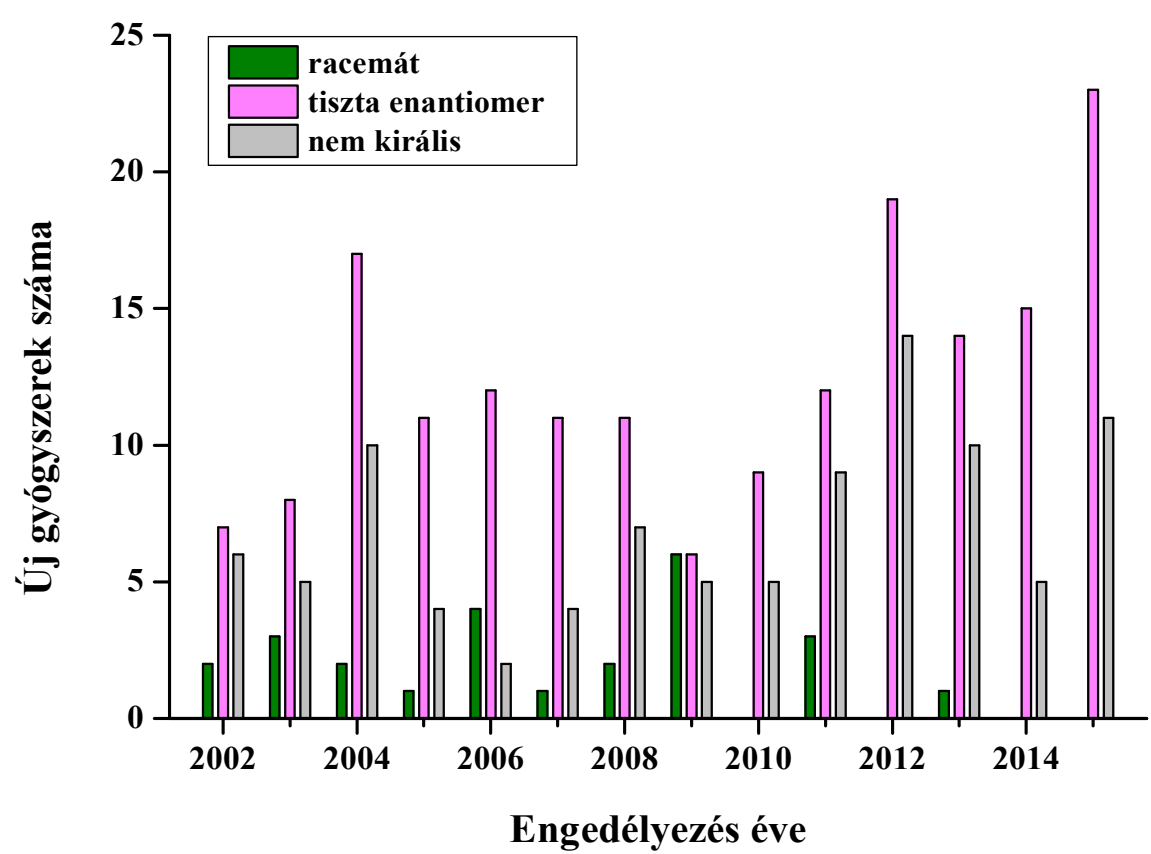

1. ábra Az FDA által engedélyezett racém, enantiomertiszta, illetve nem királis hatóanyagok számának alakulása 2002 és 2015 közötti időszakban [3].

Az elmúlt húsz évben a királis technológia területe ugrásszerü fejlődésen ment keresztül, melynek fejlesztésére ma is tekintélyes figyelem irányul. A különféle élelmiszeradalékanyagok, agrokemikáliák, valamint a petrolkémia- és a kozmetikai ipar legkülönbözőbb termékei arra engednek következtetni, hogy számos ipari területen egyre inkább fokozódik az igény a királisan tiszta vegyületek előállítása iránt. Enantiomertiszta vegyületek előállítására több lehetőség is kínálkozik. Ezek közé tartozik a racém elegyek elválasztása, az enantioszelektív szintézisek végrehajtása, valamint a királisan tiszta forrás használatán alapuló módszerek alkalmazása. Sok esetben hatékony és kevésbé költséges megoldást jelent a racém elegyek elóállítása, majd ezt követően egy alkalmas elválasztástechnikai módszer segítségével az enantiomerek elválasztása. 
A jelenkori gyógyszeranalitika egyik legnagyobb kihívása a biológiai és farmakológiai jelentőséggel bíró királis vegyületek enantiomereinek elválasztása, mely kulcsfontosságú az enantiomer tisztaság ellenőrzése szempontjából. Erre a célra a leggyakrabban alkalmazott módszerek a kromatográfia családjából kerülnek ki, melyek közül a legelterjedtebben használt és napjainkban is dinamikusan fejlödő technika a nagyhatékonyságú folyadékkromatográfia (HPLC), a módszer kínálta számos előnyös lehetőségnek köszönhetően. Természetesen ezen analitikai feladat megoldására sok esetben megfelelö választás a gázkromatográfia $(\mathrm{GC})$ is. Fontosnak tartom kiemelni, hogy a szuperkritikus folyadékkromatográfia (SFC) egyre inkább kezd előtérbe kerülni a technikai fejlesztéseknek köszönhetően. Továbbá az elválasztástechnikai módszerek közé tartozó kapilláris elektroforézis (CE) is sok esetben alkalmas stratégiának bizonyul az enantiomerek megkülönböztetésére [4]. Amennyiben nagyobb mennyiségü, enantiomertiszta vegyületek előállítása a cél, a leghatékonyabb és leggazdaságosabb megoldást a HPLC és az SFC technikák kínálják. 


\section{Célkitüzés}

Munkám során célul tüztem ki biológiai és gyógyszerkémiai jelentőséggel rendelkező potenciális farmakonok enantioszelektív folyadékkromatográfiás vizsgálatát, a sztereoizomerek elválasztásának optimalizálását, valamint újabb fejlesztésủ királis állófázisok elválasztóképességének kromatográfiás jellemzését.

A királis felismerési folyamatok szerkezetfüggésére fókuszálva tanulmányozni kívántam:

$\star$ limonénvázas karbociklusos $\beta$-aminosavak enantiomerjeinek elválasztását makrociklusos (glikopeptid) alapú (Chirobiotic ${ }^{T M} R, T$ és $T A G$ ) királis állófázisokon,

$\star N$-metilszubsztituált és amidált ciklusos $\beta$-aminosav enantiomerek retenciójának mechanizmusát ikerionos ioncserélő típusú (Chiralpak ${ }^{\circledR} Z W I X(+)$ és $\left.Z W I X(-)\right)$ oszlopokon,

^ limonén alapú biciklusos aminoalkoholok és aminodiolok enantiomerjeinek folyadékkromatográfiás elválasztását módosított poliszacharid királis szelektort tartalmazó (Lux Cellulose-1, Lux Cellulose-2, Lux Cellulose-3, Lux Cellulose4, Lux i-Cellulose-5, Lux Amylose-1 és Lux Amylose-2) állófázisokon.

A modellvegyületek közvetlen királis folyadékkromatográfiás vizsgálatán keresztül tanulmányozni kívántam a mozgófázis összetételének és a poláris módosító (alkohol) anyagi minőségének az elválasztásra gyakorolt hatását.

További célom volt a kromatográfiás paraméterek változásának nyomonkövetésével az elválasztani kívánt vegyületek, valamint az alkalmazott királis szelektorok szerkezete és a királis megkülönböztetési folyamatok közötti összefüggések felderítése.

Ezen felül a hőmérséklet kromatográfiás paraméterekre gyakorolt hatásának vizsgálatával, illetve termodinamikai paraméterek meghatározásával lehetőség nyílt az elválasztás lehetséges mechanizmusának feltérképezésére. 


\section{Irodalmi áttekintés}

\subsection{A kiralitás fogalma}

Több, mint másfél évszázada ismeretes, hogy a szervetlen és szerves vegyületek között nagy számmal fellelhetők olyan molekulák, amelyek képesek a lineárisan polarizált fény polarizációs síkjának elforgatására. Ezek az optikailag aktív, illetve napjainkban leginkább királisnak nevezett vegyületek, melyek molekulái egymással fedésbe nem hozható, aszimmetrikus molekula alkattal rendelkeznek. A szerves molekulák szerkezete és optikai aktivitása közti összefüggés kutatása a XIX. század elejére vezethető vissza, amely főként Berzelius, Biot és Mitscherlich kutatásain alapszik. 1848-ban Pasteur értelmezte az optikai izoméria jelenségét az optikailag inaktív szőlősav (racém borkősav) nátriumammónium só kristályainak tanulmányozásán keresztül. Mérföldkőnek számító felfedezése után 1874-ben van't Hoff-nak és Le Bel-nek sikerült egymástól függetlenül az optikai izoméria szabatos értelmezése [5]. Innentől vette kezdetét a modern sztereokémia tudománya, amely az atomok, illetve az atomcsoportok molekulán belüli viszonyait kutatja.

Louis Pasteur következtetéseit figyelembe véve máig is helytálló módon megfogalmazható, hogy optikailag aktívak azok a vegyületek, amelyek a lineárisan polarizált fény síkját elforgatni képesek. Ezen vegyületek balra forgató (-) és jobbra forgató (+) módosulatait különböztethetjük meg. Az első esetről akkor beszélünk, ha a polarizációs sík elfordulása - a fény terjedési irányába tekintve - az óramutató járásával ellentétes iránynak felel meg, jobbra forgató módosulat pedig akkor áll fenn, ha az óramutató járásával egybeesik. A két optikailag aktív módosulat mind fizikai, mind kémiai tulajdonságaikban megegyezik egymással. Az optikai forgatóképesség tekintetében abban is megegyeznek, hogy azonos körülmények között mért forgatásuk abszolút értéke megegyező. Azon vegyületeket, melyek ilyen tulajdonságú módosulattal rendelkeznek, egymás enantiomereinek tekinthetők. A két enantiomer viszonyban lévő módosulat bruttó képlete és kémiai szerkezete megegyező, a közöttük levő különbség csupán az atomok térbeli elrendeződésében mutatkozik meg, tehát sztereoizomerek. Az enantiomerek 1:1 arányú keveréke optikailag inaktív, melyet racém vegyületpárnak nevezünk.

A molekula kiralitását létrehozó szerkezet elemeinek elrendeződése történhet egy központra, egy tengelyre, egy síkra vonatkoztatva, ugyanakkor egy csavarvonal szerint is definiálható. Ez alapján a kiralitás különböző típusait, úgy mint a centrális, axiális vagy planáris kiralitást, illetve hélixszerkezetủ rendszereket különböztethetünk meg. A kiralitás 
legegyszerübb esete akkor áll fenn, amikor egy szénatomhoz (aszimmetriacentrumhoz) négy különböző atom vagy atomcsoport (szubsztituens) kapcsolódik. Azt nem szabad elfelejteni, hogy a kiralitáscentrum megléte nem szükséges feltétele a kiralitásnak. Erre alkalmas példa az axiális- és a planáris kiralitás esete. Olyan molekulákkal is találkozhatunk, amelyekben két szénatom helyezkedik el oly módon, hogy kötési irányuk két különböző síkban foglal helyet. Az említett szénatomokhoz kapcsolódó négy különbözö szubsztituens által a vegyület királissá válik. Ebben az esetben négy helyett elegendő két különböző szubsztituens megléte az optikai izoméria kialakulásához. Léteznek olyan aszimmetrikus centrummal rendelkező párosítások is, amelyek nem rendelkeznek tükörkép jelleggel. Ezeket a vegyületeket diasztereomereknek nevezzük, amelyek kémiai és/vagy fizikai jellemzőit tekintve (pl. reakciókészség, olvadás- és forráspont, optikai forgatóképesség, stb.) már különböznek egymástól [6]. Az enantioméria és diasztereoméria viszonyt a 2. ábrán szemléltetem.

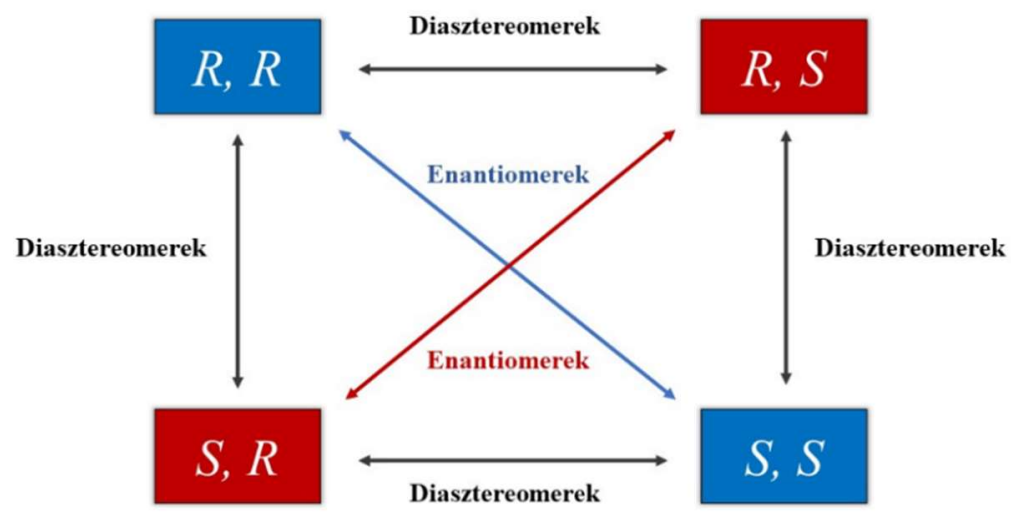

2. ábra Sztereoizomerek csoportosítása

\subsection{Enantiomerek folyadékkromatográfiás elválasztási lehetőségei}

Az élő szervezetekben előforduló királis vegyületek tudományos érdekességükön túlmenően óriási gyakorlati jelentőséggel rendelkeznek. Nem véletlen tehát, hogy nem csak kutatási szinten, de az ipar is a királis molekulák enantiomertiszta formában történő előállítására törekszik. Kezdetben a királis analízis nehéz analitikai feladatnak bizonyult, s a legtöbb elválasztást analízis előtti származékképzéssel végezték el. Ma már számos elválasztástechnikai módszer nyújt megoldást az enantiomerek megkülönböztetésére, melyek közül analitikai célokra a kapilláris elektroforézis és a kromatográfiás technikák a leggyakrabban alkalmazottak. 
A HPLC a gyors analízis, a reprodukálhatóság, az érzékenység és a mozgó-, valamint az állófázisok széleskörü változtatása révén napjaink legígéretesebb módszere a királis elválasztás területén. A legtöbb kromatográfiás módszernél (a királis ligandumcserekromatográfia kivételével) az elválasztás alapjául az elválasztani kívánt vegyület és az állóvagy a mozgófázis királis komponense között létrejövő időleges diasztereomerpár-képzés szolgál.

Az optikai izomerek folyadékkromatográfiás elválasztására alkalmazható stratégiákat két fő csoportba sorolhatjuk:

1. közvetett meghatározás - királis reagens segítségével oszlop előtti származékképzés,

2. közvetlen meghatározás - királis adalék alkalmazása a mozgófázisban, illetve királis állófázis használata.

$\mathrm{Az}$ értekezésemben bemutatott kísérleti munka a közvetlen kromatográfiás módszereken belül királis állófázisok (oszlopok) alkalmazásán alapul, ezért a továbbiakban a királis oszlopok alkalmazhatóságának lehetőségeit, valamint a vizsgálataink során használt különféle királis állófázis típusok jellegzetességeit tárgyalom részletesebben.

\subsubsection{Királis állófázisok}

A HPLC technika kulcsfontosságú szerepet tölt be az enantiomerek széles körü hatékony királis felismerésében, valamint a különböző királis állófázisok kialakításában és fejlesztésében. Számos királis állófázist készítettek HPLC analízisekhez, amelyek királis molekulákból vagy királis polimerekből állnak. Királis oszlop segítségével megvalósított kutatásról legelőször Henderson és Rule számoltak be [7]. Az analitikai kémia területén jelentkező állandó kihívások, valamint a kromatográfiás müszerezettség intenzív fejlődésének következtében az újabb, minél több kölcsönhatás kialakítására képes szelektorok elöállítása még ma is fontos téma kutatási szinten. Az elmúlt évtizedben számos állófázis típust fejlesztettek ki [8-11], közülük több, mint kétszáz már kereskedelmi forgalomban is elérhető [12].

A királis oszlopok napjainkra is jellemző térhódítása jelentős mértékben visszaszorította a közvetett meghatározások számát. A módszer igen nagy előnye, hogy nem jár hosszadalmas és körülményes mintaelőkészítéssel, valamint az analízist követően a vizsgált vegyületek kinyerhetők, ennélfogva a királis állófázisok az analitikai (mennyiségi 
és minőségi) meghatározások mellett preparatív (enantiomerek tisztítása) célra is tökéletesen használhatók. A királis elválasztás során számos, különböző típusú kölcsönhatás alakulhat ki a vizsgált vegyület enantiomerei és az alkalmazott állófázis szelektora között. Természetesen ezek a kölcsönhatások függenek a mozgófázis összetételétől, így annak megválasztásával hangolható a jellemzö kölcsönhatások kialakulása. Az elúció sorrendje a legtöbb esetben előre nem megjósolható és a hatékony elválasztást lehetővé tevő kromatográfiás körülmények felderítése gyakran csak előzetes tapasztalatok figyelembevételével történik. A közvetlen módszer alkalmazásának hátránya, hogy a királis oszlopok beszerzése viszonylag költséges.

Amint azt a korábbiakban említettem, királis állófázis alkalmazása esetén a királis elválasztás hatékonyságát az enantiomerek szelektorral létesített eltérő kölcsönhatása határozza meg. A királis felismerés folyamatát leíró úgynevezett hárompontos illeszkedési modell (3. ábra) máig a legszélesebb körben elfogadott elmélet, melynek alapjait 1933-ban Easson és Stedman fektették le [13]. Azt feltételezték, hogy az általuk vizsgált enzimek aktív centrumához kapcsolódva legalább három ponton történő sztereoszelektív kölcsönhatás kialakítása szükséges a királis felismeréshez. Dalgliesh aminosavak papírkromatográfiás elválasztását tanulmányozta ezen szemléltetési mód segítségével [14]. Később Pirkle és Pochapsky [15], majd Davankov [16] kiegészítéseikkel finomították a modellt. Ök már a lehetséges vonzó kölcsönhatások mellett a taszító (sztérikus) hatások szerepeit is kihangsúlyozták, valamint felismerték, hogy a három szükséges kölcsönhatás közül legalább egynek sztereoszelektívnek kell lennie.
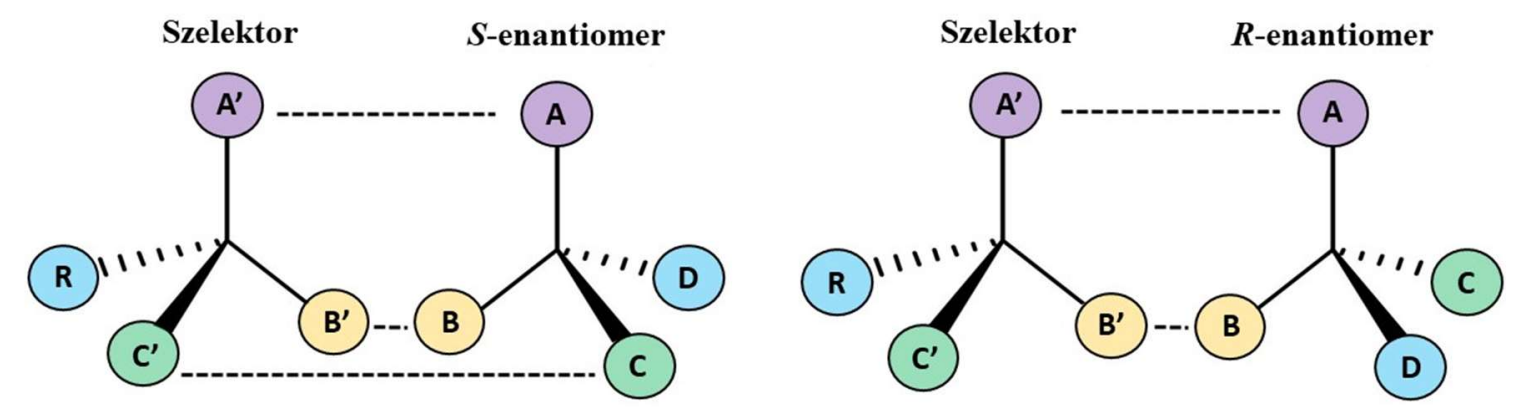

3. ábra A hárompontos illeszkedési modell

A közvetlen elválasztások során alkalmazott állófázisokat eredetük szerint három kategóriába sorolhatjuk, melyek a következők: természetes-, félszintetikus- és szintetikus alapúak. A királis állófázisok különböző fajtáit rendszerint az elválasztás mechanizmusa 
alapján szokás elkülöníteni. Ezen típusú besorolás alapján napjaink legnagyobb gyakorlati jelentőséggel bíró királis szelektorai a következők:

$\star$ poliszacharidok (módosított cellulóz és amilóz),

^ oligoszacharidok (ciklofruktánok, ciklodextrinek),

* fehérjék,

$\star$ aminosavak,

$\star$ ioncserélők,

^ makrociklusos vegyületek (koronaéterek, antibiotikumok),

$\star$ egyéb (molekulalenyomat- és szintetikus polimer alapú, donor-akceptor típusú) szelektorok.

Munkám során három állófázis típussal foglalkoztam, a következőkben ezek fontosabb sajátságainak és alkalmazásainak ismertetésére helyezem a hangsúlyt.

\subsubsection{Makrociklusos antibiotikum (glikopeptid) alapú állófázisok}

A makrociklusos glikopeptidek királis szelektorként történő folyadékkromatográfiás alkalmazását legelőször Armstrong és munkatársai mutatták be az 1994-ben megtartott Pittsburgh Konferencián [17]. Munkájuk során különböző kromatográfiás rendszerekben ugyanazon állófázist alkalmazva eltérő szelektivitás értékeket kaptak. Eredményeik alapján különböző királis felismerési folyamatokat sikerült felfedezniük [18, 19]. A poliszacharid típusú állófázisok mellett ma már az egyik legkeresettebb oszlopok a királis kromatográfia területén. Több száz rendkívül változatos szerkezettel és sokféle funkciós csoporttal rendelkező vegyület sorolható a makrociklusos antibiotikumok családjába, melyek között savas, bázikus és semleges karakterü molekulák egyaránt találhatók. Molekulatömegük jellemzően 600 és $2200 \mathrm{~g} / \mathrm{mol}$ közé esik [20].

A makrociklusos antibiotikumokon belül királis szelektorként alkalmazható molekulák az ansamicinek, a polipeptidek, a glikopeptidek, valamint az aminoglikozidok [20]. Közülük a glikopeptidek (teikoplanin, teikoplanin aglikon, risztocetin A, vankomicin és vankomicin aglikon) bizonyultak a legeredményesebbnek sztereoszelektivitás szempontjából, de értek el hatékony elválasztásokat avoparcin, fradiomicin, kanamicin, sztreptomicin, tiosztrepton és rifampicin alkalmazásával egyaránt [21]. Ezek az állófázisok az elmúlt két évtizedben intenzív fejlődésen mentek keresztül. 


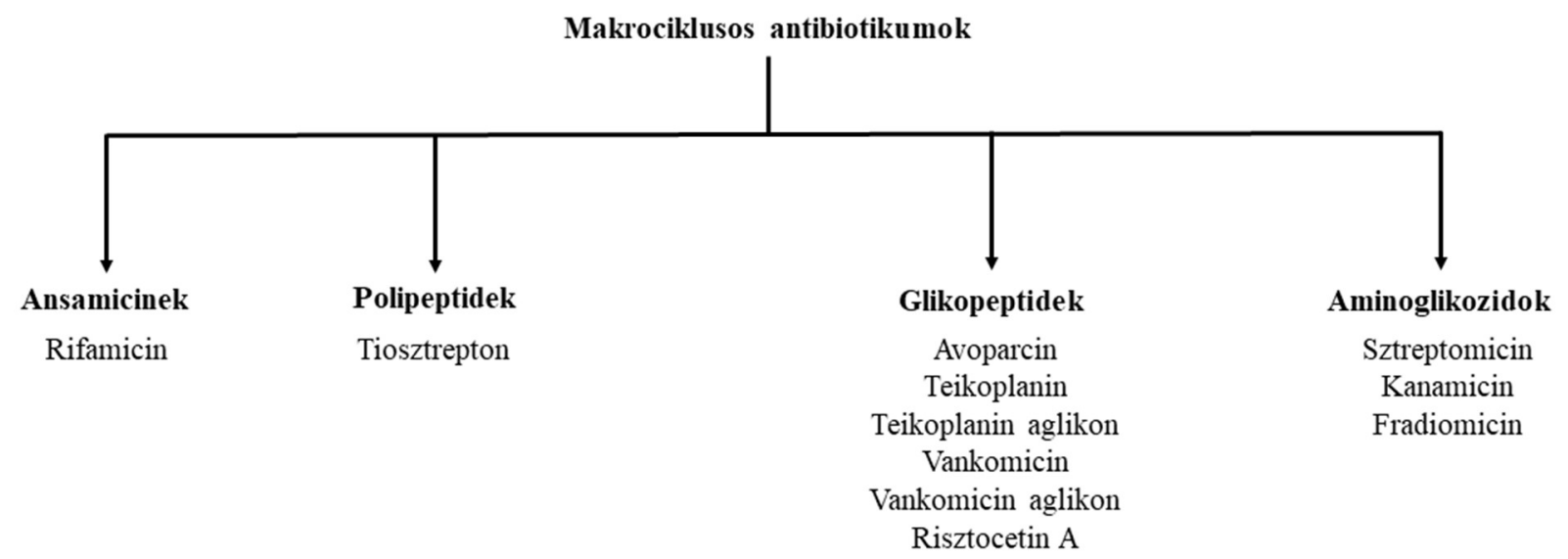

4. ábra A makrociklusos antibiotikumok csoportosítása [22]

Nagyfokú szerkezeti változatosságuknak köszönhetően a makromolekulák többféle minőségü és erösségü kölcsönhatás (elektrosztatikus, H-híd, hidrofób-hidrofób, $\pi-\pi$, sztérikus gátlás, stb.) kialakítására képesek, ebböl adódóan alkalmazhatóságuk a vizsgálandó vegyületek roppant széles körére terjed ki [23]. A kölcsönhatások változatosságából adódóan további elönyük, hogy multimodális oszlopok, azaz többféle kromatográfiás rendszerben is hatékonyan alkalmazhatók, úgy mint normál- (NP), fordított fázisú (RP), poláris-ionos (PI), valamint poláris-szerves (PO) módban [18, 24], de értek el sikeres elválasztásokat SFC-vel is [25]. A kromatográfiás módok változtatása eltérő enantioszelektivitás kialakulásához vezethet, hiszen a korábban említett szerkezeti sokféleség lehetövé teszi, hogy különbözö összetételü mozgófázisok alkalmazása révén egyazon királis szelektor esetén többféle mechanizmus kerüljön elötérbe az enantiomerek felismerése során. PO mód alkalmazása alatt nemvizes poláris szerves oldószer használatát értjük, míg PI módozat esetén a nemvizes poláris szerves oldószerelegyhez savas, illetve bázikus karakterü módosítót adagolunk, amely az ionos, vagy ionizálható vegyületek királis elválasztásánál játszik meghatározó szerepet.

A makrociklusos glikopeptid alapú királis állófázisokat Chirobiotic $^{T M}$ márkanév alatt forgalmazzák. Valamennyi Chirobiotic $^{T M}$ oszlop szerkezetéröl elmondható, hogy egy peptidváz kínál lehetőséget H-híd és dipólus-dipólus kölcsönhatások kialakulására, valamint mindegyik állófázis rendelkezik ionos vagy ionizálható résszel (amino- és/vagy karboxilcsoportok), amelyek elsősorban az ionos vegyületek elválasztásakor segíthetik az enantiomerek megkülönböztetését. Amennyiben cukor egységek is jelen vannak a szelektor szerkezetében, H-kötések alakulhatnak ki, illetve térbeli elhelyezkedésüktől függően 
sztérikus hatásokkal befolyásolhatják kedvezően vagy épp gátolva a királis felismerést. Végül, de nem utolsó sorban azt is érdemes szem előtt tartani, hogy a glikopeptidek RP körülmények között kosárszerkezetet vehetnek fel, ezáltal zárványkomplex képződése sem kizárt a királis felismerés folyamata során, hasonlóan a ciklodextrin alapú állófázisokhoz. A szelektorok szerkezeti hasonlóságából fakadóan a makrociklusos glikopeptidek kromatográfiás szempontból bizonyos mértékig komplementerként viselkednek, azaz ha egy glikopeptid alapú állófázis használata során részleges elválasztás figyelhető meg, egy másik glikopeptid alkalmazása révén sok esetben az enantiomerek hatékonyabb vagy akár alapvonalra történő elválasztása is megvalósítható [26]. A vizsgálandó vegyület és az alkalmazott szelektor között kialakuló lehetséges kölcsönhatások természetesen eltérő minőségűek és erősségűek lesznek a különböző mozgófázisok alkalmazásakor. A makrociklusos glikopeptid alapú királis állófázisok ezen előnyös tulajdonságát kihasználva egyazon oszlop használata során a mozgófázis összetételének változtatásával a királis felismerés mechanizmusa hangolható, amely újabb lehetőséget kínál a hatékonyabb elválasztásra. A vankomicin, teikoplanin és teikoplanin aglikon, illetve a risztocetin A alapú királis állófázisok napjainkban Chirobiotic $^{T M} V, T, T A G$ és $R$ márkanéven szerezhetők be a Sigma-Aldrich gyártótól. A Chirobiotic ${ }^{T M} V$ és $T$ oszlopok korábbi változatai Chirobiotic $^{T M}$ $V 1$ és $T 1$ néven, míg újabb típusai Chirobiotic ${ }^{T M} V 2$ és $T 2$ néven fordulnak elö, amelyek a hordozó lefedettségében (azaz a hordozón rögzített szelektor molekulák számában) és az állófázishoz kémiai kötést biztosító “spacer” (kar) hosszában különböznek egymástól [27]. A következőkben a leggyakrabban alkalmazott Chirobiotic $^{T M}$ állófázisok szerkezeti jellemzöit mutatom be röviden.

\section{Vankomicin}

A vankomicin volt az első kereskedelmi forgalomba kerülő makrociklusos glikopeptid alapú HPLC oszlop. Ma a vankomicin alapú királis állófázisokkal Chirobiotic $^{T M}$ $V$ és Chirobiotic ${ }^{T M} V 2$ néven találkozhatunk. A természetes vankomicin a Streptomyces orientalis baktérium által előállított amfoter glikopeptid, melynek tömege $1449 \mathrm{~g} / \mathrm{mol}$ [20]. Poláris karakterére utal, hogy alkoholban kevésbé, míg vízben jól oldódik. A makrociklusos gyürük által létrehozott belső, apoláris jellegű üregeket öt aromás gyürüs szerkezet hidalja át. Az így kialakított kosárszerü szerkezeti egységnek tulajdonítható a hidrofób-hidrofób kölcsönhatások létrejötte, valamint a királis felismerést olykor jelentős mértékben befolyásoló sztérikus hatások is. Utóbbiban a vankomicin szerkezetében fellelhető két cukorrész is közreműködik. A vankomicin alapú királis állófázisok igen sikeresnek 
bizonyultak a királis kromatográfia területén, kiváltképp természetes molekulák, amidok, savak, észterek és ciklusos aminok elválasztásában [20, 24, 28].

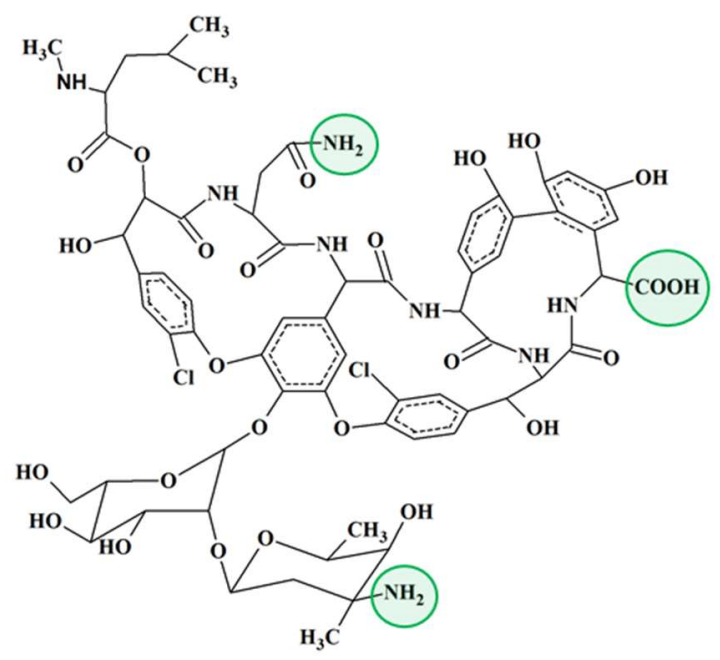

5. ábra A vankomicin szerkezete

\section{Teikoplanin és teikoplanin aglikon}

A makrociklusos glikopeptidek közül a Chirobiotic $^{T M} T$ oszlop szelektora, a teikoplanin volt a második az új antibiotikum alapú királis állófázisok sorában [29]. A teikoplanint az Actinoplanes teichommytecitus baktérium termeli és aktív az aerob, illetve anaerob Gram-pozitív baktériumok ellen [20]. Öt, szerkezetileg hasonló vegyület keverékeként fellelhető molekuláról van szó, amely több, figyelemre méltó szerkezeti tulajdonsággal rendelkezik. Az aglikon viszonylagosan merev kosárszerkezete négy makrociklus összekapcsolódásának eredménye. A makrociklusos gyürük hét aromás gyürüt tartalmaznak, melyek közül négy ionizálható fenolos jelleggel bír, két gyürün pedig klórszubsztituensek találhatók, melyek $\pi_{\mathrm{sav}}-\pi$-bázis kölcsönhatások kialakulásában játszhatnak fontos szerepet. Az aglikon egy primer aminocsoportot (pK 9,2) és egy karboxilcsoportot $(\mathrm{pK} \sim 2,5)$ is tartalmaz [30], melyek a fenolcsoportokkal együtt a molekula ikerionos szerkezetének kialakulásáért felelősek az RP folyadékkromatográfiás elválasztások során általánosan alkalmazott ideális $\mathrm{pH}=3,5-8,0$ tartományban. A teikoplanin három cukorrészt, többek között két $D$-glükózamint és egy $D$-mannózt is tartalmaz egy szubsztituált nonillánncal együtt, melyek a hidrofób-hidrofób kölcsönhatások kialakításában vehetnek részt. A cukoregységek eltérő módon befolyásolhatják a királis felismerést. Egyrészt sztérikusan gátolhatják a kosár belsejéhez történő hozzáférést, valamint megakadályozhatják a lehetséges kölcsönhatás kialakulását az aglikon két fenolos és egy alkoholos 
hidroxilcsoportjával, melyeken keresztül kapcsolódik a három cukoregység a természetes teikoplanin esetén. A királis felismerési folyamathoz kedvező módon is hozzájárulhatnak oly módon, hogy a rajtuk fellelhető alkoholos hidroxil-, éter- és amidcsoportok, illetve a nonillánc további kölcsönhatási lehetôségeket biztosít az elválasztani kívánt minta molekuláival $[18,20]$. A teikoplanin talán legegyedibb szerkezeti jellemzője, hogy az egyik glükózamin $N$-acil-szénhidrogénlánccal rendelkezik. E különleges szerkezeti tulajdonságból fakad, hogy a teikoplanin felületaktívabb, mint más rokon glikopeptidek. A Chirobiotic $^{T M} T$ oszlop egyedülálló szelektivitást nyújt számos vegyületcsalád számára. Eredményesen alkalmazható nem derivatizált $\alpha, \beta, \gamma$-, illetve ciklusos aminosavak, $N$-védett (Fmoc-, $Z$-, $B o c-)$ aminosav sztereoizomerek elválasztására. Ezen kívül javasolják még savas karakterü molekulák (pl. karbonsavak, fenolok), kisméretű peptidek, ciklusos amidok, szulfoxidok, valamint alifás és aromás aminok elválasztására is [19, 20, 28, 30-34]. Az eddig azonosított öt teikoplanin glikopeptid csupán a széndhidrogén lánc jellegében különbözik egymástól. A leggyakoribb teikoplaninnal teikoplanin- $\mathrm{A}_{2-2}$ néven találkozhatunk, melynek molekulatömege $1877 \mathrm{~g} / \mathrm{mol}[20]$.

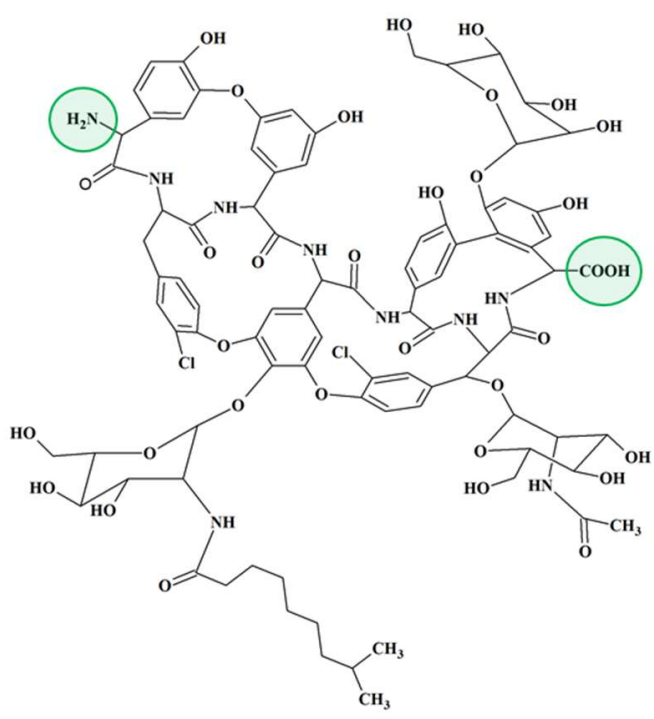

6. ábra A teikoplanin- $\mathrm{A}_{2-2}$ szerkezete

A korábbiakban ismertettem, hogy a szelektor cukorrésze nem minden esetben segíti elő a királis megkülönböztetést. A teikoplanin aglikon szerkezetét a cukoregységek eltávolításával, pontosabban azok hidrolízisével hozták létre, melynek köszönhetően ez a szelektor rendelkezik a legkisebb molekulatömeggel (1197 g/mol). Mivel a kémiai módosítás során a hidroxilcsoportok a cukoregyégek eltávolításával szabaddá váltak, az 
aglikon polárisabb a természetes teikoplaninnál. Berthod és munkatársai bebizonyították, hogy a kiralitáscentrumok számának csökkenése nem jár az elválasztóképesség hatékonyságának számottevő romlásával [35]. Az aglikon szelektorral ellátott királis állófázisok sikeresnek bizonyultak semleges sztereoizomerek elválasztására kizárólag szerves oldószert tartalmazó mozgófázisok alkalmazásával, PO módban. A további fejlesztések során az aglikont a hidroxilcsoportok metilezésével igyekeztek specifikusabbá tenni savas karakterű sztereoizomerek elválasztása céljából [36]. Az aglikon a Chirobiotic ${ }^{T M}$ $T A G$ oszlop szelektora, amely egyedülálló szelektivitást nyújt aminosavak és peptidek enantioszelektív elválasztására, de különböző semleges vegyületek, diazepinek, hidantoinok, oxazolidinonok, szulfoxidok elválasztására is javasolják [19, 20, 28, 31, 32, 34, 37].

\section{Risztocetin A}

A risztocetin A a Nocardia lurida fermentációs terméke [38], melyet 2066 g/mol molekulatömeg jellemez [20]. Antibiotikum révén nagyfokú aktivitással rendelkezik a Gram-pozitív baktériumokkal szemben, ideértve a többi antibiotikummal szemben rezisztens törzseket is $[39,40]$. A mukopeptidekben a $D$-Ala- $D$-Ala terminális szekvenciához való szelektív kötődés révén gátolja a baktériumsejtfal szintézisét [41, 42]. Az előzőekben tárgyalt makrociklusos glikopeptidekhez hasonlóan ennél a vegyületnél is megfigyelhető az aglikon rész jellegzetes kosárszerkezete, amelyet négy makrociklus hoz létre. A 38 kiralitáscentrummal rendelkező vegyület hét aromás gyürüt és hat cukor részt tartalmaz. Számottevő különbség a többi glikopeptiddel szemben a szabad karboxilcsoport hiánya. Helyette metilészter-csoport van jelen, amely gyengébb kölcsönhatást eredményezhet kationos jellegü vegyületek analízise során. A glikopeptid alapú makrociklusos antibiotikumok közül a risztocetin A a legpolárisabb szelektor 21 hidroxilcsoportjának, valamint a hidrofób lánc hiányának köszönhetően. Ez az amfoter vegyület savas és vizes közegben jól, míg semleges pH-n kevésbé oldódik [43]. 


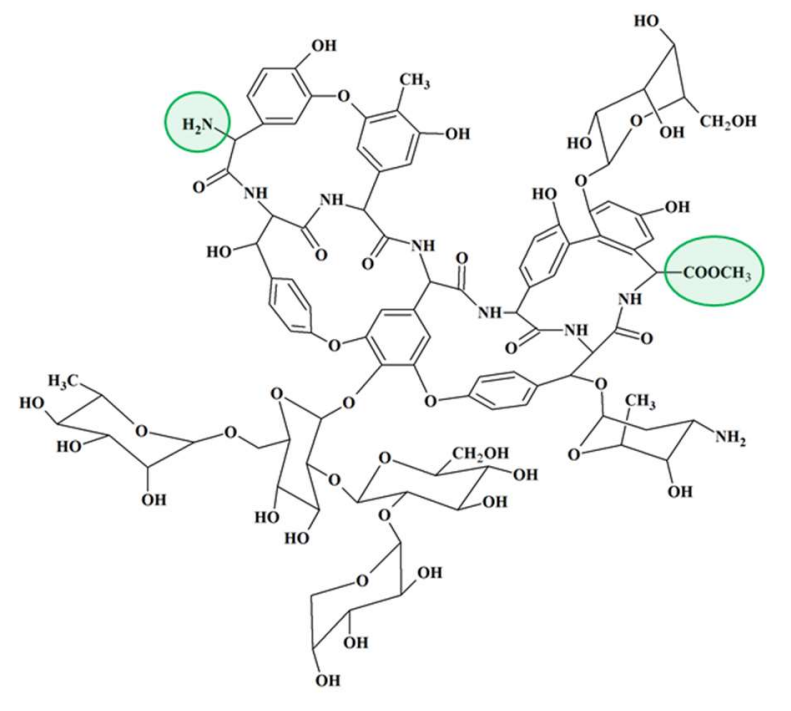

7. ábra A risztocetin A molekula szerkezeti képlete

A risztocetin A a Chirobiotic ${ }^{T M} R$ oszlop szelektora, s szerkezeti komplexitásának köszönhetően a vegyületek igen széles skálájának, többek között anionos királis molekulák, valamint különféle szubsztituált aminosavak elválasztására nyújt lehetőséget [20, 34, 44].

\subsubsection{Ioncserélő típusú állófázisok}

A királis ioncserélő típusú állófázisok a kétezres évek elején váltak kereskedelmi forgalomban is elérhetővé. A kinin $(Q N)$, valamint az úgynevezett pszeudoenantiomere, a kinidin $(Q D)$ a cinkóna alkaloidok legjelentősebb képviselői, melyek mint gazdaságosan kinyerhető természetes források, egyre inkább az érdeklődés középpontjába kerültek az állófázisok fejlesztése során. A pszeudoenantiomer kifejezés alatt azt értjük, hogy az említett két sztereoizomer egymással diasztereomer kapcsolatban áll, viszont a királis felismerés alkalmával gyakran enantiomerként viselkednek [45]. Kivételes szerkezeti tulajdonságaik (változatos funkciós csoportok megléte, s ezek kombinációja) révén igen széleskörüen alkalmazhatók az enantioszelektív elválasztások során.

A kinafa (Cinchona ladgeriana) kérgéből kivont cinkóna alkaloidok királis szelektorként történő sikeres alkalmazásáról először az 1950-es években közöltek eredményeket [46, 47]. Később, az 1980-as években Izumoto [48, 49], valamint Petterson és munkatársai [50-52] ionpár képzésén alapuló folyadékkromatográfiás módszereket dolgoztak ki savas karakterü vegyületek vizsgálatára. Az elért sikeres analízisekre támaszkodva 1987-ben Rosini és munkatársai szilikagélen rögzített kinin alapú állófázisok 
alkalmazásáról számoltak be. Munkájuk során alkil-aril-karbinolok, amidok, binaftil származékok, valamint egyéb gyógyszerészeti jelentőséggel bíró vegyületek királis elválasztását valósították meg [53]. Az ezt követő években számos kutatócsoport tűzte ki célul kinin és kinidin alapú állófázisok szintézisét, valamint ezen állófázisok alkalmazásával különféle vegyületek enantioszelektív elválasztását. A kísérletek során azonban hamar kiderült, hogy ezeknek az állófázisoknak kicsi az enantioszelektivitása, stabilitásuk pedig nem kielégítő, ennélfogva nem terjedtek el a kromatográfiás gyakorlatban.

Lindner és munkatársai évtizedek óta foglalkoznak cinkóna alkaloid alapú királis állófázisokkal. 1996-ban megjelent közleményükben áttörő eredményekről számoltak be. A természetes alkaloidok szekunder C9-es hidroxilcsoportját karbamoilcsoportra cserélték, s ezáltal elérték, hogy a gyenge anioncserélő (WAX) típusú állófázis jelentősebb enantiomerfelismerő-képességgel rendelkezzen [45]. Az ily módon kifejlesztett anioncserélő oszlopok 2002-ben kerültek kereskedelmi forgalomba, majd 2005-től Chiralpak $^{\circledR} Q N-A X$ és $Q D-A X$ néven szerezhetők be a Chiral Technologies Europe-tól. Az anioncserélő szelektorok fejlesztésének sikerein felbuzdulva sikerült megalkotni a kationcserélő állófázisokat oly módon, hogy aminociklohexán-szulfonsav alapú csoportot rögzítettek a szilikagél hordozóhoz [54], majd a rögzítés módját továbbfejlesztve jutottak el az erős kationcserélő (SCX) típusú állófázisok létrehozásáig [55].

A fentebb említésre került anioncserélő szerkezetének további módosítása során Lindner és munkatársai a cinkóna alapvázhoz a C9-es szénatomra egy transz-2aminociklohexán-szulfonsav (ACHSA) csoportot kötöttek karbamát kötésen keresztül. Így valósult meg egy olyan kombinált állófázis kialakítása, melynek alkalmazásával egyidejűleg ionpár képződésére nyílik lehetőség [56]. A $Q N$ vagy $Q D$ és $(R, R)$ - vagy $(S, S)$ aminociklohexán-szulfonsav különféle párosításával négyféle szelektor kialakítása valósítható meg (8. ábra). Ezen ikerionos, anion- és kationcserélő tulajdonsággal egyaránt rendelkező királis oszlopok közül a $Q N$ és $(S, S)$-ACHSA, valamint a $Q D$ és $(R, R)$-ACHSA egységekből felépülő szelektorokat tartalmazó állófázisokat (Chiralpak ${ }^{\circledR} Z W I X(+)$ és $Z W I X(-))$ a Daicel Corporation forgalmazza. A másik két típus, a $Z W I X(+A)(Q N$ és $(R, R)$ ACHSA) és a $Z W I X(-A)$ ( $Q D$ és $(S, S)$-ACHSA) kereskedelmi forgalomban még nem elérhető változatai az ikerionos állófázisoknak. 


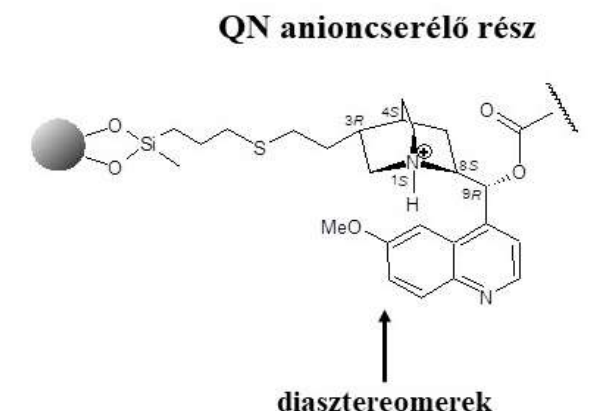
(pszeudoenantiomerek)

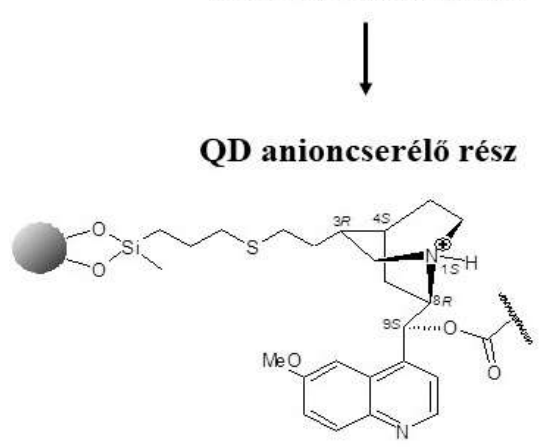

\section{ACHSA kationcserélő rész}

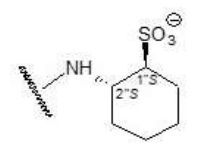

ZWIX(+)

QN $(8 S, 9 R)$ ACHSA (1"S, 2"S)

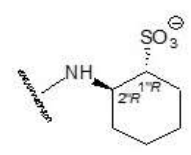

ZWIX(+A)

$\mathrm{QN}(8 S, 9 R)$ ACHSA $(1 " R, 2 " R)$
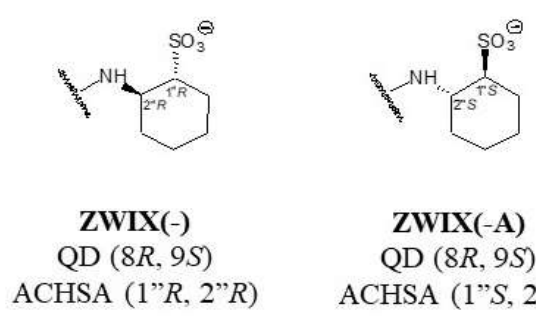

ZWIX(-A)

QD $(8 R, 9 S)$ ACHSA (1" $S, 2 " S)$

8. ábra Az ikerionos állófázisok általános szerkezeti sémája

Az ioncserén alapuló állófázisok esetén a retenciós mechnizmusban az ionos kölcsönhatások kiemelkedően fontos szereppel bírnak, melyek a szelektor, illetve a vizsgált vegyület töltéssel rendelkező funkciós csoportjai között jöhetnek létre. Amint azt korábban említettem, az ikerionos típusú állófázisok alkalmazása révén mindkét ioncsere folyamat egy időben játszódhat le. A szelektor tercier amin része (gyenge anioncserélö), illetve szulfonsav része (erős kationcserélő) és az elválasztani kívánt vegyület töltéssel rendelkező funkciós csoportjai között kialakuló elektrosztatikus kölcsönhatások meghatározó szerepet töltenek be a királis felismerésben.

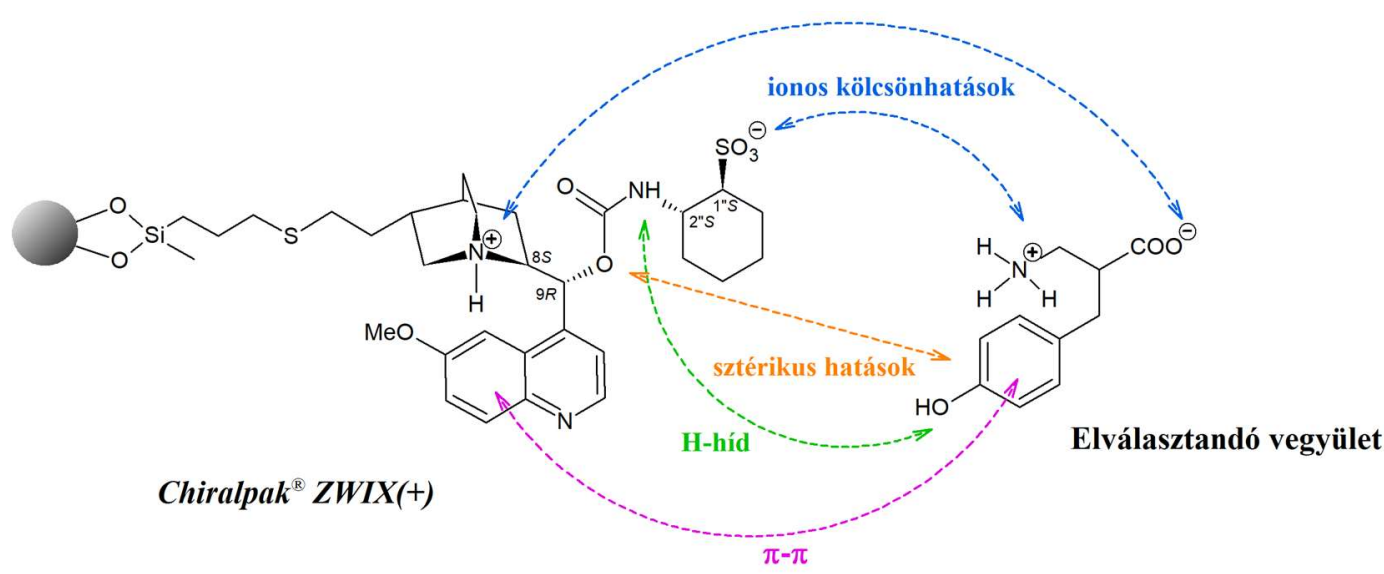

9. ábra Lehetséges kölcsönhatások ikerionos típusú állófázisok esetén 
Ahogyan azt a 9. ábra is szemlélteti, az ilyen típusú állófázisok alkalmazásakor az ionos kölcsönhatások mellett H-híd, $\pi-\pi$ és van der Waals kölcsönhatások segíthetik elő a királis felismerést. Ezen másodlagos kölcsönhatások mellett sztérikus hatások befolyásolhatják az enantiomerek megkülönböztetését. Annak érdekében, hogy a szelektor és az elválasztani kívánt vegyületek megfelelő töltéssel rendelkezzenek, sav és bázis módosítókat szükséges a mozgófázishoz adagolni. Az ikerionos állófázisok hatékony megoldást nyújtanak különböző királis savak, aminok, aminosavak és peptidek királis megkülönböztetésére [57-59]. Fontosnak tartom megemlíteni, hogy vízmentes eluensben a poláris szerves oldószerek alkalmazása a legelterjedtebb a cinkóna alkaloid alapú ikerionos oszlopok esetén. A $\mathrm{MeOH}$ protikus oldószer révén jelentősen csökkentheti a H-híd kialakulásának esélyét az állófázis szelektorával, illetve a mintát jobban szolvatálva visszaszoríthatja az ionos kölcsönhatásokat. Az aprotikus MeCN viszont elősegíti az ionos, s nagymértékben befolyásolja a $\pi-\pi$ kölcsönhatások kialakulását. A két oldószer ily módon komplementerként viselkedik, azaz $\mathrm{MeOH} / \mathrm{MeCN}$ különböző arányú oldószerelegyek alkalmazásával a kromatográfiás tulajdonságok (mint a visszatartás, szelektivitás) könnyen hangolhatók ikerionos állófázisok alkalmazása során [59].

\subsubsection{Módosított poliszacharid alapú állófázisok}

A poliszacharidok jól definiált szerkezettel rendelkező királis biopolimerek. Előnyös tulajdonságaiknak köszönhetően régóta alkalmazzák őket kromatográfiás célokra. A poliszacharidok hasznosíthatósága racém elegyek elválasztására egészen 1951-ig nyúlik vissza, amikor Kotake és munkatársai aminosavak elválasztását valósították meg cellulóz alapú állófázison papírkromatográfiával [60]. Tíz évvel később szintén cellulóz segítségével hajtották végre királis katechinek elválasztását oszlopkromatográfia segítségével [61]. A legelső gyakorlati tapasztalatok azt mutatták, hogy a természetes di-, oligo- és poliszacharidok csak korlátozott mértékben használhatók enantiomerek megkülönböztetésére, így az 1960-as évektől kezdve különböző cellulóz származékokat alkalmaztak a hatékonyabb elválasztások reményében. 1967-ben Lüttringhaus, Hess és Rosenbaum részlegesen acetilezett cellulózzal, 1973-ban pedig Hesse és Hagel mikrokristályos cellulóz-triacetáttal végzett sikeres elválasztásokról számoltak be [62, 63]. Ezek a hordozó nélküli állófázisok elméletileg nagy mintakapacitást és hatékony elválasztást tettek lehetővé, viszont mechanikai stabilitásukat és a felhasználható oldószerek körét növelni kellett annak érdekében, hogy szélesebb körben is alkalmazhatóvá váljanak. Ezt a 
mechanikai stabilitással kapcsolatos problémát Okamoto és munkatársai sikeresen megoldották. 1984-ben megjelent közleményükben makropórusos szilikagélen rögzített cellulózszármazékokkal végzett enantioszelektív elválasztásokat ismertettek [64]. Az 1990es évektől kezdve a poliszacharid alapú királis állófázisok fejlesztése intenzív kutatási területté forrta ki magát [65-67], melynek köszönhetően kereskedelmi forgalomban is elérhetővé váltak a megfelelő mechanikai stabilitással és hatékony enantioszelektivitással rendelkező oszlopok. Kedvező tulajdonságaikból (megnövelt mechanikai stabilitás, kompatibilis oldószerek szélesebb köre) adódóan napjainkban a leggyakrabban alkalmazott királis állófázisokról beszélhetünk. Ezek az állófázis típusok eredményesen alkalmazhatók főleg aromás, valamint semleges (ritkábban savas és bázikus karakterü) molekulák elválasztására egyaránt [68-71].

A poliszacharid típusú vegyületek több képviselője is használható királis állófázisként, úgy mint a cellulóz, amilóz, inulin, xilán, kurdlán, kitozán és dextrán [64]. Ezen vegyületek közül a legjobb eredményeket cellulóz és amilóz alapú karbamát- és észterszármazékokkal érték el [70]. A polimerlánc $D$-glükózegységekböl épül fel, amelyek cellulóz esetén $1 \beta-4$, amilóz esetén pedig $1 \alpha-4$ glikozidos kötéssel kapcsolódnak egymáshoz. A glükóz egységek három szénatomján fellelhető OH-csoportokat módosítva karbamát- és észtercsoportokat építettek be a molekulákba, melynek köszönhetően a természetes poliszacharid alapú állófázisoknál hatékonyabb, különböző kölcsönhatások kialakítására képes szelektorokhoz jutottak. A fejlesztések következő szakaszában a poliszacharid származék aromás gyürüjén fellelhető szubsztituensek minőségének és helyzetének optimalizálására fordítottak különös figyelmet [72]. A cellulóz alapú trisz-3,5-dimetilfenilkarbamát szelektorral rendelkező Chiralcel $O D$ oszlop szabadalmi lejáratát követően nagymértékű piaci verseny vette kezdetét, melynek következtében napjainkban számos, elméletileg ugyanazzal a szelektorral rendelkező királis állófázis érhető el kereskedelmi forgalomban. Beesley szerint a poliszacharid típusú állófázisok történetének ezen időszaka a "klónok éve" volt [73]. Példának okáért a Kromasil CelluCoat (Akzo Nobel), a RegisCell (Regis Technologies), a Reprosil OM (Dr. Maisch) és a Lux Cellulose-1 (Phenomenex) olyan fizikailag kötött cellulóz alapú királis állófázisok, melyek ugyanazzal a királis szelektorral rendelkeznek, mint a Chiralcel $O D$ oszlop. Fontos azonban megemlíteni, hogy ezek az állófázisok gyártótól függően jelentősen különbözhetnek a hordozó szilikagél minőségében, az állófázishoz való rögzítés módjában, valamint a cellulóz lánc polimerizációs fokában, ennélfogva a szelektivitásukban is számottevő különbségek mutatkozhatnak meg. 
Amennyiben a polimerek csak fizikailag kötöttek az állófázis felületén, a hordozó lemosásának lehetősége miatt az alkalmazható oldószerek köre korlátozott. Ez azt jelenti, hogy azon oldószerek, melyek duzzasztják vagy oldják a polimert, nem használhatók. Ezen állófázisok esetén a gyártói ajánlásoknak megfelelően érdemes NP kromatográfiás körülmények között dolgozni, tehát alapoldószerként hexán vagy heptán, illetve a visszatartás optimalizálására alkalmazott alkoholok (pl. propán-2-ol) bizonyos arányú elegye általában megfelelő választás kiindulási mozgófázisként az analízis során. Nagymértékü előrelépést hozott magával 2004-ben a Daicel cég által kereskedelmi forgalomban megjelent Chiralpak IB oszlop. Ezen állófázis esetén a 3,5-dimetilfenilkarbamát szelektort egy fotokémiai folyamat révén kovalensen kötötték a szilikagél hordozóhoz. Erre az úgynevezett immobilizált állófázisra már a fentebb említett oldószer korlátozás kevésbé szigorú, hiszen a kémiailag kötött szelektort már nem lehet "lemosni” a hordozóról, azaz a mozgófázisként szóba jöhető oldószerek minőségét sikerült kiterjeszteni "nem-standard” oldószerekre is (pl. tetrahidrofurán, kloroform, diklór-metán, dioxán, stb.). Ezek az állófázisok már RP rendszerekben is alkalmazhatók, azonban használatuk során tisztában kell lennünk vele, hogy a kromatográfiás módok váltogatása az alkalmazott oszlop hatékonyságának csökkenését eredményezheti. További hátrányként megemlíthető, hogy a kémiailag kötött állófázisok királis felismerőképessége általában kisebb, mint a fizikailag kötött állófázisoké, mivel a szelektor rögzítése során bekövetkezhet a sztereospecifikus konformáció módosulása $[74,75]$.

A poliszacharidok döntően királis vegyületek aszimmetrikus szerkezetükből adódóan. Ez az aszimmetria több szinten is megmutatkozik, más szóval a polimerek sztereoszelektivitása három fő szerkezeti tulajdonságukra vezethető vissza:

1. a glükózcsoportokon található kiralitáscentrumok hatása - molekuláris kiralitás;

2. a szénhidrátlánc egyedi konformációs szerkezetének (cellulóz esetén merev lineáris, míg amilóz esetén helikális) hatása - konformációs kiralitás;

3. a szomszédos polimerláncok királis rendezettségének hatása - szupramolekuláris kiralitás [76].

Az enantiomerfelismerő-képesség alapját a poliszacharid alapú állófázisok esetében a szelektor, valamint az elválasztani kívánt vegyület között létrejövő H-híd, dipólus-dipólus és $\pi-\pi$ kölcsönhatások képezhetik $[77,78]$. Ezen kölcsönhatások mellett lényeges szerepet tölthetnek be a merevebb, nagy térkitöltésű aromás gyürük jelenléte miatt fellépő sztérikus hatások is, melyek gátolhatják a kötési oldal hozzáférhetőségét. Az említett kölcsönhatások 
közül a $\pi-\pi$ kölcsönhatás a legtöbb királis állófázis esetén döntő mértékben járul hozzá a királis felismerés folyamatához. Amennyiben az aromás részen szubsztituensként elektronküldő vagy elektronhiánnyal rendelkező funkciós csoport található, a szelektor és az elválasztandó molekula aromás gyürüi között kölcsönhatás léphet fel. Az elektronhiányos szelektormolekulát a Lewis féle sav-bázis elmélet szerint nevezhetjük Lewis-savnak, míg az elektron donort Lewis-bázisnak. A vizsgálandó vegyületeknél általában az aromás gyürü vagy elektronhiányos, vagy pedig elektrontöbblettel rendelkezik. Ennek értelmében egy elektronhiányos aromás rész és egy elektrontöbblettel bíró enantiomer között $\pi_{\mathrm{sav}}-\pi_{\mathrm{bázis}}$ kölcsönhatás jön létre és fordítva. Mindemellett jelentős szerepet töltenek be a karbamát- és észtercsoportok is a molekula-komplex stabilizálásában, továbbá a fentebb ismertetett $\pi-\pi$ kölcsönhatás erősítésében. 
1. táblázat Az alkalmazott cellulóz és amilóz alapú állófázisok szelektorai

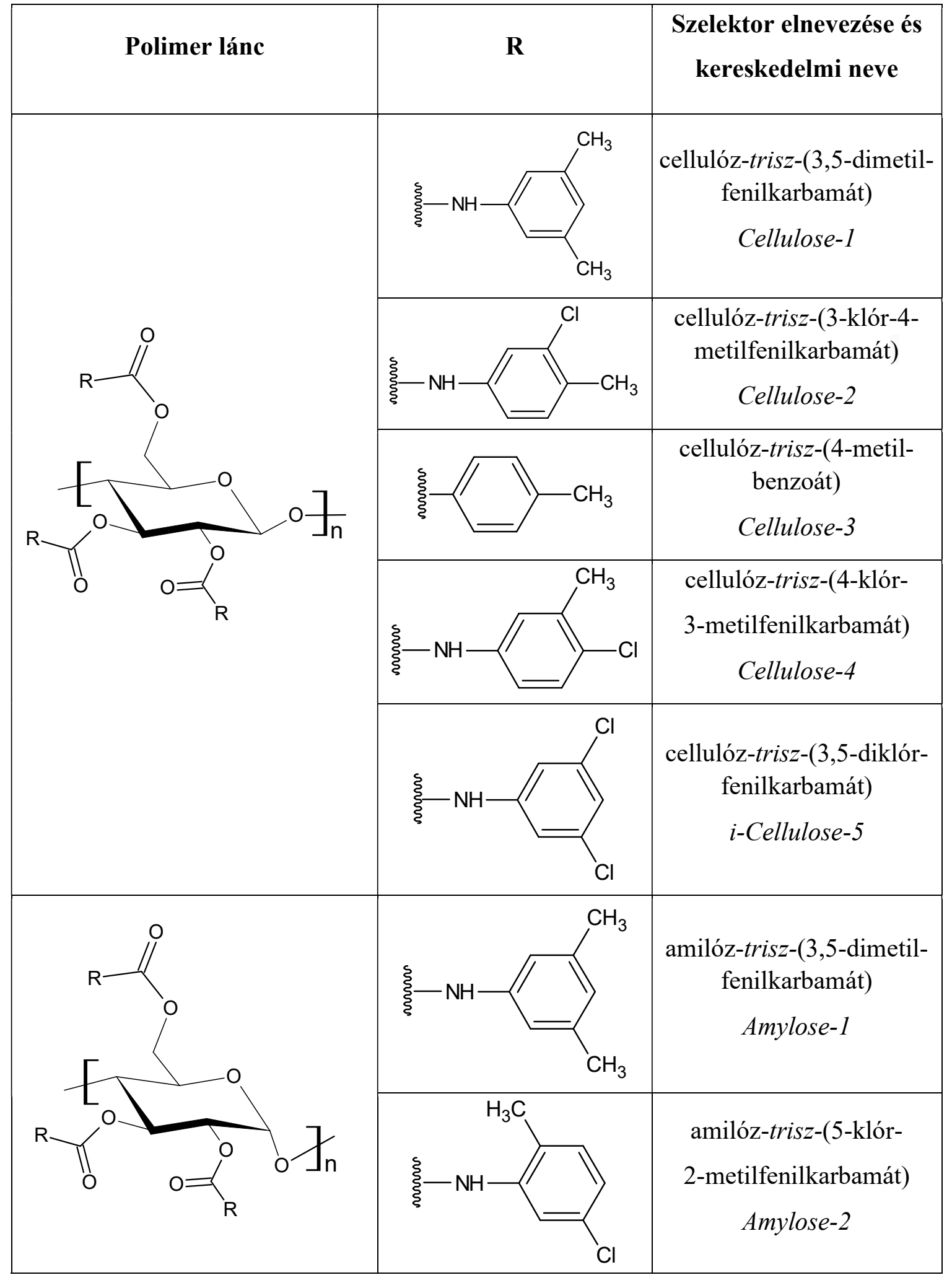




\subsection{Szuperkritikus állapotban (vagy annak közelében) levő eluens alkalmazása enantioszelektív elválasztásokra}

Rendszerint négy féle halmazállapotot (szilárd, folyadék, gáz és plazma) szokás megkülönböztetni, azonban az anyagoknak létezik egy olyan meghatározott állapota, ami a kritikus hőmérséklete $\left(\mathrm{T}_{\mathrm{k}}\right)$ és kritikus nyomása $\left(\mathrm{p}_{\mathrm{k}}\right)$ felett van (10. ábra). Ezt nevezzük úgynevezett szuperkritikus állapotnak, ahol az anyagok bizonyos tulajdonságai részben a folyadékokéra (sürüség), részben a gázokéra (viszkozitás) emlékeztet, de előfordulnak olyan jellemzők is (diffúziós állandó), amelyek a gáz- és folyadék halmazállapot között helyezkednek el [79]. Már régóta ismeretes, hogy a szuperkritikus állapotban levő anyagok kiválóan felhasználhatók különböző kémiai eljárásokban, pl. oldószerként extrakció során. Az elválasztástechnikában a szuperkritikus állapotú (vagy annak közelében levő) eluens mozgófázisként történő alkalmazhatóságának felismerése tette lehetővé egy újabb kromatográfiás technika megszületését. Mivel a technika pontos elnevezéséről máig tudományos vita folyik a kutatói közösségben, értekezésemben ezt a módszert a továbbiakban szuperkritikus folyadékkromatográfiának (SFC) fogom nevezni.

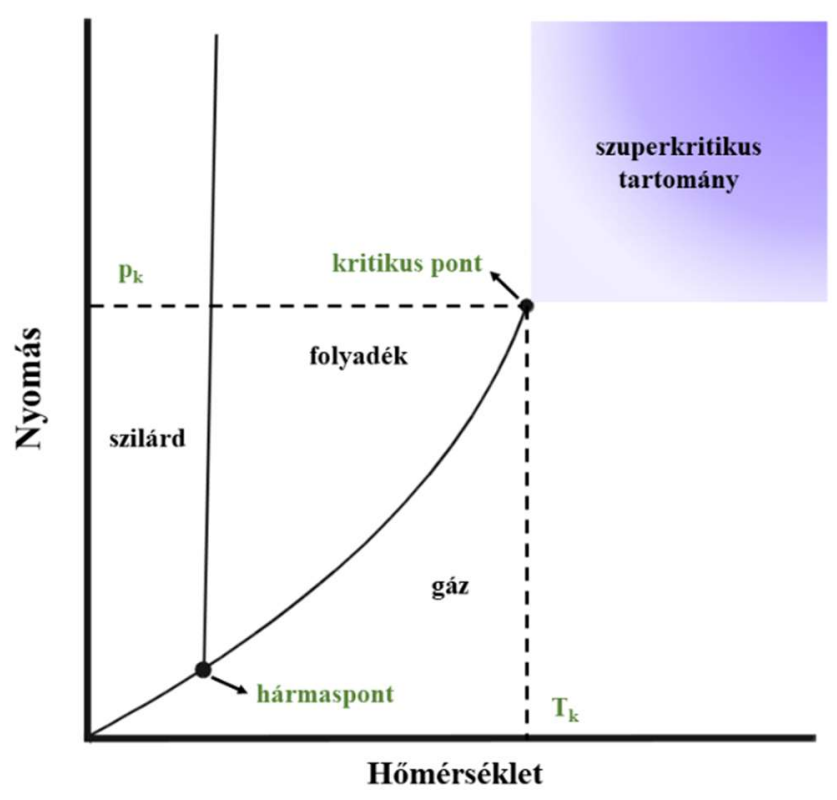

10. ábra Szuperkritikus állapotot szemléltető fázisdiagram [80]

A szuperkritikus állapot kromatográfiás célú használata közel hatvan évvel ezelőttre vezethető vissza. Klesper és munkatársai 1962-ben megjelent közleményükben mutatták be hőstabil porfirinszármazékok eredményes elválasztását szuperkritikus klór-fluor-metán alkalmazásával. Módszerüket nagynyomású gázkromatográfiaként definiálták [81]. Az SFC 
fejlődése a HPLC rendkívül gyors térhódítása miatt sokáig háttérbe szorult. Az 1980-as évekre felismerték a technikában rejlő lehetőségeket, melynek következtében egyre nagyobb figyelem irányult az SFC fejlesztésére. Gere és munkatársai egy Hewlett-Packard 1084B folyadékkromatográfiás rendszert alakítottak át, melynek köszönhetően lehetővé vált szuperkritikus állapotú szén-dioxid eluensként való alkalmazása folyadékkromatográffal [82]. Saito 2012-es összefoglaló munkájában mélyreható áttekintést nyerhetünk az SFC müszeres fejlődéséről a kapilláris SFC-től egészen a modern töltetes állófázisok alkalmazásáig [79]. 2013-ban a Waters cég egy új SFC készüléket hozott forgalomba UPC ${ }^{2}$ (Ultra Performance Convergence Chromatography) néven, amely a modern müszeres analitika egy újabb dimenzióját nyitotta meg a kutató szakemberek elött. Napjainkban a legelterjedtebb technika az SFC mérések kivitelezésére az úgynevezett töltetes SFC, azaz HPLC oszlopok alkalmazása. Létezik néhány SFC-specifikus állófázis kereskedelmi forgalomban, de az SFC-ben használt állófázisok lényegében teljesen megegyeznek a HPLC gyakorlata során alkalmazott oszlopokkal (kivételt képeznek ez alól az immobilizált fehérje alapú királis állófázisok).

HPLC

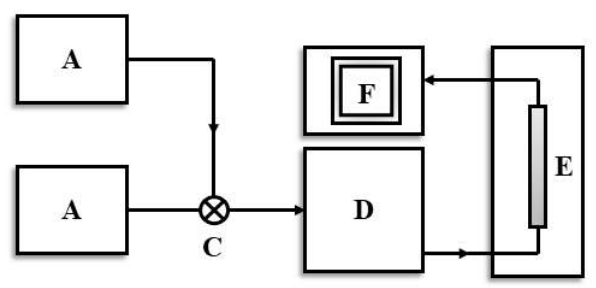

SFC

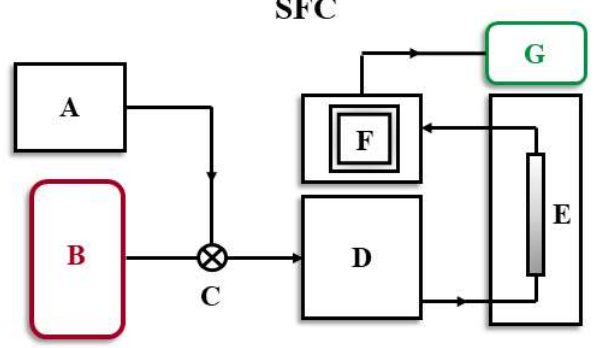

A, Folyadékpumpa

B, Szén-dioxid pumpa

C, Keverö

D, Mintabeviteli rendszer

E, Kolonnatermosztát

F, Detektor

G, Nyomásszabályozó

11. ábra A HPLC és az SFC müszeres elrendezésének összehasonlítása

Az SFC technikai kivitelezésére a HPLC-vel analóg módon kialakított kromatográf készülék szolgál (11. ábra). A különbség abban rejlik, hogy az SFC készüléknél szükségünk van egy szén-dioxid pumpára, valamint egy nyomásszabályozóra. Utóbbi feladata az alkalmazott mozgófázis szuperkritikus (vagy ahhoz közeli) állapotban tartása. Elvileg 
többféle anyag szolgálhat eluensként az SFC-ben, számos előnyös tulajdonságából (kémiai inertség, alacsony kritikus hömérséklet $\left(\mathrm{T}_{\mathrm{k}}=304,14 \mathrm{~K}\right)$ és kritikus nyomás ( $\mathrm{p}_{\mathrm{k}}=73,773$ bar), megfelelő tisztaság, költséghatékonyság, hangolható polaritás szerves adalékokkal) fakadóan ma a szén-dioxid a legkedveltebb mozgófázis-alkotó. Itt fontosnak tartom megjegyezni, hogy a gyakorlatban szinte minden esetben oldószerkeverékeket alkalmazunk mozgófázisként. Mivel a tiszta szén-dioxid apoláris, önmagában alkalmazva a polárisabb molekulákat nem oldaná, így különféle szerves módosítókkal, többek között kis szénatomszámú alkoholokkal (pl. metanol, etanol, propán-2-ol, stb.), illetve a HPLC technikánál megszokott oldószerekkel (pl. acetonitril) növelhető a polaritása. Természetesen alapvető elvárás az alkalmazott módosítóval szemben, hogy elegyedjen a szén-dioxiddal, így elkerülhető az esetleges fáziszétválás [83]. Mivel kis mennyiségü (általában 2-25\%) a szerves oldószer felhasználás, az SFC “zöld”, azaz környezetbarát elválasztástechnikai módszernek tekinthető, melynek főként a félpreparatív és preparatív elválasztások esetén van nagy jelentősége [80].

A szuperkritikus állapotú eluens használata számos előnyt hordoz magában. Egyrészt a folyadékokénál kisebb viszkozitást, másrészt nagyobb diffúziós állandót eredményez, melyből adódóan kisebb lesz a kialakuló nyomás, valamint gyorsabb és hatékonyabb elválasztás érhető el. A kritikus értékek ( $T_{k}$ és $p_{k}$ ) alakulása nagymértékben függ a mozgófázis összetételétől, azaz a szén-dioxidhoz hozzáadott módosítók mennyiségétől és minőségétől. Rendszerint ezek az értékek növekednek az eluenshez hozzáadott módosítók hatására, melyeket úgy kell megválasztani, hogy a szén-dioxiddal való elegyedés fenntartható legyen, ezáltal elkerülhető a fázisszétválás jelensége [84]. Az eddigieket összefoglalva a töltetes SFC legnagyobb előnyei egyértelmüen megfogalmazhatók:

^ a mozgófázis viszkozitása kisebb, mint a folyadékoké, ebből adódóan a kialakuló gyorsabb molekuláris diffúzió következtében keskenyebb kromatográfiás csúcsokat kapunk,

^ a kis viszkozitás lehetővé teszi a nagy áramlási sebességek alkalmazását anélkül, hogy a kinetikai hatékonyság csökkenne,

^ a mozgófázisként használt szén-dioxid kémiailag inert, környezetbarát “oldószer”, melynek polaritása szerves módosítók alkalmazásával könnyedén szabályozható,

^ az oszlopok sorba kapcsolásával bonyolultabb elválasztások is megvalósíthatók,

$\star$ a HPLC alkalmazások SFC módszerekre is átültethetők [85]. 
Jelenleg a modern SFC alkalmazási területe egyre kiterjedtebb a technika sokszínüségének köszönhetően. A preparatív és királis elválasztásokon túlmenően a gyógyszeripari kutató és minőségellenőrző laboratóriumokban is egyre elfogadottabb kromatográfiás technikának bizonyul.

\subsection{A kromatográfiás elválasztás hőmérsékletfüggése és termodinamikai háttere}

A királis elválasztások sok esetben jelentősebb hőmérsékletfüggést mutatnak az akirális állófázisokhoz képest, melynek tanulmányozása a retenció mechanizmusának mélyebb megértésében nyújthat segítséget. A hőmérséklet növekedésével az alkalmazott mozgófázis viszkozitása csökken, valamint nő az oldott anyag diffúziós állandója. Ennek köszönhetően a mozgó- és állófázis közötti anyagátadási folyamatok nagyobb sebességgel játszódnak le, ezáltal az elválasztás kinetikai hatékonysága nő [86, 87]. Ezen kinetikai hatás mellett számolnunk kell egy termodinamikai hatással is, mely a szelektivitás változásában mutatkozik meg. Általában a hőmérséklet emelésével csökkenő enantioszelektivitást tapasztalhatunk, hiszen a megoszlási hányados hőmérsékletfüggő, így a két fázis közötti megoszlást kísérő szabadentalpia-változásra is hatással van a hőmérséklet változtatása [88].

$\mathrm{Az}$ egyensúlyi folyamatok standard szadabentalpia változása megadható az egyensúlyi állandóval (mely kromatográfiás retenció esetén megfeleltethető a megoszlási hányadossal),

$-\Delta G^{0}=R T \ln K$

ahol $\Delta G^{0}$ a standard szabadentalpia-változás, $R$ az egyetemes gázállandó, míg $K$ az egyensúlyi állandó.

A standard szabadentalpia-változás definíciója a Gibbs-Helmholtz összefüggésből ismert:

$\Delta G^{0}=\Delta H^{0}-T \Delta S^{0}$

ahol $\Delta H^{0}$ a standard entalpiaváltozás, míg $\Delta S^{0}$ a standard entrópiaváltozás.

Az (1) és (2) egyenletek összevonásával az alábbi összefüggéshez jutunk:

$$
\ln K=-\left(\frac{\Delta H^{0}}{R T}-\frac{\Delta S^{0}}{R}\right)=-\frac{\Delta H^{0}}{R T}+\frac{\Delta S^{0}}{R}
$$

A retenciós tényező $(k)$ az egyensúlyi állandó és a fázisarány szorzataként definiálható, miszerint: 


$$
k=K \phi=K \frac{V_{s}}{V_{m}}
$$

ahol $\phi$ a fázisarány, $V_{s}$ az állófázis térfogata, $V_{m}$ pedig a mozgófázis térfogata az oszlopon. Ha a (4) összefüggést a (3) egyenletbe behelyettesítjük, az úgynevezett van't Hoff egyenlet kromatográfiában alkalmazott általános alakjához jutunk:

$\ln k=-\frac{\Delta H^{0}}{R T}+\frac{\Delta S^{0}}{R}+\ln \phi$

Ezen megközelítéssel $\ln k$ értékét $1 / T$ függvényében ábrázolva az egyenes meredeksége $-\Delta H^{0} / R$, míg tengelymetszete $\Delta S^{0} / R+\ln \phi$. Abban az esetben, ha az $\ln \phi$ tagot nem ismerjük, a tengelymetszet $R$-el szorzott értékét használjuk $\left(\Delta S^{0^{*}}=\left(\Delta S^{0}+R \ln \phi\right)\right.$. Fontosnak tartom megjegyezni, hogy HPLC oszlopok esetén az állófázis pontos térfogata nem ismert, hiszen a kolonna töltetének csak kis részét képezik a kölcsönhatásért felelős ligandumok, nagy része viszont az a szilikagél, amely az elválasztás folyamatában nem vesz részt. Ebből adódóan reális termodinamikai jellemzőket csak akkor tudunk meghatározni a retenció hőmérsékletfüggéséből, amennyiben független mérésekkel a fázisarány értéke megállapítható [89]. Azt sem szabad elfelejteni, hogy amennyiben az állófázison többféle kötőhely van, az egyes kötőhelyek retencióhoz való hozzájárulása eltérö lesz. Mivel a van 't Hoff-féle ábrázolás során logaritmikus értékekkel számolunk, elveszítjük azt az additivitást, mellyel az egyes kötőhelyek járulnak hozzá a retencióhoz. Királis elválasztások során a fázisaránnyal kapcsolatban említett probléma „kiküszöbölhető”, amennyiben a retenció helyett a szelektivitás logaritmusát ábrázoljuk a hőmérséklet reciproka függvényében.

Tehát a szelektivitás $(\alpha)$ definíciójának ismeretében, miszerint:

$\alpha=\frac{k_{2}}{k_{1}}$

ahol $k_{1}$ és $k_{2}$ az egymást követően eluálódó két enantiomer visszatartási tényezőjét jelöli, az (5) pontban bemutatott van 't Hoff összefüggés behelyettesítést és egyszerüsítést követően az alábbi formában is felírható:

$$
\ln \alpha=-\frac{\Delta\left(\Delta H^{o}\right)}{R T}+\frac{\Delta\left(\Delta S^{o}\right)}{R}
$$

Az egyenletben szereplö tagok közül $\Delta\left(\Delta H^{0}\right)=\Delta H^{0}{ }_{2}-\Delta H^{0}{ }_{1}$ a két enantiomer standard entalpiaváltozásának különbségét, $\Delta\left(\Delta S^{0}\right)=\Delta S^{0}{ }_{2}-\Delta S^{0}{ }_{1}$ pedig a két enantiomer standard 
entrópiaváltozásának különbségét jelenti. A (7) pontban felírt megközelítés alapján $\ln \alpha$-t $1 / \mathrm{T}$ függvényében ábrázolva egy $-\Delta\left(\Delta H^{0}\right) / R$ meredekségü, valamint $\Delta\left(\Delta S^{0}\right) / R$ tengelymetszetű egyenest kapunk, melyekkel az egyes enantiomerekre jellemző termodinamikai paraméterek különbségei megállapíthatók. A van't Hoff-féle megközelítés során megállapított termodinamikai adatok egyensúlyi rendszereket jellemeznek. Mivel a királis elválasztások eredendően heterogének, ez sok esetben nem feltétlen teljesül a kromatográfiás folyamatok dinamikus rendszereire, mindazonáltal segítséget nyújthatnak a különböző elválasztási folyamatok retenciós mechanizmusának értelmezésében.

Amennyiben azt feltételezzük, hogy a két enantiomer elválasztása ugyanolyan felismerési mechanizmus alapján történik, az entrópia és az entalpia hozzájárulása az adott enantiomerek szabadentalpia-változásához számottevően nem különbözik egymástól és a kettő arányával jellemezhető az elválasztás:

$$
Q=\frac{\Delta\left(\Delta H^{0}\right)}{T \Delta\left(\Delta S^{0}\right)}
$$

ahol $T$ egy referencia hőmérséklet ( $Q$ értékét közleményeimben és az értekezésemben 298 K-re határoztam meg). Amennyiben $Q$ abszolút értéke egynél nagyobb, az enantiomerek elválasztása entalpiavezérelt, ha pedig egynél kisebb, akkor entrópiavezérelt folyamatról beszélünk $[90,91]$. 


\subsection{A vizsgált vegyületek kémiai, biológiai és farmakológiai jelentősége}

\subsubsection{Monoterpénvázas vegyületek}

\subsubsection{Limonén alapú karbociklusos $\beta$-aminosavak}

Az elmúlt két évtizedben egyre inkább előtérbe került a karbociklusos $\beta$-aminosavak sokoldalú alkalmazhatóságának lehetősége mind a gyógyszerfejlesztések, mind az aszimmetrikus szintézisek szempontjából [92-94]. Ez egyrészt annak köszönhető, hogy már önmagukban, kismolekulákként is figyelemreméltó farmakológiai hatásokkal rendelkeznek, másrészt jóval összetettebb szerkezetü, biológiailag aktív vegyületek értékes királis építőköveiként is gyakran alkalmazzák őket. A monoterpén alapú $\beta$-aminosavak kiralitását elsősorban a természetes monoterpének kiralitás centrumai határozzák meg, amelyek kiváló kiindulási anyagok lehetnek különféle enantioszelektív átalakításokhoz [94]. Ezek az aliciklikus vagy biciklusos $\beta$-aminosavak három vagy több kiralitás centrummal is rendelkeznek, ezért mind az enantio-, mind a diasztereoszelektív szintézisek, valamint az epimer aminosavak analitikai meghatározása kulcsfontosságú feladattá vált napjainkra potenciális farmakológiai alkalmazhatóságuk céljából. A $\beta$-aminosav enantiomerek előállításának nagyfokú sztereoszelektivitást biztosító és elterjedten használt módja a lítiumamid típusú nukleofilek $\alpha, \beta$-telítetlen észterekre történő konjugált addíciója a szintetikus kémiában $[95,96]$.

Újabb, limonénvázas királis aminosav származékok sikeres szintézisét valósították meg Szakonyi és munkatársai akirális és királis lítium amidok (S)-terc-butil-perilláttal történő addíciójával [97]. Mivel ezen vegyületek biológiai és farmakológiai hatása jelentősen függ sztereokémiai tulajdonságaiktól, a limonén vázzal bíró karbociklusos $\beta$ aminosav származékok királis elválasztása fontos feladat.

\subsubsection{Biciklusos aminoalkoholok és aminodiolok}

Jelentős biológiai és farmakológiai tulajdonságaikból adódóan az 1,3aminoalkoholokra és az 1,3,5-, valamint az 1,3,6-aminodiolokra egyre nagyobb figyelem irányult az elmúlt évtizedben. Az 1,3-aminoalkoholok gyakran fellelhetők jelentős bioaktivitással rendelkező vegyületekben, ezáltal roppant széleskörű felhasználás jellemzi őket a gyógyszerkémia területén. Több képviselőjük gyógyszerként forgalomba került vegyület, mint például a tramadol, amely egy opioid típusú, analgetikus hatású fájdalomcsillapító. [98]. A vildagliptin - szintén 1,3-aminoalkohol vázzal rendelkező 
vegyület - egy orális DPP-4 inhibítor, melyet széles körben használnak antidiabetikus terápiák alkalmával [99]. A 3-amino-1,2-diolok nem csak összetett szerkezetü bioaktív molekulák építőelemeiként, hanem önmagukban is figyelemre méltó farmakológiai hatással bírnak, mivel kardiovaszkuláris, citosztatikus és antivirális aktivitással egyaránt rendelkeznek [100]. Az aminodiol-típusú Zankiren ${ }^{\circledR}$ és Enalkiren ${ }^{\circledR}$ kereskedelmi nevü renininhibítorok a renin gátlásával kifejtve terápiás hatásukat a magas vérnyomás (hipertenzió) kezelésében játszanak fontos szerepet [101]. Az aminodiolok antidepresszív hatással is rendelkeznek: az $(S, S)$-reboxetin több országban engedélyezett az unipoláris depresszió, figyelemhiányos hiperaktivitás-zavar, illetve pánikbetegség kezelésére [102]. E vegyületek népszerüségét tovább bizonyítja, hogy sokoldalúan felhasználhatók biológiailag aktív vegyületek (például az immunterápiában nagyértékü citoxazon) szintézisének kiindulási anyagaiként is [103].

Természetes, optikailag aktív monoterpéneket kiindulási anyagként enantiomertiszta katalizátorok előállítására alkalmaztak [104]. Az 1,3-aminoalkoholok és aminodiolok, valamint ezek heterociklusos származékai kollektíven alkalmazott vegyületek királis segédanyagként, illetve királis ligandumokként különböző enantioszelektív átalakításokban, például aldehidek aszimmetrikus alkilezésében szerves cinkvegyületek segítségével [105]. Mindemellett az aminoalkohol és aminodiol analógokról ismeretes, hogy heterociklusos vegyületek szintézisének értékes építőelemei. Az értekezésemben vizsgált új típusú, limonén alapú biciklusos 1,3-aminoalkoholokat és 1,3,5-, 1,3,6-aminodiolokat kereskedelmi forgalomban is elérhető (-)-(S)- és $(+)-(R)$-limonén vegyületekből szintetizálták [106]. Ezen vegyületek enantioszelektív elválasztására korábban kromatográfiás módszert nem dolgoztak ki.

\subsection{2. $N$-metilszubsztituált és amidált ciklusos $\beta$-aminosavak}

A ciklusos $\beta$-aminosavak és származékaik gyakran vizsgált vegyületek figyelemreméltó biológiai aktivitásuknak és a szintetikus kémiában kihasználható előnyös tulajdonságaiknak köszönhetően. Az $(1 R, 2 S)$-2-aminociklopentánkarbonsav, avagy a ciszpentacin a karbociklusos $\beta$-aminosavak legegyszerübb képviselöje [107], amely megtalálható néhány természetes vegyület, mint például az amipurimicin szerkezetében [108]. Az icofungipen [(1R,2S)-2-amino-4-metilénciklopentánkarbonsav] a természetben fellelhető ciszpentacin szintetikus úton előállított származéka. Ezek a vegyületek értékes gomba-, illetve baktériumellenes aktivitással rendelkeznek [109]. A ciklusos $\beta$-aminosavak 
kiemelkedő farmakológiai hatásukon túlmenően értékes építőelemként szolgálhatnak különféle bioaktivitással bíró vegyületek, illetve farmakológiai szempontból fontos különféle módosított peptidek szintéziséhez. Ezen vegyületcsalád képviselöi szintén alkalmazhatóak a heterociklusos [110, 111], valamint a kombinatorikus kémiában [112, 113].

Az elmúlt évtizedben $\beta$-aminosavak nagyhatékonyságú folyadékkromatográfiás vizsgálatával több kutatócsoport foglalkozott közvetett (királis származékképzők) és közvetlen módszereket (királis állófázisok) egyaránt alkalmazva. Számos közlemény született $N$-acil és $N$-aril-védett aminosav származékok enantioszelektív elválasztásával kapcsolatban, ellenben kevés olyan kutatásról számoltak be, melynek során $N$ metilszubsztituált származékokat tanulmányoztak. $N$-metilszubsztituált- $\alpha$-aminosavak ligandumcserén alapuló elválasztását Brückner és munkatársai végezték el [114]. Nmetilleucin, $N$-metilizoleucin, $N$-metilfenilalanin, $N$-metilglutamát és aszpartát enantioszelektív elválasztását királis származékképző alkalmazásával oldották meg Hess [115], évekkel később pedig Tsesarskaia és munkatársai [116]. $N$-metilleucin, 2,4dinitrofenil, illetve 3,5-dinitrobenzol származékok cinkóna alkaloid alapú királis állófázisokon való elválasztásáról is közöltek kutatási eredményeket [117, 118]. Piette és munkatársai nemvizes kapilláris elektroforézis technikát alkalmazva 3,5-dinitrobenzol- $\mathrm{N}$ metilleucin enantioszelektív elválasztását mutatták be 2002-ben megjelent közleményükben [119]. Annak ellenére, hogy az értekezésemben tanulmányozott $N$-metilszubsztituált és amidált ciklusos $\beta$-aminosavak biológiai és farmakológiai hatásai még nem teljesen tisztázottak, vizsgálatuk kiváló kindulási pontként szolgálhat a szerkezet-retenció összefüggések feltárásában enantioszelektív folyadékkromatográfiás rendszerek alkalmazása révén.

Az eddigi rövid irodalmi áttekintésekből kiderül, hogy az általunk tanulmányozott vegyületcsaládok a gyógyszerkutatások területén fontos szerepet töltenek be. Farmakológiai és biológiai hatásuk vizsgálatát megelőzően az enantiomertisztaság ellenőrzése céljából analízisük egyik lehetséges stratégiája nagyhatékonyságú folyadékkromatográfiás módszerek alkalmazása. 


\section{Kísérleti rész}

\subsection{Vizsgált vegyületek}

A vizsgált anyagok döntően szintetikus vegyületek voltak, melyeket együttmüködő partnereink állítottak elö. Szintézisük rövidített változatát eredeti közleményeinkben ismertettük, így a továbbiakban ennek tárgyalására nem térek ki külön. A három vizsgált vegyületcsalád szerkezeti képleteit a 12-13. ábrán, valamint a 2. táblázatban mutatom be.

\section{Monoterpénvázas vegyületek:}

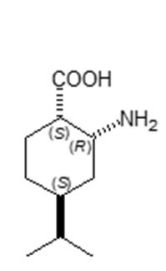

$1 \mathrm{~A}$
1<smiles>CC(C)C1CC[C@@H](O)[C@H](N)C1</smiles>

$1 B$

$(1 S, 2 R, 4 S) \quad(1 R, 2 S, 4 R)$
2<smiles>CC(C)c1ccc(C(=O)O)c(N)c1</smiles>

2A

$(1 S, 2 R, 4 R) \quad(1 R, 2 S, 4 S)$

2B
3<smiles>CC(C)[C]1CC[C@@H](O)[C@H](N)C1</smiles>

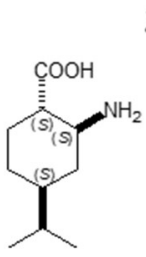

3A

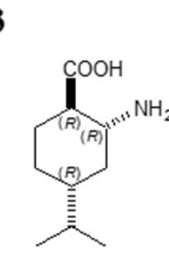

3B

$(1 S, 2 S, 4 S) \quad(1 R, 2 R, 4 R)$

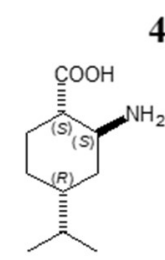

4A

$(1 S, 2 S, 4 R) \quad(1 R, 2 R, 4 S)$

12. ábra Limonén alapú karbociklusos $\beta$-aminosavak

5

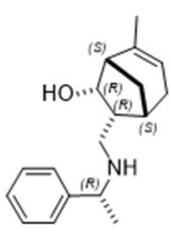

$5 A$

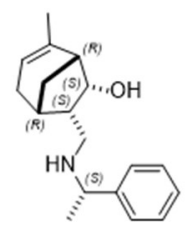

5B
6

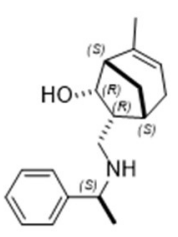

6A

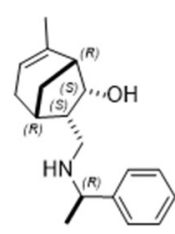

6B

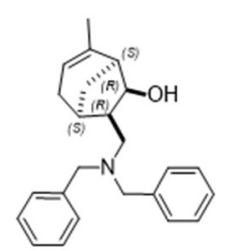

7A
7

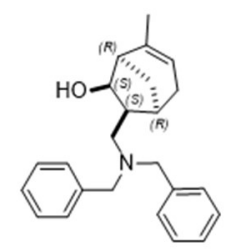

7B

$\left(1 S, 5 S, 6 R, 7 R, 1^{\prime} R\right) \quad\left(1 R, 5 R, 6 S, 7 S, 1^{\prime} S\right) \quad\left(1 S, 5 S, 6 R, 7 R, 1^{\prime} S\right)$

$\left(1 R, 5 R, 6 S, 7 S, 1^{\prime} R\right)$

$(1 S, 5 S, 6 R, 7 R)$

$(1 R, 5 R, 6 S, 7 S)$

9

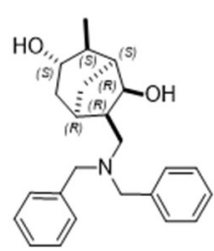

9A

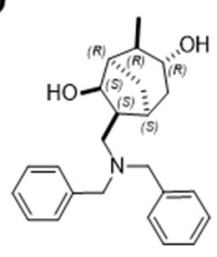

9B

8A

8B

$(1 R, 3 S, 4 S, 5 S, 6 R, 7 R) \quad(1 S, 3 R, 4 R, 5 R, 6 S, 7 S)$

13. ábra Limonénvázas 1,3-aminoalkoholok, illetve 1,3,5-, és 1,3,6-aminodiolok 
2. táblázat $N$-metilszubsztituált és amidált ciklusos $\beta$-aminosavak

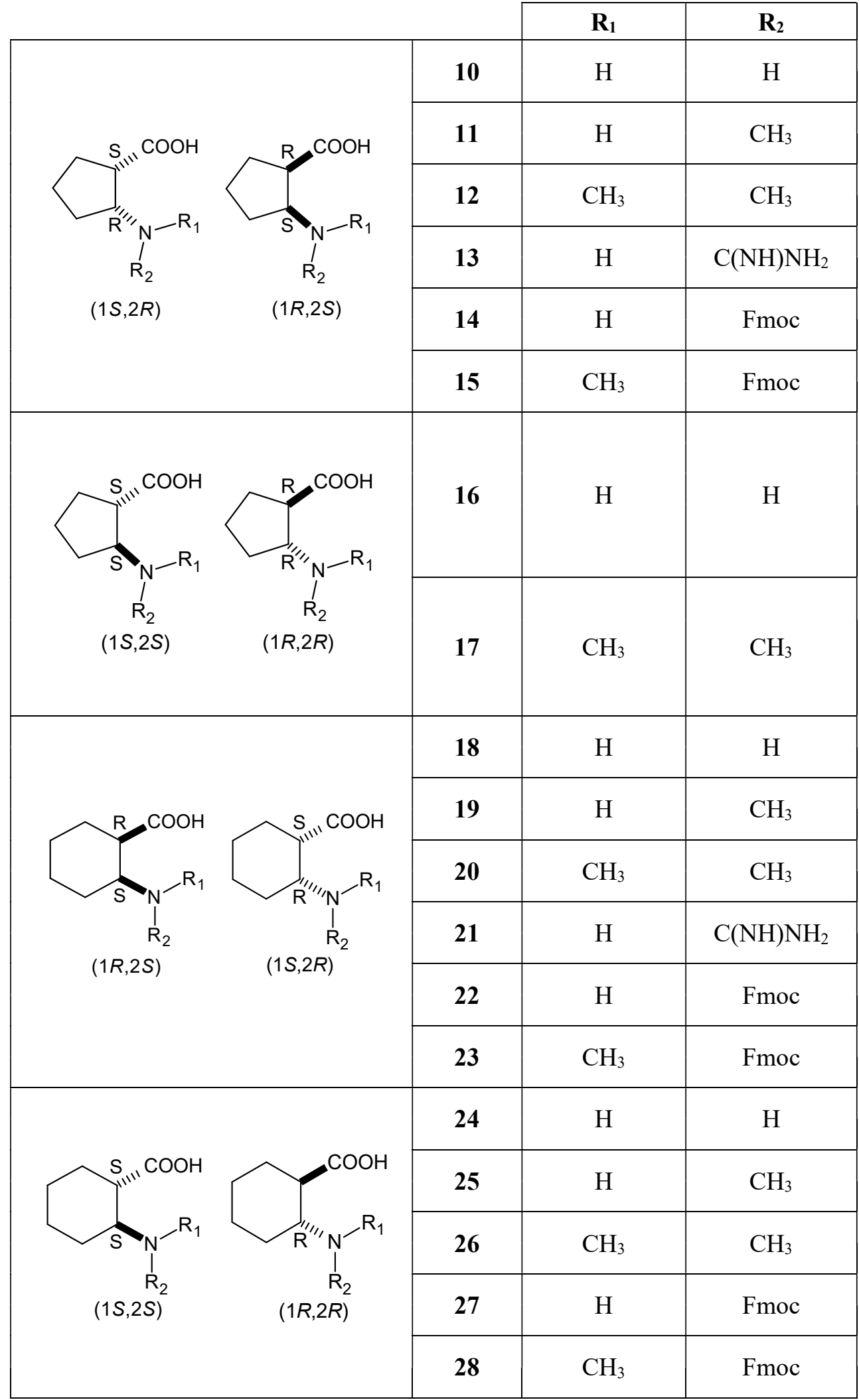




\subsection{Felhasznált vegyszerek}

A kísérletek során alkalmazott mozgófázisok elkészítéséhez használt HPLC tisztaságú $n$-hexán, metanol $(\mathrm{MeOH})$, acetonitril $(\mathrm{MeCN})$, etanol (EtOH), propán-1-ol (1PrOH), propán-2-ol (2-PrOH), butanol $(\mathrm{BuOH})$ és terc-butanol $(t-\mathrm{BuOH})$ oldószerek, valamint a különböző adalékok, úgymint trietil-amin (TEA), dietil-amin (DEA), hangyasav (FA) és ecetsav $(\mathrm{AcOH})$ VWR (Radnor, PA, USA) gyártmányúak voltak. A nagytisztaságú vizet egy TU UV/UF típusú (VWR) víztisztító berendezéssel állítottuk elő. A korona kisülési detektort (Corona CAD) 4.5 tisztaságú nitrogéngázzal (Linde, Magyarország) müködtettük. SFC méréseink során alkalmazott élelmiszeripari tisztaságú $\mathrm{CO}_{2}$-ot a Messer Hungarogáz Kft-től (Budapest, Magyarország) szereztük be.

\subsection{Alkalmazott készülékek}

Méréseimhez három különböző HPLC rendszert és egy SFC mérökészüléket alkalmaztam. Az alkalmazott HPLC rendszerek a következők voltak:

$\star$ I. rendszer: Waters Breeze 1525 bináris pumpa, Waters 2487 kétcsatornás UV-Vis detektor, 717 Plus automata adagoló, Waters oszloptermosztát.

$\star$ II. rendszer: Waters M-600 gradiens HPLC pumpa, Waters M-2996 fotodiódasoros detektor (Waters, MA, USA), Jasco 2031 Plus törésmutató mérésén alapuló detektor (Jasco Tokyo, Japan), Rheodyne $712520 \mu$ l térfogatú mintaadagoló (Cotati, CA, USA).

$\star$ A III. rendszer egy 1100 sorozatszámú Agilent Technologies (Waldbronn, Németország) HPLC készülék, melynek összetevői: oldószer gázmentesítő, pumpa, automata mintaadagoló, oszloptermosztát, ötcsatornás UV-Vis detektor, ESA Biosciences Inc. koronakisülési detektor (Corona CAD, Chelmsford, MA, USA).

Az alkalmazott SFC rendszer bináris pumpával, automata mintaadagolóval, ellennyomás szabályozóval, oszloptermosztáttal és fotodiódasoros detektorral felszerelt Waters Acquity Ultra Performance (UPC ${ }^{2}$, Milford, MA, USA) mérőberendezés volt.

$\mathrm{Az}$ adatok kiértékelését az I-II. HPLC rendszer, valamint a Waters $\mathrm{UPC}^{2}$ SFC mérőberendezés esetén Empower 2 adatfeldolgozó és kiértékelő szoftverrel végeztem el (Waters, Milford, MA, USA). A III. HPLC rendszer alkalmazásakor ChemStation szoftvert használtam (Agilent Technologies). 
A hőmérséklet elválasztásra gyakorolt hatásának tanulmányozása során a fentebb ismertetett HPLC és SFC rendszerek saját termosztátján kívül egy Alpha RA 8 folyadék termosztátot (Lauda, Németország) alkalmaztam. Ezen kívül egyéb méröberendezések közé tartozik egy Rotring Socin Cleaner ultrahangos fürdő (Rotring Gmbh, Hamburg, Németország), mellyel az oldószerek gázmentesítését oldottam meg. Az ultrahangos gázmentesítés mellett He átbuborékoltatást is alkalmaztam a mozgófázis gázmentesítésére. A pH méréseket egy Thermo Orion 420 pH mérő készülékkel (Orion, USA) végeztem el. A minták tömegének méréséhez Pioneer PA 214 C (Ohaus, USA) digitális mérleget használtam.

\subsection{Alkalmazott királis állófázisok}

^ Makrociklusos antibiotikum (glikopeptid) alapú oszlopok: Méréseimhez kereskedelmi forgalomban kapható Chirobiotic $^{T M}$ kolonnákat alkalmaztam, amelyek makrociklusos glikopeptid alapú királis szelektorokkal rendelkeznek. A Chirobiotic $^{T M} T$ teikoplanint, a Chirobiotic $^{T M} T A G$ teikoplanin aglikont, míg a Chirobiotic ${ }^{T M} R$ risztocetin A szelektort tartalmazott. Az oszlopok mérete 250 x 4,6 $\mathrm{mm}$ és $5 \mu \mathrm{m}$ szemcsemérettel rendelkeznek (Astec, Whippany, NJ, USA). A holtidő meghatározásához metanolban oldott acetont, valamint 1,3,5-tri-t-butilbenzol oldatát alkalmaztam.

• Ioncserélő típusú oszlopok: Chiralpak ${ }^{\circledR} Z W I X(+)$ és $Z W I X(-)$ ikerionos állófázisokat (150 x 3 mm, $3 \mu \mathrm{m}$ szemcseméret) használtam, melyek forgalmazója a Chiral Technologies Europe (Illkirch, Franciaország). A holtidő meghatározását metanolban oldott aceton adagolásával végeztem el.

^ Módosított poliszacharid típusú oszlopok: A kísérletek során módosított cellulóz és amilóz alapú állófázisokat használtam. A Lux Cellulose-2 oszlop szelektora cellulóz-trisz(3-klór-4-metilfenilkarbamát), a Lux Cellulose-3 oszlopé cellulóz-trisz-(4-metilbenzoát), a Lux Cellulose-4 oszlopé cellulóz trisz-(4-klór-3-metilfenilkarbamát), Lux i-Cellulose-5 oszlopé cellulóz trisz-(3,5-diklórfenilkarbamát), a Lux Amylose-1 oszlopé amilóz trisz-(3,5dimetilfenilkarbamát), míg a Lux Amylose-2 oszlopé amilóz trisz-(5-klór-2metilfenilkarbamát).. Ezen oszlopok fizikai paramétere 250 x 4,6 mm, szemcseméretük pedig $5 \mu \mathrm{m}$. A cellulóz trisz-(3,5-dimetilfenilkarbamát) szelektorral rendelkező Lux Cellulose-1 oszlopot 250 x 4,6 mm méret és $3 \mu \mathrm{m}$ szemcseméret jellemzi. Az összes alkalmazott poliszacharid típusú oszlop gyártója a Phenomenex (Torrance, CA, USA). A holtidő meghatározását eluensben oldott 1,3,5-tri-t-butilbenzol oldatával végeztem el. 


\section{Eredmények és értékelésük}

Az irodalmi összefoglalóban részletesen tárgyalt három állófázis-család sorrendjét követve eredményeimet három külön fejezetben mutatom be. Az egyszerübb áttekinthetőség érdekében az értekezés elején feltüntetett rövidítéseket, valamint a vizsgált molekulák kísérleti részben bevezetett számozási rendszerét használom.

\subsection{Limonén alapú karbociklusos $\beta$-aminosavak elválasztása makrociklusos glikopeptid alapú állófázisokon}

\subsubsection{A mozgófázis összetevőinek hatása az elválasztásra}

\subsubsection{A mozgófázis pH-jának hatása a kromatográfiás viselkedésre}

A mozgófázis pH-jának kromatográfiás viselkedésre gyakorolt hatása tanulmányozásával értékes információkhoz juthatunk az enantioszelektív elválasztás mechanizmusát illetően. Az irodalmi áttekintésben részletesen bemutattam, hogy a makrociklusos glikopeptid alapú állófázisok maguk is rendelkeznek ionos vagy ionizálható funkciós csoportokkal. A teikoplanin aglikon ionos tulajdonsága egy primer amino- $\left(p K_{a} \sim\right.$ 9,2), valamint egy karboxilcsoport $\left(p K_{a} \sim 2,5\right)$ meglétének köszönhető [30]. Az elválasztandó modellvegyületek hasonló $p K_{a}$ értékekkel rendelkeznek (MarvinSketch szoftver segítségével meghatározva, $p K_{a} \sim 9,2$ és 2,3), ennélfogva a vizsgált $\mathrm{pH}$ tartományban $(\mathrm{pH}=3-6)$ mind a szelektor, mind pedig az elválasztani kívánt aminosavak ikerionos szerkezetet vehetnek fel.

Kísérleteim során a nagy víztartalmú eluensben szerves módosító hozzáadása után pH mérő alkalmazásával állítottam be a pH-t. Az így kialakuló ,aktuális” $\mathrm{pH}\left(\mathrm{pH}_{\mathrm{a}}\right)$ elválasztásra gyakorolt hatását Chirobiotic ${ }^{T M} T A G$ oszlopon tanulmányoztam az 1 és 4 vegyületek esetén $0,1 \%$ TEAA $(\mathrm{pH}=3-6) / \mathrm{MeOH}(90 / 10 v / v)$ eluensösszetételt alkalmazva. A 14. ábra adatait megfigyelve elmondható, hogy mindkét vegyület esetén a mozgófázis pH-jának csökkentésével jelentősen nőtt a korábban eluálódott enantiomer retenciója $\left(k_{l}\right)$. A pH csökkenését kísérő növekvő visszatartás a vizsgált vegyületek protonált amincsoportja, valamint az alkalmazott szelektor karboxilcsoportja között kialakuló elektrosztatikus kölcsönhatások retencióban betöltött meghatározó szerepét jelzi. Az alkalmazott pH tartományban $(\mathrm{pH}=3-6)$ a szelektivitás $(\alpha) \mathrm{pH}_{\mathrm{a}}=5$ értéken ért el maximumot, részleges elválasztást elérve. A szerves módosítót tartalmazó rendszer pH-jának csökkenése tehát az 
ionos kölcsönhatások erősítése révén növekvő retenciós időket eredményezett, viszont a kialakuló kölcsönhatások nagy része nemszelektív, ezáltal az enantiomerek megkülönböztetésének hatékonysága kedvezőtlen irányba változott, amint azt a felbontás $\left(R_{S}\right)$ értékei is mutatják. Eredményeim jól tükrözik, hogy a mozgófázis $\mathrm{pH}$-jának változtatása mind a szelektor, mind az elválasztandó vegyületek ionizáltságát képes befolyásolni, ezáltal a retenciós viselkedésre és az enantioszelektivitás kialakulására is jelentős hatással lehet.
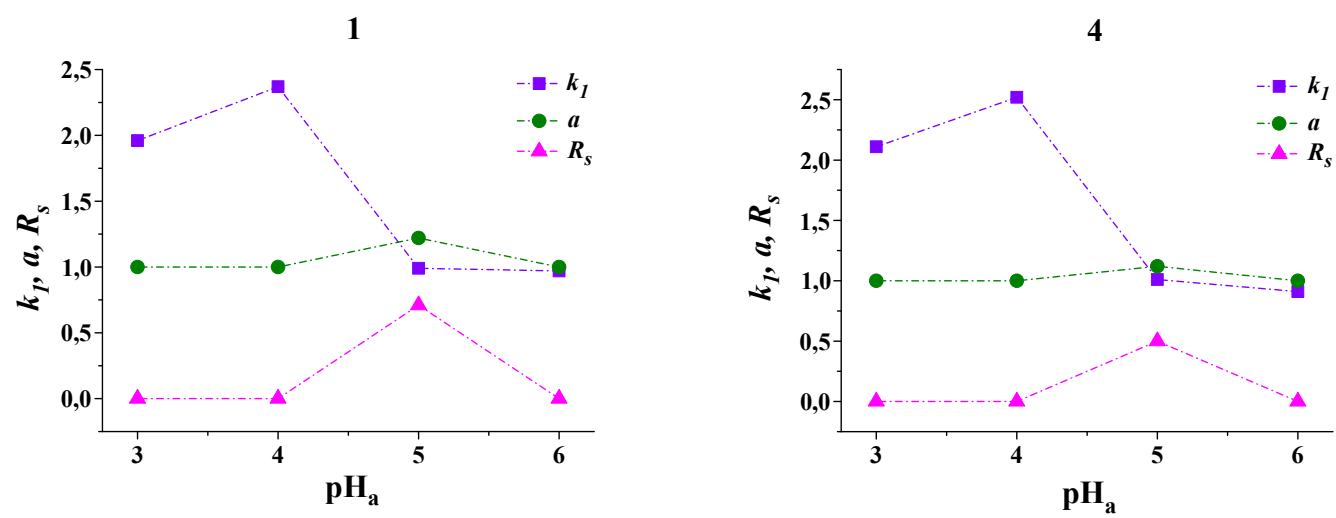

14. ábra A mozgófázis $\mathrm{pH}$-jának hatása a kromatográfiás paraméterekre Chirobiotic $^{T M}$ $T A G$ oszlopon

Kromatográfiás körülmények: oszlop, Chirobiotic ${ }^{T M} T A G$; mozgófázis, $0,1 \%$ TEAA $\left(\mathrm{pH}_{\mathrm{a}}=3-6\right) / \mathrm{MeOH}(90 / 10$

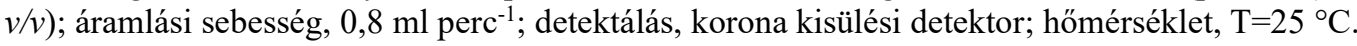

\subsubsection{Eluensösszetétel-változás hatása az elválasztásra}

A makrociklusos glikopeptid alapú szelektorokat legelterjedtebben RP és PI módban használják enantioszelektív elválasztásokra. Ilyen kromatográfiás körülmények között mozgófázisként jellemzően $\mathrm{MeOH}$, vagy $\mathrm{MeOH}$ és víz elegye, mint poláris oldószer használatos. Az eluenshez ionos adalékként bázist (pl. TEA), savat (pl. AcOH), valamint megfelelő sót (pl. trietil-ammóniumacetát, TEAA) alkalmaznak. A mozgófázis változó összetételének elválasztásra gyakorolt hatását az 1 és 4 vegyületek esetén vizsgáltam teikoplanin, teikoplanin aglikon, valamint risztocetin A szelektorokkal rendelkező makrociklusos glikopeptid alapú oszlopokon (Chirobiotic ${ }^{T M} T$, TAG és $R$ ). A kísérleteim során megfigyelt kromatográfiás adatok alakulását a 15. ábra szemlélteti.

Az eluenst alkotó $0,1 \%$ TEAA $\left(\mathrm{pH}_{\mathrm{a}}=5,00\right)$ és $\mathrm{MeOH} 90 / 10-10 / 90(v / v)$ arány változtatásakor a legtöbb esetben $k_{1}$ értékei minimumgörbe mentén változtak. Ez alól kivételnek számított a $\mathbf{4}$ vegyület retenciós viselkedése Chirobiotic ${ }^{T M} T A G$ oszlopon, ahol az eluens víz tartalmának növelésével, azaz a $\mathrm{MeOH}$ tartalom csökkenésével párhuzamosan csökkent a visszatartás. A legtöbb esetben a vízben gazdag eluens alkalmazása (RP mód) során $k_{1}$ növekedését figyeltem meg, melynek magyarázata a szelektor „kosarában” 
kialakuló hidrofób-hidrofób kölcsönhatásokban keresendő. RP körülmények között a poláris oldószer molekulái nem töltik ki a makrociklusok által körülölelt hidrofób „üregeket”, ezáltal az elválasztandó komponensek és a szelektor között hidrofób kölcsönhatások kialakítására nyílik lehetőség. Amikor az eluens $\mathrm{MeOH}$ tartalma meghaladta a 40-60 v\%-ot, $k_{1}$ értékei növekedtek. Ezt a jelenséget újabban HILIC módnak (hydrophilic interaction liquid chromatography) hívjuk. Nagy szerves oldószer tartalmú eluensben (víz/MeOH, víz/MeCN, víz/THF) a mozgófázis polaritása lecsökken, a poláris elválasztandó komponensek szolvatációja (oldhatósága) kisebb, ennélfogva a molekulák szívesebben tartózkodnak az állófázison, mint a mozgófázisban. Ilyen kromatográfiás körülmények között az ionos és dipólusos kölcsönhatások is feleerősödhetnek, míg a hidrofób kölcsönhatások visszaszorulnak. Eredményeim alapján tehát elmondható, hogy a retenciós görbék alakja, minimumának helye, valamint a minimumpont elötti és utáni növekedés meredeksége eltérő mértékben változott a vizsgált komponensek szerkezetétől és az alkalmazott állófázistól függően, ahogy azt korábban már megfigyelték Armstrong és munkatársai különböző aminosavak elválasztásakor [19].

A szelektivitás $(\alpha)$ és a felbontás $\left(R_{S}\right)$ értékeiben a MeOH tartalom változtatása során általános tendencia nem volt megfigyelhető. A 4 vegyület esetén az eluens növekedő $\mathrm{MeOH}$ tartalmával a felbontás értékei jelentős mértékben növekedtek, míg a szelektivitás csekély mértékben változott Chirobiotic ${ }^{T M} T$ és $T A G$ oszlopokon. Az 1 komponens esetén ettől eltérő kromatográfiás viselkedést tapasztaltam: Chirobiotic $^{T M} T$ oszlopon a $\mathrm{MeOH}$ nagyobb térfogatarányban való alkalmazása kisebb enantioszelektivitáshoz, s egyben kevésbé hatékony elválasztáshoz vezetett, míg Chirobiotic ${ }^{T M} T A G$ oszlopon $\alpha$ és $R_{S}$ értékei a korábban említett retenciós viselkedéshez hasonlóan minimumgörbe mentén változtak. Chirobiotic ${ }^{T M} R$ kolonnán $k_{1}$ értékei szintén minimum jellegü görbét írtak le, viszont egyik alkalmazott eluensösszetétel sem biztosította a tanulmányozott modellvegyületek eredményes elválasztását (kivéve az 1 anyag 0,1\% TEAA(pH=5,00)/MeOH 90/10 v/v összetételü mozgófázis alkalmazásakor). 


\section{Chirobiotic $^{T M}$ T}
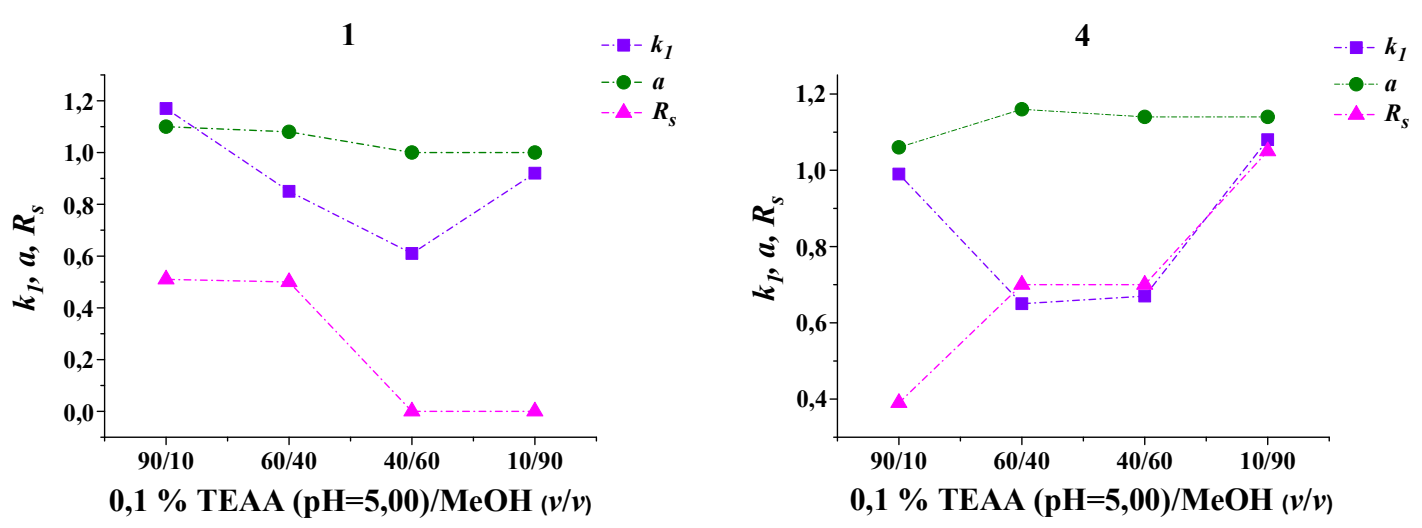

\section{Chirobiotic $^{T M}$ TAG}
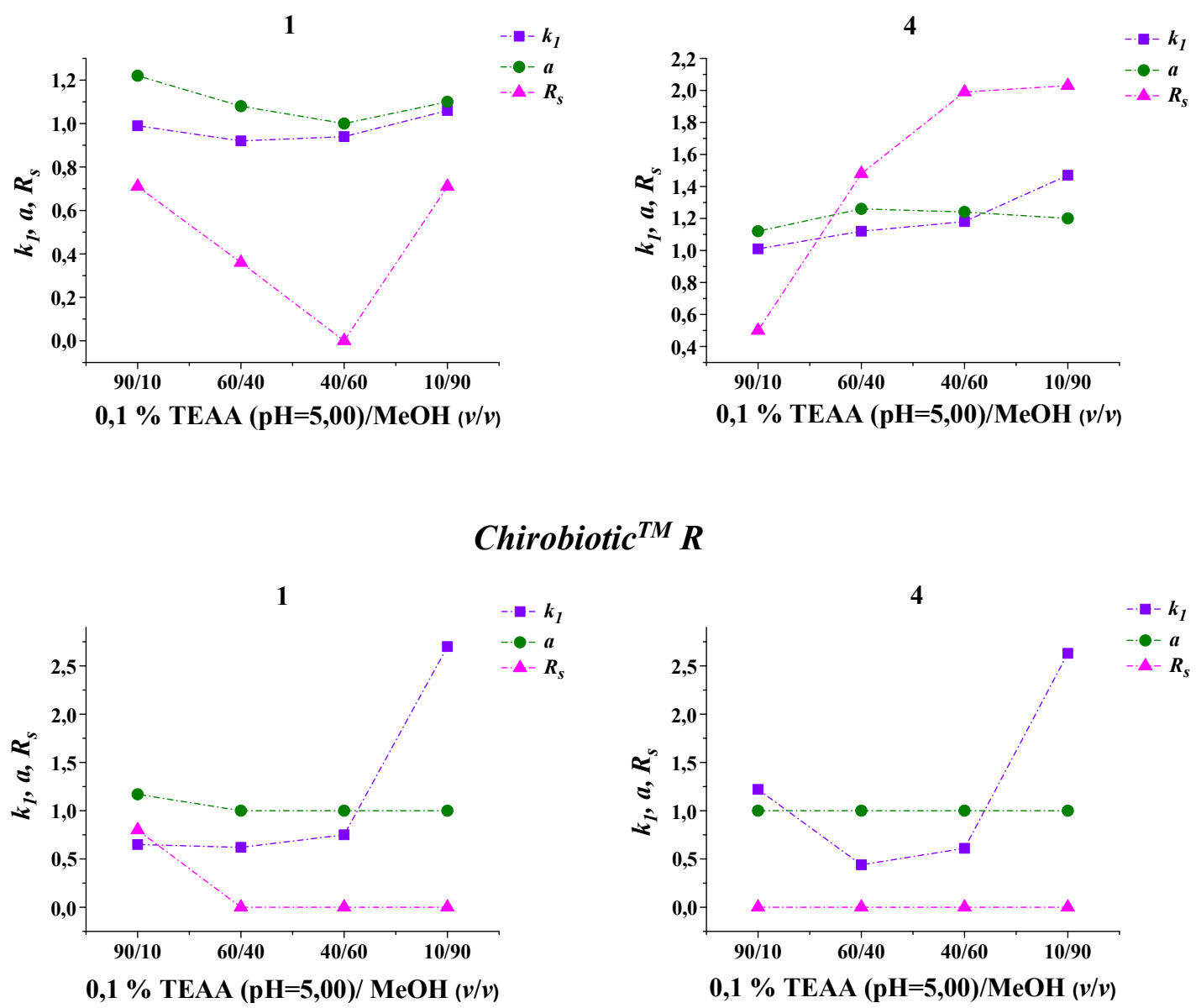

15. ábra A mozgófázist alkotó oldószerek összetételének hatása a kromatográfiás paraméterekre Chirobiotic ${ }^{T M} T, T A G$ és $R$ oszlopokon

Kromatográfiás körülmények: oszlopok, Chirobiotic ${ }^{T M} T$, TAG és $R$; mozgófázis, $0,1 \%$ TEAA $\left(\mathrm{pH}_{\mathrm{a}}=5,00\right) / \mathrm{MeOH}(90 / 10,60 / 40,40 / 60$ és $10 / 90 \mathrm{v} / \mathrm{v})$; áramlási sebesség, $0,8 \mathrm{ml}$ perc $^{-1}$; detektálás, korona kisülési detektor; hömérséklet, $\mathrm{T}=25^{\circ} \mathrm{C}$. 


\subsubsection{A mozgófázist alkotó alkohol anyagi minőségének hatása}

Az alkohol, mint mozgófázis-alkotó anyagi minőségének hatását Chirobiotic ${ }^{T M} T A G$ oszlopon vizsgáltam az 1 és 4 vegyületek esetén $0,1 \%$ TEAA $\left(\mathrm{pH}_{\mathrm{a}}=5,00\right) /$ alkohol $(90 / 10 v / v)$ oldószereleggyel (16. ábra). Eluens módosítóként MeOH-t, EtOH-t, 1-PrOH-t és 2-PrOH-t alkalmaztam állandó moláris koncentrációban (0,25 M), amely MeOH: 10, EtOH: 14,5, 1PrOH: 18,5 és 2-PrOH: 19,1 v\%-ot jelent.

A megfigyelt kromatográfiás adatok rámutattak, hogy a mozgófázisban a különböző anyagi minőségü alkoholokat állandó moláris koncentrációban alkalmazva $k_{1}$ értékei rendkívül kis mértékben változtak az alkohol anyagi minőségének változtatásával. Mindkét vegyület esetén a legnagyobb retenciós időket $\mathrm{MeOH}$, a legkisebb visszatartást pedig 1PrOH alkalmazásakor tapasztaltam. A szelektivitás az 1 vegyület elválasztásakor meglehetősen szük értéktartományban $(\alpha=1,13-1,19)$ változott, míg a 4 komponens esetében nagyobb változást ( $\alpha=1,05-1,50)$ figyeltem meg. A legnagyobb enantioszelektivitás 1-PrOH alkalmazásakor volt jellemző, míg a legnagyobb felbontást 1-PrOH, illetve $\mathrm{MeOH}$ alkalmazása kínálta a vizsgált limonénvázas karbociklusos $\beta$-aminosavak elválasztása során.
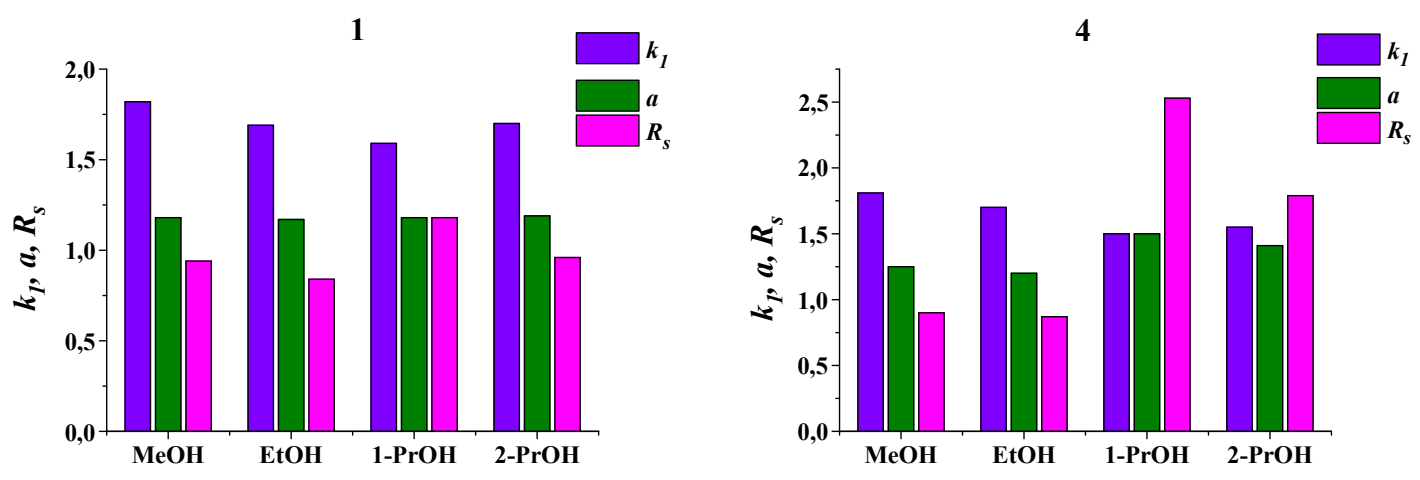

16. ábra Az alkohol anyagi minőségének hatása a kromatográfiás paraméterekre Chirobiotic $^{T M} T A G$ állófázison

Kromatográfiás körülmények: oszlop, Chirobiotic ${ }^{T M} T A G$; mozgófázis, $0,1 \%$ TEAA $\left(\mathrm{pH}_{\mathrm{a}}=5,00\right) /$ alkohol $(90 / 10 \mathrm{v} / \mathrm{v})$; áramlási sebesség, $0,8 \mathrm{ml} \mathrm{perc}^{-1}$; detektálás, korona kisülési detektor; hőmérséklet, $\mathrm{T}=25^{\circ} \mathrm{C}$.

Az eddigi eredmények alapján látható, hogy az alkohol anyagi minősége bár hatással van az enantioszelektív elválasztásokra, mindazonáltal a tapasztalt retenciós viselkedés valószínüleg nem áll közvetlen összefüggésben az alkoholok polaritásával. Amikor az alkoholok, mint eluens-összetevők a mozgófázisban állandó moláris koncentrációban vannak jelen, a hidrofób kölcsönhatásokat kevésbé befolyásolja az alkohol anyagi minőségének változtatása. Az alkalmazott állófázis enantiomer-felismerőképességének kialakításáért sokkal inkább a különböző mértékü szolvatációs hatások lehetnek felelősek. 
Természetesen a mozgófázis-alkotók elválasztásra gyakorolt hatása nagymértékben függ az elválasztandó komponensek szerkezetétől, melyre az 5.1.2. fejezetben részletesebben ki fogok térni.

\subsubsection{Ellen- és kísérő ionok koncentrációjának hatása}

A makrociklusos antibiotikum alapú állófázisok multimodálisak, azaz RP, NP, PI és PO módban egyaránt használhatók. Az eddig ismertetett eredmények alapján látható, hogy RP körülmények között a vízben gazdagabb eluens használatával a hidrofób-hidrofób kölcsönhatások kerülnek elötérbe. PI módban a mozgófázist alkotó vizet protikus, ám kevésbé poláris $\mathrm{MeOH}-\mathrm{ra}$ váltva (az előbb említett hidrofób-hidrofób kölcsönhatásokat háttérbe szorítva) a poláris aminosavak szolvatációja gyengül (HILIC hatás), ezáltal az ionos kölcsönhatások előtérbe kerülhetnek. A megfelelő ionizáltság érdekében az eluensként alkalmazott oldószerelegyhez sav és bázis módosítókat kell adagolni. Amennyiben a mozgófázis enyhén savas, úgy mind a szelektor, mind az aminosav ikerionos szerkezetet vehet fel. Ennek következtében nagyobb hatótávolságú elektrosztatikus kölcsönhatások alakulhatnak ki a szelektor és a vizsgált komponensek anionos- és kationos részei között, segítve ezáltal a királis felismerést. Ebben az esetben a mozgófázisban jelen levő ionok versengeni fognak az elválasztandó komponensekkel a kölcsönható helyekért, melynek eredményeképp a nagyobb ionkoncentráció kisebb retenciót eredményez. Az úgynevezett sztöchiometrikus helyettesítési modell [120, 121] szerint, amennyiben a retenciós mechanizmust ionos kölcsönhatások határozzák meg, megfelelő jósággal $\left(\mathrm{R}^{2}>0,98\right)$ leírható lineáris kapcsolat áll fenn az elsőként eluálódó enantiomer retenciós tényezőjének tízes alapú logaritmusa $\left(\lg k_{l}\right)$ és az ellenion koncentrációjának tízes alapú logaritmusa $(\lg$ cellenion) között, ahol az egyenes meredeksége arányos az ioncsere folyamata során fellépő effektív töltéssel.

Munkám során azt a kérdést kívántam tisztázni, hogy a fentebb ismertetett sztöchiometrikus helyettesítési modell makrociklusos glikopeptid alapú állófázisok esetén is megfelelő jósággal írja-e le az elválasztások során megfigyelt kromatográfiás viselkedést, ami bizonyítékul szolgálhat az ionos kölcsönhatási folyamatok jelenlétéhez. Ennek vizsgálata érdekében kísérleteimet Chirobiotic $^{T M} T A G$ oszlopon hajtottam végre olyan eluensekkel, amelyek MeOH-t, illetve TEA-t és AcOH-t tartalmaztak 1:1 arányban, de az alábbi különböző koncentrációkban: 1,75/1,75, 4,375/4,375, 8,75/8,75, 17,5/17,5 és 
35,0/35,0 (mM/mM). Az 1A, 2B, 3A és 4A enantiomerek kromatográfiás jellemzőinek alakulását a 17. ábrán szemléltetem.

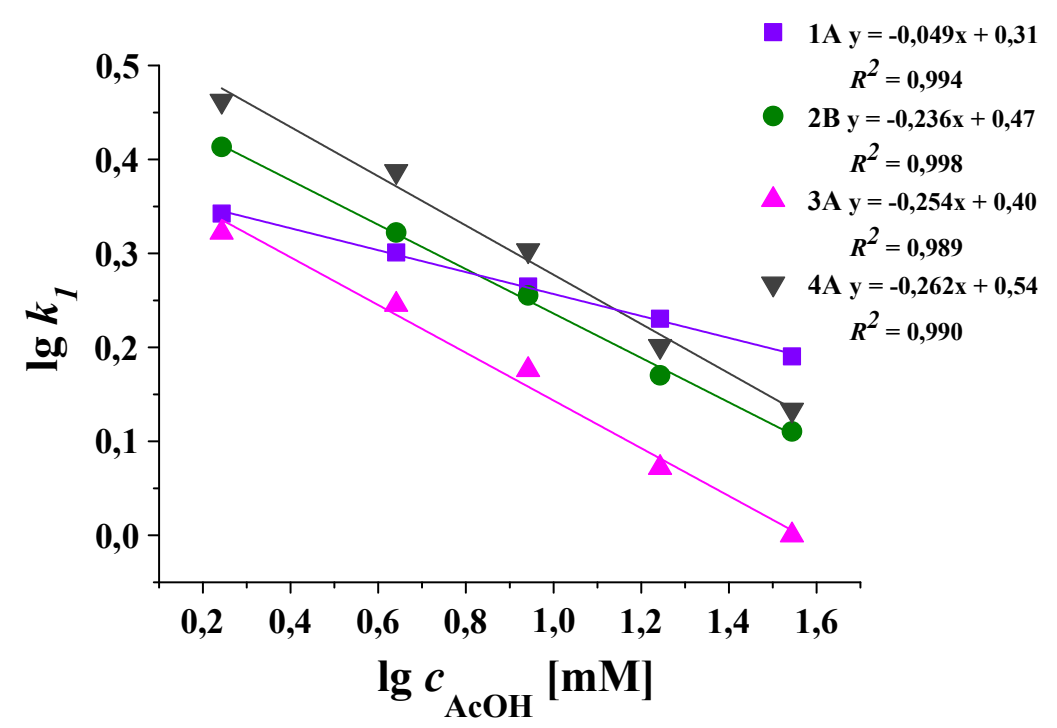

17. ábra Az ellenion koncentrációjának hatása az elsőként eluálódó enantiomer retenciós tényezőjére $\left(k_{1}\right)$ Chirobiotic ${ }^{T M} T A G$ oszlopon

Kromatográfiás körülmények: oszlop, Chirobiotic ${ }^{T M} T A G$; mozgófázis, MeOH és AcOH/TEA $(1,75 / 1,75$, 4,375/4,375, 8,75/8,75, 17,5/17,5 és 35,0/35,0 (mM/mM)); áramlási sebesség, $0,8 \mathrm{ml} \mathrm{perc}^{-1}$; detektálás, korona kisülési detektor; hömérséklet, $\mathrm{T}=25^{\circ} \mathrm{C}$.

Amint azt említettem, a sztöchiometrikus helyettesítési modell alkalmazásakor a lg $k_{1}-\lg c_{\text {ellenion }}$ egyenes meredekségének alakulása függ az elválasztandó komponens és az ellenion effektív töltéseinek arányától. Azon vegyületek esetén, melyekkel az alkalmazott szelektor kationcsere folyamatán keresztül képes kölcsönhatás kialakítására, a $\lg k_{1}-\lg$

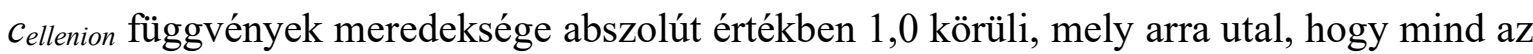
ellenion, mind az elválasztandó komponens protonálódott és hasonló töltésekkel rendelkeznek [54, 122]. Limonén alapú karbociklusos $\beta$-aminosavak elválasztása során a lg $k_{1}-\lg c_{\text {ellenion }}$ egyenesek meredeksége ennél sokkal kisebbnek adódott: abszolút értékben 0,05 az 1A, míg 0,25 körül a 2B, 3A és 4A enantiomerek esetén (17. ábra). Ez a jellegzetes különbség ráirányítja a figyelmet az ikerionos, valamint a monoionos állófázisok eltérő elválasztási mechanizmusára. Kutatócsoportunk [123, 124], valamint Hoffmann és munkatársainak [58] korábbi eredményei azt mutatták, hogy az ionpár kölcsönhatás kialakítására képes komponensek ikerionos állófázisokon történő elválasztásakor a $\lg k_{l}-\lg$ $c_{\text {ellenion }}$ függvények meredekségei $0,1-0,3$ között alakultak. Karbociklusos $\beta$-aminosavak elválasztása esetén a vizsgált teikoplanin aglikon szelektor tehát az ikerionos állófázisokhoz közelebb álló viselkedést mutatott. Az alkalmazott kromatográfiás körülmények között (a 
mozgófázisban a sav és bázis módosítók 1:1 arányban vannak jelen) a szelektor és az aminosav is ikerionos szerkezettel bír, ennélfogva az ellentétes töltésü funkciós csoportok között kialakuló ionos kölcsönhatások jelentős mértékben járulnak hozzá a retenció alakulásához. Eredményeimmel sikerült elsőként alátámasztani, hogy az ioncsere folyamata makrociklusos glikopeptid alapú állófázisok esetén is fontos szerepet tölthet be a királis felismerés folyamatában, valamint a sztöchiometrikus helyettesítési modell ezen állófázisok esetén is megfelelő jósággal alkalmazható a retenciós mechanizmus értelmezésére. Mivel a makrociklusos antibiotikumok komplex szerkezetükből adódóan számos kölcsönható hellyel rendelkeznek, természetesen nem csak ionos, hanem további szelektív kölcsönhatások is elősegíthetik a királis felismerést.

\subsubsection{A szénhidrátegységek hatása a királis felismerésre}

A makrociklusos antibiotikum alapú állófázisok közül a teikoplanin, valamint a teikoplanin aglikon a legszélesebb körben alkalmazott szelektorok. A 3.2.1.1. fejezetben részletesen kifejtettem, hogy e két szelektor a cukoregységek meglétében különbözik egymástól. A szénhidrátegységek jelenléte (vagy épp hiánya) különböző módon képes befolyásolni a királis megkülönböztetést. Egyrészt, a cukoregységek kitölthetik a szelektor „kosarában” fellelhető helyeket, másrészt sztérikusan gátolhatják az állófázis lehetséges kölcsönható helyeihez történő hozzáférhetőséget. Arról sem szabad megfeledkezni, hogy a szelektor ezen részei maguk is királisak, s hidroxil, éter, valamint amid funkciós csoportok megléte révén maguk is további kölcsönható helyekként müködhetnek a királis felismerés folyamatában [29]. A cukoregységek elválasztásban betöltött szerepének tanulmányozása tehát azért fontos, mert az elválasztani kívánt vegyület és a szelektor között létrejövő kölcsönhatások alakulása nagymértékben függ attól, hogy az enantiomer hogyan képes illeszkedni az aglikonhoz. A szénhidrátegységek hatása termodinamikai oldalról megközelítve a $\Delta\left(\Delta G^{\circ}\right)=-R T \ln \alpha$ egyenlet alapján kiszámolt $\Delta\left(\Delta G^{\circ}\right)_{T A G}-\Delta\left(\Delta G^{\circ}\right)_{T}$ különbséggel jellemezhető, ahol $\Delta\left(\Delta G^{\circ}\right)_{T A G}$ a teikoplanin aglikon, míg $\Delta\left(\Delta G^{\circ}\right)_{T}$ a teikoplanin szelektoron az adott enantiomerpárra jellemző, álló- és mozgófázis közötti megoszlásuk során fellépő szabadentalpia-változás különbségét jelenti egy adott hőmérsékleten. A 18. ábrán a négy vizsgált enantiomerpárra kiszámolt $\Delta\left(\Delta G^{\circ}\right)_{T A G}-\Delta\left(\Delta G^{\circ}\right)_{T}$ értékeket mutatom be RP és PI körülmények között. A negatív $\Delta\left(\Delta G^{\circ}\right)_{T A G}-\Delta\left(\Delta G^{\circ}\right)_{T}$ értékek azt jelzik, hogy az adott sztereoizomerek elválasztása kedvezőbb volt a szénhidrátegységek nélküli szerkezettel rendelkező teikoplanin aglikon alapú állófázison. Ha a számított különbség pozitív értéknek 
adódik, az a teikoplanin szelektor alkalmazásával való eredményesebb elválasztásra utal (18. ábra). Eredményeim alapján megállapítható, hogy a vizsgált vegyületek elválasztása az esetek döntő többségében a teikoplanin aglikon alapú oszlopon bizonyult hatékonyabbnak. Egy adott mozgófázis összetételnél, $k_{1}$ értékei általában kisebbnek adódtak a teikoplanin szelektorral végzett elválasztások során, mint az aglikon alapú királis állófázis alkalmazásakor (15. ábra).

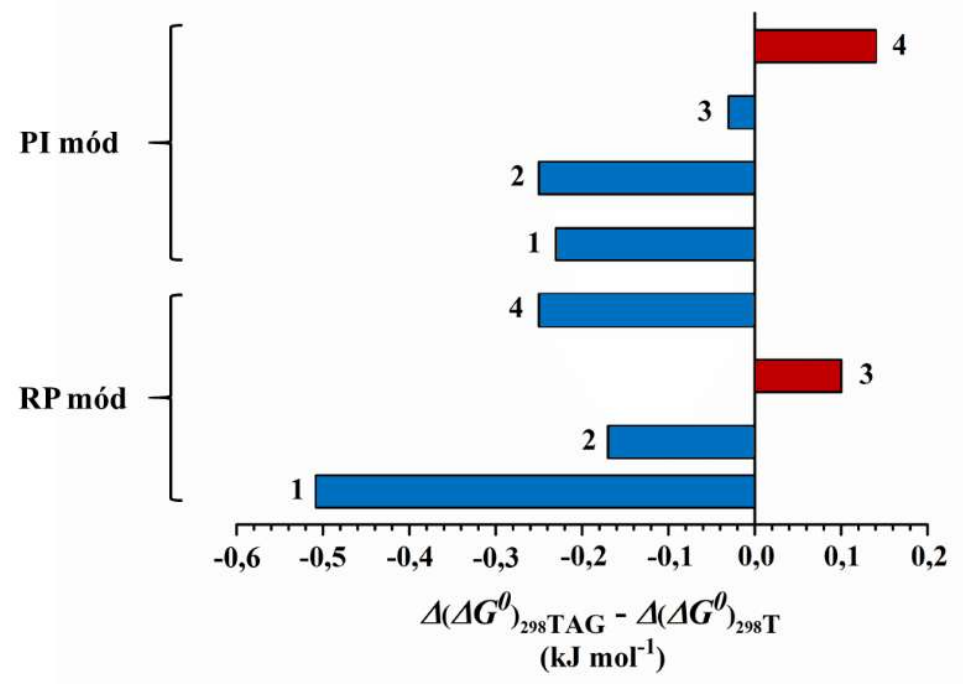

18. ábra A cukoregységek hatása limonénvázas karbociklusos $\beta$-aminosavak elválasztására Chirobiotic $^{T M}$ TAG és $T$ oszlopokon

Kromatográfiás körülmények: oszlopok, Chirobiotic ${ }^{T M} T e ́ s ~ T A G$, mozgófázis, MeOH/AcOH/TEA (100/0,1/0,1 $v / v / v), 0,1 \%$ TEAA $(\mathrm{pH}=5,00) / \mathrm{MeOH}\left(90 / 10\right.$ és 10/90 v/v); áramlási sebesség, 0,8 ml perc ${ }^{-1}$; detektálás, korona kisülési detektor; hőmérséklet, $\mathrm{T}=25^{\circ} \mathrm{C}$.

Összehasonlítva tehát a két oszlopot, Chirobiotic ${ }^{T M} T A G$ állófázison végzett elválasztásoknál nagyobb retenciót figyeltem meg, mint Chirobiotic ${ }^{T M} T$ oszlop esetében. Korábban hasonló következtetésekre jutottak Berthod [29], valamint D'Acquarica [125] és munkatársai különféle aminosavak kromatográfiás vizsgálata során, de hasonló tendenciákat fedeztek fel Péter és munkatársai is nem természetes $\alpha$-aminosavak, fenilalanin és tirozin analógok, illetve különféle cikloalkán- és cikloalkén vázzal rendelkező $\beta$-aminosavak elválasztásakor [33, 126]. A 3 vegyület RP körülmények között, míg a 4 komponens PI módban történő elválasztása során ellentétes viselkedést figyeltem meg. Ezen vegyületek királis megkülönböztetésének a teikoplanin szelektor kedvezett. Összefoglalva tehát, a meghatározott $\Delta\left(\Delta G^{\circ}\right)_{T A G}-\Delta\left(\Delta G^{\circ}\right)_{T}$ értékek rámutattak arra, hogy a szénhidrát részek az enantioszelektív elválasztásokra igen összetett hatással bírnak. A legtöbb limonénvázas karbociklusos $\beta$-aminosav esetén a Chirobiotic ${ }^{T M} T$ oszlop szelektorának cukoregységei sztérikus gátláson keresztül csökkentették az elválasztás hatékonyságát. Ez szintén rávilágít 
a makrociklusok által kialakított hidrofób ,üregek” királis felismerésben betöltött jelentős szerepére. A teikoplanin aglikon alapú Chirobiotic ${ }^{T M} T A G$ állófázis alkalmazásakor szénhidrátegységek hiányában - az említett sztérikus gátló hatás nem érvényesült. A szelektor egy fenolos és két alkoholos hidroxilcsoporttal is rendelkezik, melyek szabaddá válásával a kialakuló kölcsönhatások száma növelhető, minősége változtatható.

\subsubsection{A hőmérséklet hatása és termodinamikai paraméterek}

A hőmérséklet meglehetősen komplex módon képes befolyásolni a királis felismerést. Annak érdekében, hogy a hőmérséklet retenciós viselkedésre és enantioszelektivitásra gyakorolt hatását tanulmányozzam, egy kísérletsorozatot hajtottam végre mind a négy modellvegyület esetén, $5-40{ }^{\circ} \mathrm{C}$ hőmérséklettartományban Chirobiotic ${ }^{T M}$ $T A G$ oszlopot alkalmazva. Eredményeimet a megfelelő eluensösszetételekkel együtt a 3. táblázatban adtam meg.

3. táblázat Különböző hőmérsékleten mért kromatográfiás paraméterek $\left(k_{1}, \alpha, R_{S}\right)$ értékei Chirobiotic $^{T M} T A G$ oszlopon

\begin{tabular}{|c|c|c|c|c|c|c|c|c|}
\hline \multirow{2}{*}{ Vegyület } & \multirow{2}{*}{ Mozgófázis } & \multirow{2}{*}{$\begin{array}{c}k_{1}, \\
\alpha, \\
R_{S}\end{array}$} & \multicolumn{5}{|c|}{ Hőmérséklet $\left({ }^{\circ} \mathrm{C}\right)$} & \multirow{2}{*}{$\begin{array}{l}\text { Elúciós } \\
\text { sorrend }\end{array}$} \\
\hline & & & 5 & 10 & 20 & 30 & 40 & \\
\hline \multirow{3}{*}{1} & \multirow{3}{*}{ b } & $k_{1}$ & 1,73 & 1,72 & 1,66 & 1,54 & 1,43 & \multirow{3}{*}{$A<B$} \\
\hline & & $\alpha$ & 1,24 & 1,21 & 1,18 & 1,14 & 1,10 & \\
\hline & & $R_{S}$ & 1,14 & 1,07 & 1,17 & 1,05 & 0,86 & \\
\hline \multirow{6}{*}{2} & \multirow{3}{*}{$\mathbf{a}$} & $k_{1}$ & 1,69 & 1,61 & 1,46 & 1,35 & 1,26 & \multirow{3}{*}{$B<A$} \\
\hline & & $\alpha$ & 1,04 & 1,06 & 1,10 & 1,12 & 1,14 & \\
\hline & & $R_{S}$ & 0,20 & 0,20 & 0,35 & 0,77 & 1,14 & \\
\hline & \multirow{3}{*}{ b } & $k_{1}$ & 2,56 & 2,49 & 2,36 & 2,19 & 2,06 & \multirow{3}{*}{$B<A$} \\
\hline & & $\alpha$ & 1,07 & 1,07 & 1,08 & 1,08 & 1,09 & \\
\hline & & $R_{S}$ & 0,45 & 0,57 & 0,59 & 0,63 & 0,72 & \\
\hline \multirow{3}{*}{3} & \multirow{3}{*}{$\mathbf{a}$} & $k_{1}$ & 1,45 & 1,36 & 1,29 & 1,04 & 0,99 & \multirow{3}{*}{$A<B$} \\
\hline & & $\alpha$ & 1,00 & 1,00 & 1,00 & 1,13 & 1,14 & \\
\hline & & $R_{S}$ & 0,00 & 0,00 & 0,00 & 0,59 & 1,05 & \\
\hline \multirow{3}{*}{4} & \multirow{3}{*}{ a } & $k_{1}$ & 1,85 & 1,80 & 1,62 & 1,47 & 1,38 & \multirow{3}{*}{$A<B$} \\
\hline & & $\alpha$ & 1,30 & 1,33 & 1,38 & 1,44 & 1,47 & \\
\hline & & $R_{S}$ & 1,22 & 1,46 & 1,69 & 2,16 & 2,94 & \\
\hline
\end{tabular}

Kromatográfiás körülmények: oszlop, Chirobiotic ${ }^{T M} T A G$; mozgófázis, MeOH/AcOH/TEA (a), 100/0,1/0,1 $(v / v / v)$ és $(\mathbf{b}), 100 / 0,01 / 0,01 v / v / v)$; áramlási sebesség, $0,8 \mathrm{ml} \mathrm{perc}^{-1}$; detektálás, 215 és $220 \mathrm{~nm}$.

Királis elválasztások során általában azt várjuk, hogy a visszatartás és a szelektivitás csökkennek a hőmérséklet növelésével (termodinamikai hatás). A táblázatban összefoglalt adatok szerint a vizsgált aminosavak közül csak az 1 és a 2 vegyületek követték ezt a 
tendenciát MeOH/AcOH/TEA (100/0,01/0,01 v/v/v) mozgófázis alkalmazásakor. Az esetek döntő többségében a szokásostól eltérő viselkedést tapasztaltam, a hőmérséklet növekedésével a csökkenő retenciót egyre nagyobb enantioszelektivitás kísérte $(\mathbf{2}, \mathbf{3}$, illetve 4 komponensek MeOH/AcOH/TEA (100/0,1/0,1 v/v/v) összetételü eluens alkalmazásakor), melynek szemléltetésére a 4 vegyület példáján keresztül a 19. ábra szolgál. Ehhez hasonló rendhagyó viselkedést kutatócsoportunk már megfigyelt nem természetes aminosavak ikerionos állófázisokon végzett elválasztása során [127-129]. További érdekesség, hogy a hőmérséklet emelkedésével az esetek többségében az elválasztás hatékonysága javult.

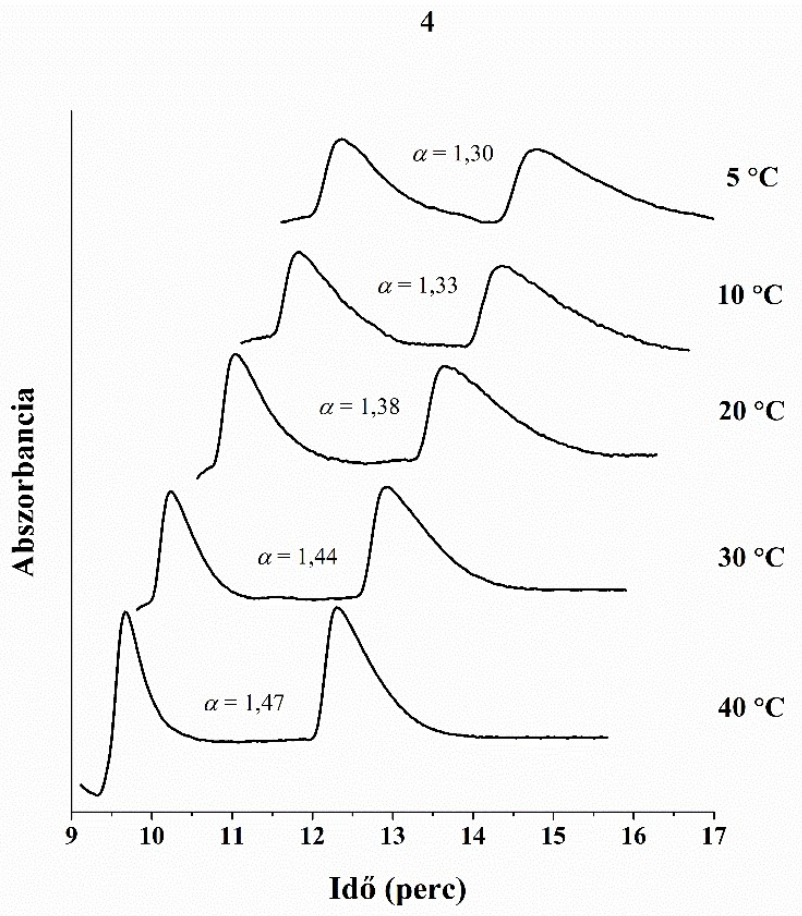

19. ábra A hőmérséklet hatása a 4 vegyület elválasztására Chirobiotic ${ }^{T M} T A G$ oszlopon Kromatográfiás körülmények: oszlop, Chirobiotic ${ }^{T M} T A G$; mozgófázis, MeOH/AcOH/TEA (100/0,1/0,1 $v / v / v)$; áramlási sebesség, $0,8 \mathrm{ml}$ perc ${ }^{-1}$; detektálás, korona kisülési detektor; hömérséklet, $\mathrm{T}=5-40^{\circ} \mathrm{C}$.

A limonénvázas karbociklusos $\beta$-aminosavak elúciós sorrendjét minden esetben megállapítottam. Az alkalmazott Chirobiotic ${ }^{T M} T A G$ és $T$ állófázisokon az 1 és $\mathbf{4}$ minták elúciós sorrendje $A<B$ sorrendben alakult. A 2 vegyület enantiomerjei $B<A$ sorrendben eluálódtak Chirobiotic ${ }^{T M} T A G$ oszlopon (a teikoplanin alapú kolonnán nem voltak elválaszthatók). Ami a 3 vegyületet illeti, $B<A$ elúciós sorrend jellemezte a Chirobiotic $^{T M}$ $T$ kolonnán való elválasztásokat, míg a teikoplanin aglikon szelektor alkalmazásakor fordított sorrendet $(A<B)$ tapasztaltam. A vizsgált enantiomerek eluálódási sorrendjének alakulásában általános tendenciát nem figyeltem meg. Az elválasztott aminosavak 
válogatott, különbözö körülmények között felvett kromatogramjaira a Függelékben mutatok be példákat.

Annak érdekében, hogy megvizsgáljam, a makrociklusos antibiotikum alapú szelektorok alkalmazása során fellépö kölcsönhatások milyen mértékben képesek befolyásolni a királis megkülönböztetést, a 3.4. fejezetben részletesen ismertetett van't Hoff egyenletet felhasználva a vizsgált enantiomerekre kiszámítottam az entalpia-, entrópia- és szabadentalpia-változások különbségeit (4. táblázat).

4. táblázat Termodinamikai adatok, $\Delta\left(\Delta H^{\circ}\right), \Delta\left(\Delta S^{\circ}\right), T \times \Delta\left(\Delta S^{\circ}\right), \Delta\left(\Delta G^{\circ}\right)$, korrelációs koefficiens $\left(R^{2}\right)$ és $Q$ értékei Chirobiotic ${ }^{T M} T A G$ oszlopon

\begin{tabular}{|c|c|c|c|c|c|c|c|}
\hline Vegyület & Mozgófázis & $\begin{array}{c}\text { Korrelációs } \\
\text { koefficiens } \\
\left(R^{2}\right)\end{array}$ & $\begin{array}{c}-\Delta\left(\Delta H^{\circ}\right) \\
\left(\mathbf{k J ~ m o l} \mathbf{l}^{-1}\right)\end{array}$ & $\begin{array}{c}-\Delta\left(\Delta S^{\circ}\right) \\
\left(\mathbf{J ~ m o l}^{-1} \mathbf{K}^{-1}\right)\end{array}$ & $\begin{array}{c}-T \mathrm{~T} \Delta\left(\Delta S^{\circ}\right)_{298 \mathrm{~K}} \\
\left(\mathrm{~kJ} \mathrm{~mol}^{-1}\right)\end{array}$ & $\begin{array}{c}-\Delta\left(\Delta G^{\circ}\right)_{298 K} \\
\left(\mathbf{k J ~ m o l}{ }^{-1}\right)\end{array}$ & $Q$ \\
\hline 1 & b & 0,991 & 2,2 & 6,3 & 1,9 & 0,4 & 1,2 \\
\hline \multirow{2}{*}{2} & $\mathbf{a}$ & 0,991 & $-1,9$ & $-7,2$ & $-2,1$ & 0,2 & 0,9 \\
\hline & b & 0,991 & $-0,4$ & $-6,3$ & $-0,6$ & 0,2 & 0,6 \\
\hline 3 & $\mathbf{a}$ & $0,992 *$ & $-0,5^{*}$ & $-2,8^{*}$ & $-0,8^{*}$ & $0,3^{*}$ & $0,6^{*}$ \\
\hline 4 & $\mathbf{a}$ & 0,995 & $-2,5$ & $-11,3$ & $-3,4$ & 0,8 & 0,8 \\
\hline
\end{tabular}

Kromatográfiás körülmények: oszlop, Chirobiotic ${ }^{T M} T A G$; mozgófázis, MeOH/AcOH/TEA (a), 100/0,1/0,1 $(v / v / v)$ és (b), 100/0,01/0,01 $(v / v / v)$; áramlási sebesség, $0,8 \mathrm{ml} \mathrm{perc}^{-1}$; detektálás, 215 és $220 \mathrm{~nm}$; $R^{2}$, $\ln \alpha$ és $1 / T$ függvény korrelációs koefficiense; $Q=\Delta\left(\Delta H^{\circ}\right) / 298 \times \Delta\left(\Delta S^{\circ}\right)$; hömérséklet tartomány, $\mathrm{T}=5-40{ }^{\circ} \mathrm{C},{ }^{*} \mathrm{~T}=25-40$ ${ }^{\circ} \mathrm{C}$.

Ha megfigyeljük a 4. táblázat adatait, látható, hogy $\Delta\left(\Delta H^{\circ}\right)$ értékei $-2,2$ és $+2,5 \mathrm{~kJ}$ mol $^{-1}$ között változtak. Egyetlen esetet kivéve (1 vegyület) minden vizsgált komponens esetén $\Delta\left(\Delta H^{\circ}\right)$ pozitív volt. $\Delta\left(\Delta S^{\circ}\right)$ értékei hasonló tendencia mentén változtak. Abban az esetben, amikor $\Delta\left(\Delta H^{\circ}\right)$ negatív volt, $\Delta\left(\Delta S^{\circ}\right)$ szintén negatív értéknek adódott, valamint a pozitív $\Delta\left(\Delta H^{\circ}\right)$ pozitív $\Delta\left(\Delta S^{\circ}\right)$ értékekkel járt együtt. Ez utóbbi azon elválasztások esetén volt megfigyelhető, melyeknél a hőmérséklet emelkedését csökkenő retenciós idők és növekvő szelektivitás kísérte. Mindemellett a táblázatban feltüntettem minden egyes vegyület esetén azt az aránypárt $(Q)$, melynek ismeretében jellemezhető, hogy entalpia-, vagy entrópiavezérelt folyamatok játszanak-e nagyobb szerepet a királis felismerés folyamatában. A 4. táblázatban összefoglalt eredmények alapján kijelenthető, hogy $Q$ értéke szinte minden esetben 1-nél kisebb volt, tehát a vizsgált limonénvázas $\beta$-karbonsavak mozgófázisból az állófázisba történő anyagátmenete többnyire entrópiavezérelt folyamat. Ez 
alól az 1 enantiomerpár számított kivételnek $(Q=1,2)$, melyek elválasztása entalpia által vezérelt folyamat az alkalmazott teikoplanin aglikon alapú állófázison. 


\section{2. $N$-metilszubsztituált és amidált ciklusos $\beta$-aminosavak elválasztása ikerionos állófázisokon}

\subsubsection{A mozgófázis összetételének hatása az elválasztásra}

\subsubsection{Eluensösszetétel-változás hatása a kromatográfiás paraméterekre}

A cinkóna alkaloid alapú ioncserélő állófázisok esetén leggyakrabban poláris szerves oldószerelegyeket alkalmaznak mozgófázisként. A $\mathrm{MeOH}$, mint protikus oldószer a poláris komponensek nagymértékü szolvatációja révén csökkenti a retenciót, illetve az ionos kölcsönhatások és H-híd kialakulását az állófázissal. Ezzel szemben az aprotikus karakterü $\mathrm{MeCN}$ alkalmazása jelentős hatást gyakorol a $\pi-\pi$ kölcsönhatások kialakulására, $\mathrm{s}$ egyben elősegíti a H-híd és az ionos kölcsönhatások létrejöttét. Ebből adódóan a két oldószer bizonyos értelemben komplementer viselkedést mutat, azaz a $\mathrm{MeOH} / \mathrm{MeCN}$ arányának változtatásával hangolhatóvá válnak a kromatográfiás tulajdonságok, úgymint a visszatartás és a szelektivitás. A komponensek és a szelektor ionizáltságának befolyásolása és állandó szinten tartása céljából érdemes az eluenshez megfelelő sav és/vagy bázis módosítók adagolása is.

Az $N$-metilszubsztituált és amidált ciklusos $\beta$-aminosavak kromatográfiás vizsgálata során legelöször az eluensösszetétel változtatásának elválasztásra gyakorolt hatását tanulmányoztam $Z W I X(+)$ és $Z W I X(-)$ oszlopokon PI módban, melyhez eluensként nemvizes poláris oldószerek $(\mathrm{MeOH}$ és $\mathrm{MeCN})$ különböző arányú keverékét (80/20, 60/40 és 40/60 $v / v)$ használtam, illetve sav (50 mM FA) és bázis (25 mM TEA) módosítókat állandó koncentrációban (20. ábra). A vizsgált vegyületek elválasztása során a mozgófázis $\mathrm{MeCN}$ tartalmának növekedésével $k_{l}$ értékei rendszerint növekvő tendenciát mutattak. Ez a fentiek tükrében azzal értelmezhető, hogy az ionos vagy ionizálható vegyületeket a nagyobb $\mathrm{MeCN}$ tartalmú mozgófázis kisebb mértékben szolvatálja, ezáltal az elektrosztatikus kölcsönhatások az elválasztani kívánt komponensek és a szelektor között erősebbé válnak, nagyobb mértékü visszatartást eredményezve. Itt szükséges megjegyeznem, hogy az oldószer összetételének megváltoztatásával a sav-bázis egyensúly és a proton aktivitás is megváltozhat, amely a kromatográfiás viselkedés alakulására további hatást gyakorolhat. A tapasztalt retenciós viselkedés mellett a szelektivitás és felbontás kisebb-nagyobb növekedését is megfigyeltem nagy $\mathrm{MeCN}$ tartalmú eluens alkalmazásakor, melyet valószínüleg az erősebb elektrosztatikus kölcsönhatások és H-kötések kialakulása eredményez. 
Amint azt a 20. ábra adatai is érzékeltetik, amikor az MeCN tartalom 20-ról $60 v \%$ ra nőtt, $k_{l}$ értékei enyhén növekvő tendenciát mutattak a 12 és 26 vegyületek elválasztása során $Z W I X(-)$ oszlopon. Hasonló retenciós viselkedés a $Z W I X(+)$ állófázison a 12, 24, 25 és 26 anyagok elválasztására volt jellemző. A szelektivitás értékei általában igen szük tartományban változtak mindkét alkalmazott ioncserélő állófázison. Ez alól kivételt képeztek a 21, 24 és 25 vegyületek a $Z W I X(-)$ oszlopon, illetve a 13 és 21 vegyületek a $Z W I X(+)$ oszlopon, ahol $\alpha$ értékei nagyobb $\mathrm{MeCN}$ tartalom alkalmazása révén monoton növekedést mutattak. A mozgófázis MeCN tartalmának növelésével sok esetben $R_{S}$ értékei is növekedtek. $Z W I X(-)$ oszlopon a 10, 12 és 26, míg $Z W I X(+)$ oszlopon a $\mathbf{1 0}$ és $\mathbf{1 2}$ vegyületek felbontása nem, vagy rendkívül kis mértékben változott. A tapasztalt kromatográfiás viselkedést az alkalmazott oldószer és a vizsgált vegyületek kémiai tulajdonságai alapján értelmezhetjük. Az eluens összetételében az aprotikus jellegű $\mathrm{MeCN}$ arányának növelése csökkenti az ionos, vagy ionizálható modellvegyületek szolvatáltságát, s ezáltal nagyobb lesz a szelektorral való elektrosztatikus kölcsönhatások kialakulásának valószínűsége, mely a kromatográfiás elválasztások során általános tendenciaként nagyobb retenciós időket eredményez. Kutatócsoportunk előzetes tapasztalatai alapján itt szeretném megjegyezni, hogy az eluens MeCN tartalmát nem ajánlatos 60-70 v\% fölé emelni, hiszen az elválasztandó vegyületek retenciós ideje ennél nagyobb MeCN tartalomnál jelentősen megnövekedhet, mely elnyúlt, aszimmetrikus kromatográfiás csúcsokat eredményez.

A bemutatott eredményekre támaszkodva - tekintettel az analízis idejére, illetve a felbontás mértékére - további méréseimet MeOH/MeCN 60/40 v/v összetételü, 25 mM TEA és 50 mM FA módosítót tartalmazó mozgófázissal hajtottam végre a hatékony elválasztások elérése érdekében. 
A)
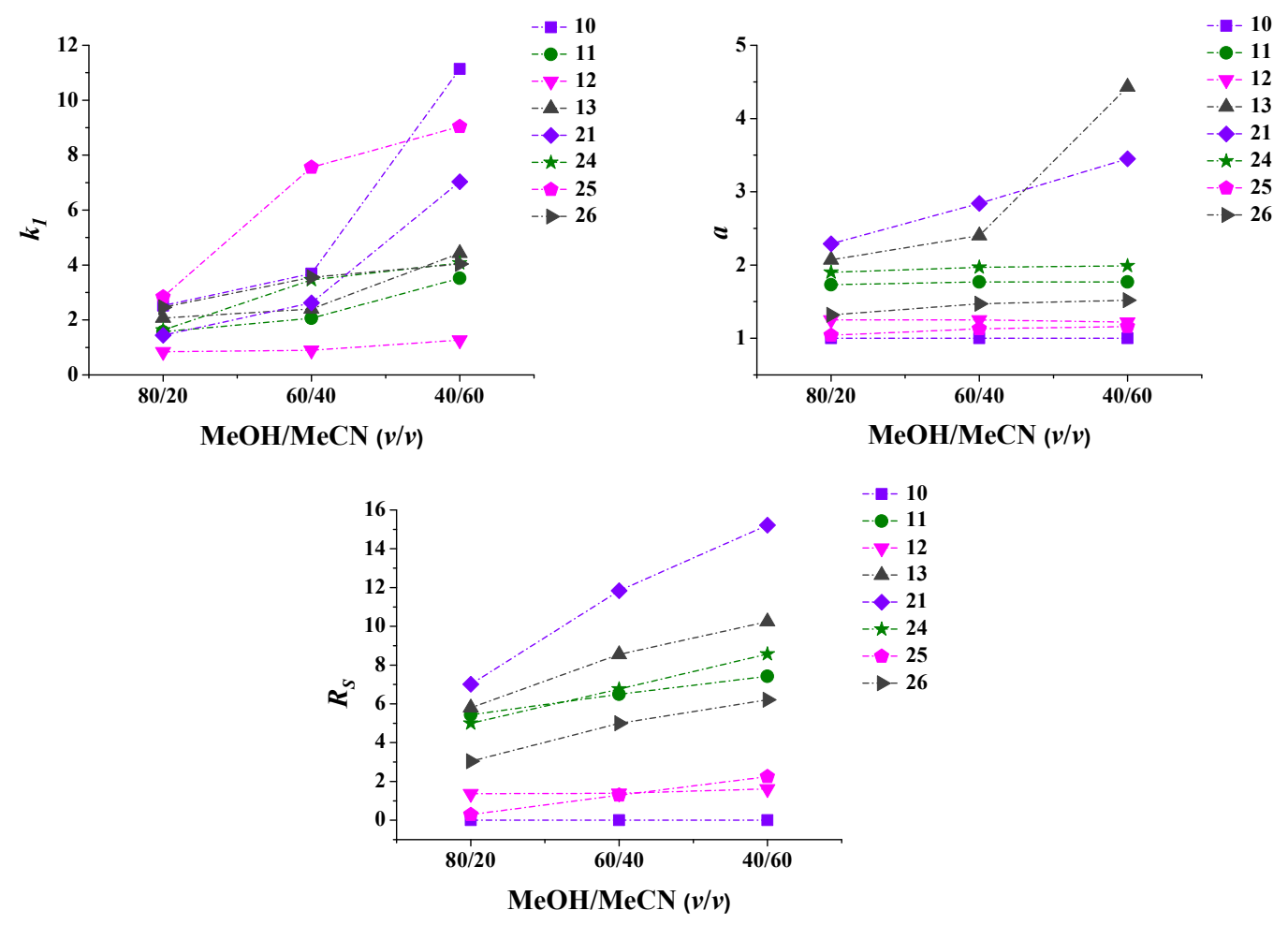

B)
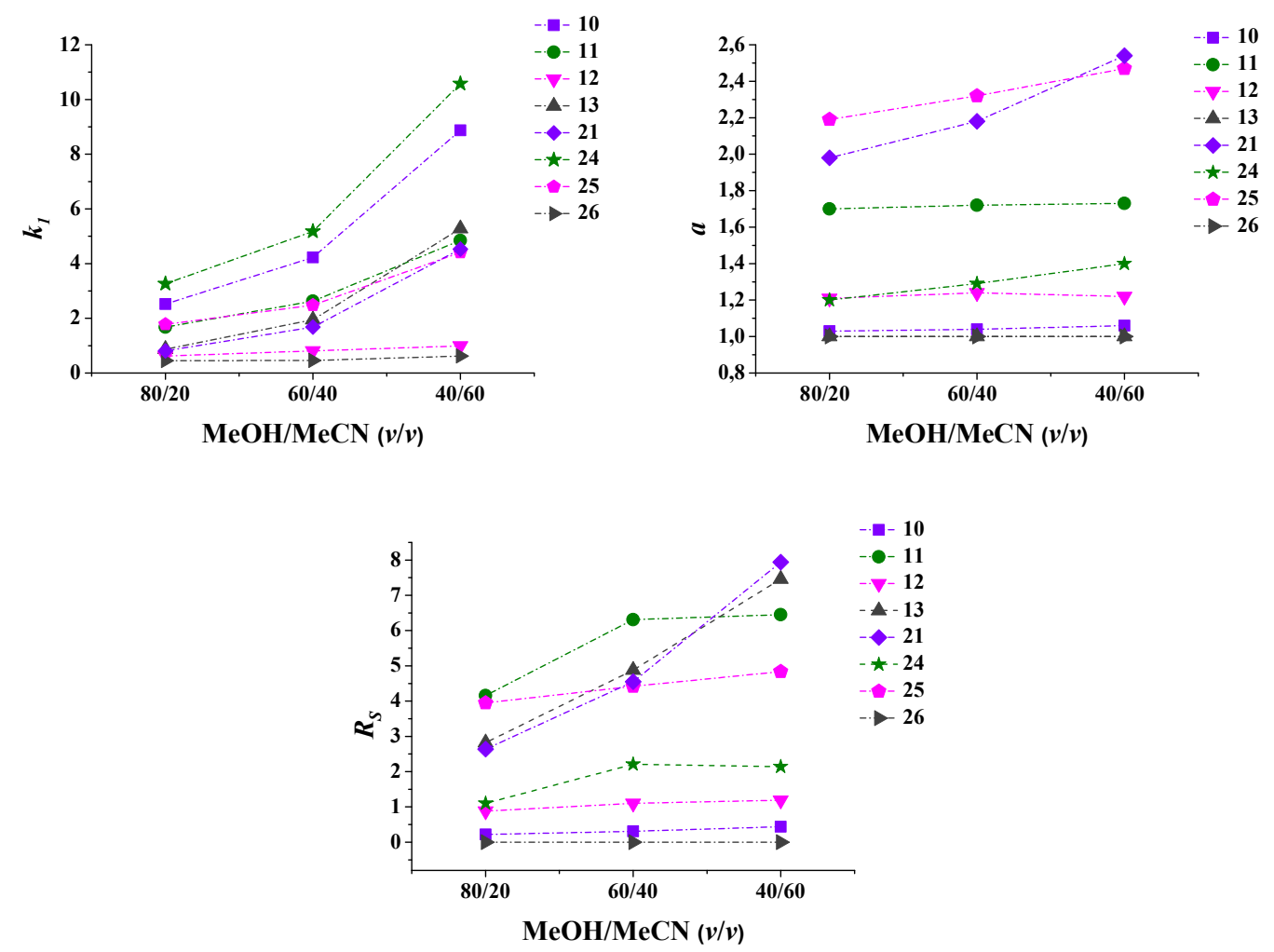

20. ábra A mozgófázis összetételének hatása a kromatográfiás paraméterekre Kromatográfiás körülmények: oszlopok, Chiralpak ${ }^{\circledR} Z W I X(+)$ (A) és $Z W I X(-)$ (B); mozgófázis, $\mathrm{MeOH} / \mathrm{MeCN}(80 / 20,60 / 40,40 / 60 v / v)$ és TEA $(25 \mathrm{mM})$ és FA ( $50 \mathrm{mM})$; áramlási sebesség, $0,6 \mathrm{ml}$ perc $^{-1}$; detektálás, korona kisülési detektor; hömérséklet, $\mathrm{T}=25^{\circ} \mathrm{C}$. 


\subsubsection{Ellen- és kísérőionok koncentrációjának hatása az elválasztásra}

A makrociklusos glikopeptid alapú állófázisokon történő elválasztásoknál már ismertettem, hogy az ellenionok hangsúlyos szerepet töltenek be az elúció szempontjából. A hagyományos kation- vagy anioncserélő állófázisok alkalmazásakor a retenciós tulajdonságok könnyedén szabályozhatók a mozgófázishoz hozzáadott ellenionok koncentrációjának változtatásával. Ilyen esetekben a retenció leírásához a sztöchiometrikus helyettesítési modellt hívhatjuk segítségül [120].

A retenciós mechanizmus mélyebb megértése érdekében az ellenionok koncentrációjának elválasztásra gyakorolt hatását a 10, 11, 12, 13, 18, 19, 20, 21, 22 és 23 vegyületek segítségével vizsgáltam mindkét ikerionos állófázison. A kísérletsorozat végrehajtásánál az FA és a TEA koncentrációját rendre 12,5 mM-ról 200 mM-ig, valamint 6,25 mM-ról $100 \mathrm{mM-ig} \mathrm{növeltem,} \mathrm{míg} \mathrm{a} \mathrm{sav:bázis} \mathrm{arányt} \mathrm{1:2} \mathrm{értéken} \mathrm{tartottam} \mathrm{állandó}$ eluensösszetétel (MeOH/MeCN 60/40 v/v) alkalmazása mellett (21. ábra).

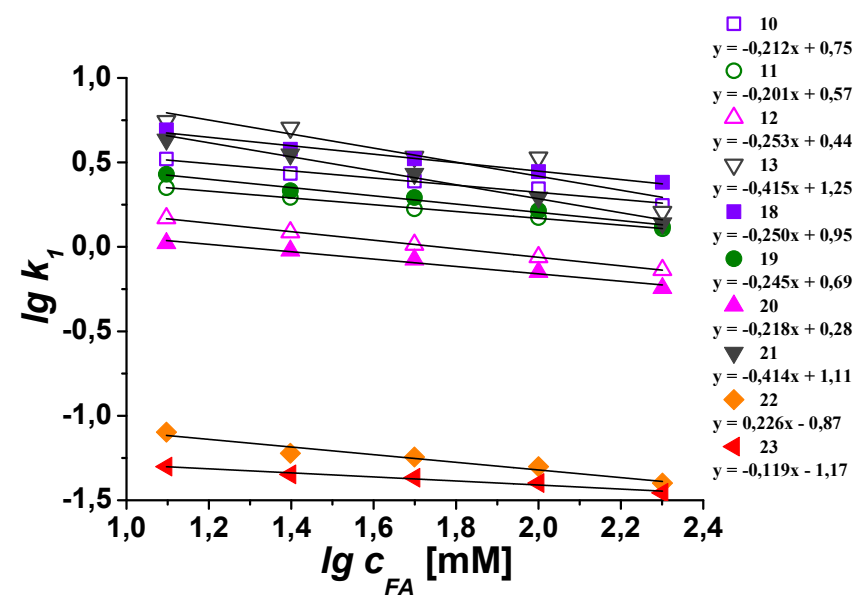

21. ábra Az ellenion koncentrációjának hatása az elsőként eluálódó enantiomer retenciós tényezőjére $\left(k_{1}\right) Z W I X(+)$ oszlopon

Kromatográfiás körülmények: oszlopok, Chiralpak ${ }^{\circledR} Z W I X(+)^{T M}$; mozgófázis, MeOH/MeCN $(60 / 40 v / v)$ és TEA $(6,25-100 \mathrm{mM})$ és FA (12,5-200 mM); áramlási sebesség, 0,6 ml perc ${ }^{1}$; detektálás, korona kisülési detektor; hőmérséklet, $\mathrm{T}=25^{\circ} \mathrm{C}$. 


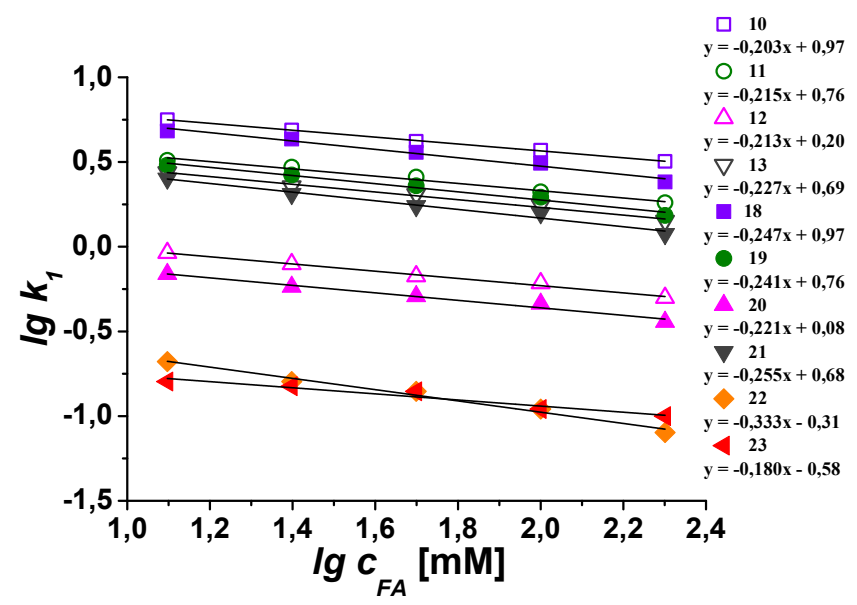

21. ábra (folytatás) Az ellenion koncentrációjának hatása az elsőként eluálódó enantiomer retenciós tényezőjére $\left(k_{1}\right) Z W I X(-)$ oszlopokon

Kromatográfiás körülmények: oszlopok, Chiralpak ${ }^{\circledR} Z W I X(-)^{T M}$; mozgófázis, $\mathrm{MeOH} / \mathrm{MeCN}(60 / 40 v / v)$ és TEA (6,25-100 mM) és FA (12,5-200 mM); áramlási sebesség, 0,6 ml perc ${ }^{1}$; detektálás, korona kisülési detektor; hömérséklet, $\mathrm{T}=25^{\circ} \mathrm{C}$.

Mindkét alkalmazott ikerionos állófázison az ellenionok koncentrációjának növelése csökkenő retenciót eredményezett, mint ahogy az várható volt a sztöchiometrikus helyettesítési modell alapján. A $\lg k_{1}-\lg c_{\text {ellenion }}$ függvények meredeksége abszolút értékben kifejezve $Z W I X(+)$ esetén 0,12-0,42, ZWIX(-) oszlopon pedig 0,18-0,33 volt. Ezen eredmények összhangban vannak kutatócsoportunk szubsztituálatlan és $N$-metilezett karbociklusos $\beta$-aminosavak elválasztásakor tapasztalt megfigyeléseivel, mellyel bizonyítható az elektrosztatikus kölcsönhatási mechanizmus megléte az ikerionos szelektor és az ionos karakterű vegyületek között [124]. Az ellenionok koncentrációjának növekedése során $\alpha$ értékei csekély mértékben változtak (tipikusan néhány \% különbséggel). Ez a megfigyelés ráirányítja a figyelmet az ikerionos állófázisok azon jellezgetes tulajdonságára, miszerint az ellenionok koncentrációjának változtatása révén az elválasztandó komponensek retenciós viselkedése szabályozható az enantioszelektivitás lényeges megváltozása nélkül.

\subsubsection{Az aminocsoport szubsztituáltságának hatása a kromatográfiás viselkedésre}

A kromatográfiás adatok összehasonlításával értékes információkhoz juthatunk a szerkezet és a retenció, valamint a szelektivitás közötti összefüggéseket illetően. A vizsgált ciklusos $\beta$-aminosav származékok meglehetősen eltérő szerkezettel rendelkeznek. Az aminocsoport szubsztituáltságának királis felismerésre gyakorolt hatása mélyebb megértése érdekében az összes sztereoizomer elválasztását egy adott mozgófázis összetétellel $(\mathrm{MeOH} / \mathrm{MeCN} 60 / 40 v / v$ és TEA $(25 \mathrm{mM})$ és FA $(50 \mathrm{mM}))$ tanulmányoztam mindkét ikerionos állófázison (5. táblázat). 
Amint az várható volt, az elválasztani kívánt komponensek aminocsoportjának különböző mértékü szubsztitúciója jelentős hatással van a királis felismerésre. Az aminocsoporton elhelyezkedő szubsztituens méretének - van der Waals térfogatának növekedésével minden esetben a retenció számottevő csökkenését tapasztaltam. Összehasonlítva a szabad aminocsoporttal rendelkező ciklusos $\beta$-aminosavak és a metil-, valamint a dimetilszubsztituált származékok kromatográfiás viselkedését megállapítható, hogy a metilcsoport(ok) jelenléte sztérikus gátlás révén jelentős mértékben járult hozzá a visszatartás csökkenéséhez. Összehasonlítva a monometil- és dimetil analógok kromatográfiás viselkedését, mindkét ikerionos állófázison a két metilcsoporttal rendelkező származékok elválasztását a legtöbb esetben kisebb retenció, de nagyobb szelektivitás jellemezte. Habár a guanidincsoporttal szubsztituált analógok (13 és 21) és a dimetilszubsztituált vegyületek (12 és $\mathbf{2 0}$ ) hasonló van der Waals térfogattal rendelkeznek (5. táblázat), a guanidin származékok elválasztását nagyobb enantioszelektivitás kísérte. A guanidin csoport figyelemreméltó és különleges tulajdonsága tehát, hogy a molekula ionizált karboxilcsoportja és a szelektor protonált aminocsoportja közti elektrosztatikus kölcsönhatás mellett elősegítheti a H-híd kialakulását, ezáltal az elválasztandó komponensek kötődését a szelektor savas részein keresztül. A legkisebb $k_{l}$ értékeket az Fmoc-védett aminosavak (14, 15, 22, 23, 27 és 28) esetén figyeltem meg mindkét alkalmazott ikerionos állófázison, amely nem meglepő, hiszen az aminocsoporton elhelyezkedő Fmoc szubsztituens miatt az ionpár mechanizmus kialakulása nem lehetséges, ami az elválasztás hatékonyságának drasztikus csökkenéséhez vezet. A változatos szerkezettel rendelkező modellvegyületek sztérikus sajátosságai jelentősen befolyásolják a szelektor és az elválasztani kívánt komponensek között létrejövő kölcsönhatásokat. A vizsgált molekulák alapvázát tekintve szembetünő különbség nem jellemezte a kromatográfiás paraméterek alakulását. Mind a ciklopentán-, mind pedig a ciklohexán vázas analógok esetén $k_{l}$ és $\alpha$ értékei hasonló tendencia mentén változtak. Ezzel ellentétben az amino- és karboxilcsoport helyzetét tekintve a cisz és transz konfiguráció határozottan befolyásolta a visszatartást és a szelektivitást. A transz térállású származékok esetén a $k_{l}$ és $\alpha$ értékei nagyobbak voltak mindkét ikerionos ioncserélő kolonna alkalmazása során, mint a cisz konfigurációjú komponensek esetén. Feltehetően a transz izomerek sztérikus elrendeződése kedvezett a szelektor anionos és kationos helyeivel való erősebb mértékü kölcsönhatások kialakulásának. Érdemes megemlíteni, hogy a retenció és a szelektivitás értékeinek alakulása hasonló tendenciát követett a cisz és transz származékok elválasztásakor. 
5. táblázat $N$-metilszubsztituált és amidált ciklusos $\beta$-aminosavak kromatográfiás paraméterei $\left(k_{l}, \alpha, R_{S}\right)$ és az enantiomerek elúciós sorrendje $Z W I X(+)$ és $Z W I X(-)$ oszlopokon

\begin{tabular}{|c|c|c|c|c|c|c|}
\hline Vegyület & $\begin{array}{c}\text { van der Waals } \\
\text { térfogat } \\
{\left[\mathrm{nm}^{3}\right]}\end{array}$ & Oszlop & $\boldsymbol{k}_{1}$ & $\alpha$ & $\boldsymbol{R}_{S}$ & $\begin{array}{l}\text { Elúciós } \\
\text { sorrend }\end{array}$ \\
\hline \multirow{2}{*}{10} & \multirow{2}{*}{22,44} & ZWIX $(+)$ & 4,07 & 1,00 & 0,00 & - \\
\hline & & ZWIX(-) & 4,23 & 1,04 & 0,31 & $1 S, 2 R<1 R, 2 S$ \\
\hline \multirow{2}{*}{11} & \multirow{2}{*}{37,74} & ZWIX $(+)$ & 2,43 & 1,69 & 7,03 & $1 S, 2 R<1 R, 2 S$ \\
\hline & & ZWIX(-) & 2,63 & 1,72 & 6,30 & $1 R, 2 S<1 S, 2 R$ \\
\hline \multirow{2}{*}{12} & \multirow{2}{*}{55,22} & ZWIX $(+)$ & 3,41 & 2,34 & 9,25 & $1 R, 2 S<1 S, 2 R$ \\
\hline & & ZWIX(-) & 2,18 & 2,22 & 5,88 & $1 S, 2 R<1 R, 2 S$ \\
\hline \multirow{2}{*}{13} & \multirow{2}{*}{52,83} & ZWIX $(+)$ & 3,02 & 2,40 & 8,49 & $1 S, 2 R<1 R, 2 S$ \\
\hline & & ZWIX(-) & 1,95 & 2,26 & 4,90 & $1 R, 2 S<1 S, 2 R$ \\
\hline \multirow{2}{*}{14} & \multirow{2}{*}{194,60} & ZWIX(+) & 0,15 & 1,00 & 0,00 & - \\
\hline & & ZWIX(-) & 0,14 & 1,00 & 0,00 & - \\
\hline \multirow{2}{*}{15} & \multirow{2}{*}{211,99} & ZWIX(+) & 0,05 & 1,00 & 0,00 & - \\
\hline & & ZWIX(-) & 0,11 & 1,00 & 0,00 & - \\
\hline \multirow{2}{*}{16} & \multirow{2}{*}{22,44} & ZWIX(+) & 4,51 & 1,14 & 0,95 & $1 R, 2 R<1 S, 2 S$ \\
\hline & & ZWIX(-) & 4,58 & 1,06 & 0,40 & $1 S, 2 S<1 R, 2 R$ \\
\hline \multirow{2}{*}{17} & \multirow{2}{*}{37,74} & ZWIX(+) & 1,98 & 1,37 & 2,19 & $1 R, 2 R<1 S, 2 S$ \\
\hline & & ZWIX(-) & 1,46 & 1,41 & 1,67 & $1 S, 2 S<1 R, 2 R$ \\
\hline \multirow{2}{*}{18} & \multirow{2}{*}{22,44} & ZWIX(+) & 3,79 & 1,19 & 1,42 & $1 R, 2 S<1 S, 2 R$ \\
\hline & & ZWIX(-) & 4,09 & 1,33 & 1,85 & $1 S, 2 R<1 R, 2 S$ \\
\hline \multirow{2}{*}{19} & \multirow{2}{*}{37,74} & ZWIX $(+)$ & 2,17 & 1,50 & 3,17 & $1 S, 2 R<1 R, 2 S$ \\
\hline & & ZWIX(-) & 2,55 & 1,40 & 2,23 & $1 R, 2 S<1 S, 2 R$ \\
\hline \multirow{2}{*}{20} & \multirow{2}{*}{55,22} & ZWIX $(+)$ & 2,75 & 2,63 & 8,65 & $1 R, 2 S<1 S, 2 R$ \\
\hline & & ZWIX(-) & 1,79 & 2,19 & 4,33 & $1 S, 2 R<1 R, 2 S$ \\
\hline \multirow{2}{*}{21} & \multirow{2}{*}{52,83} & ZWIX $(+)$ & 2,62 & 2,84 & 11,90 & $*$ \\
\hline & & ZWIX(-) & 1,68 & 2,18 & 4,57 & $*$ \\
\hline \multirow{2}{*}{22} & \multirow{2}{*}{194,60} & ZWIX $(+)$ & 0,10 & 1,00 & 0,00 & - \\
\hline & & ZWIX(-) & 0,13 & 1,00 & 0,00 & - \\
\hline 23 & 21199 & ZWIX(+) & 0,05 & 1,00 & 0,00 & - \\
\hline 20 & 211,99 & ZWIX(-) & 0,09 & 1,00 & 0,00 & - \\
\hline 24 & 22.44 & ZWIX(+) & 4,83 & 1,10 & 0,64 & $1 R, 2 R<1 S, 2 S$ \\
\hline & & ZWIX(-) & 2,59 & 2,32 & 5,01 & $1 S, 2 S<1 R, 2 R$ \\
\hline & & ZWIX(+) & 2,64 & 1,91 & 5,04 & $1 R, 2 R<1 S, 2 S$ \\
\hline 25 & 31,14 & ZWIX(-) & 2,80 & 2,25 & 5,00 & $1 S, 2 S<1 R, 2 R$ \\
\hline & & ZWIX $(+)$ & 0,81 & 1,11 & 0,56 & $1 R, 2 R<1 S, 2 S$ \\
\hline 20 & 35,22 & ZWIX(-) & 0,58 & 1,00 & 0,00 & - \\
\hline 27 & 194,60 & ZWIX(+) & 0,10 & 1,00 & 0,00 & - \\
\hline 21 & 194,00 & ZWIX(-) & 0,07 & 1,00 & 0,00 & - \\
\hline 28 & 211,99 & ZWIX $(+)$ & 0,06 & 1,00 & 0,00 & - \\
\hline & & ZWIX(-) & 0,10 & 1,00 & 0,00 & - \\
\hline
\end{tabular}

Kromatográfiás körülmények: oszlopok, Chiralpak ${ }^{\circledR} Z W I X(+)$ és $Z W I X(-)$; mozgófázis, MeOH/MeCN (60/40 $v / v)$ és $25 \mathrm{mM}$ TEA és $50 \mathrm{mM} \mathrm{FA}$; áramlási sebesség, $0,6 \mathrm{ml} \mathrm{perc}^{-1}$; detektálás, korona kisülési detektor; hömérséklet, $\mathrm{T}=25^{\circ} \mathrm{C}$. Az aminocsoporton található szubsztituensek van der Waals térfogatait MarvinSketch v. 17.28 szoftverrel határoztam meg. *nincs elúciós sorrend meghatározás 
Összevetve a két ikerionos állófázist, az analízisek döntő többségében a ZWIX(-) oszlop szelektívebbnek bizonyult a vizsgált ciklusos $\beta$-aminosavak elválasztásában nagyobb $k_{1}, \alpha$ és $R s$ értékeket eredményezve. Azonban az $N$-amidált származékok (13 és 21 vegyület) esetén a $Z W I X(+)$ állófázis biztosított hatékonyabb elválasztást.

Korábban már kifejtettem az ioncserélő típusú királis állófázisok kapcsán, hogy a kinin és kinidin szelektorokat tartalmazó $Z W I X(+)$ és $Z W I X(-)$ oszlopok esetén a cinkóna alapvázhoz a C-9 királis szénatomhoz karbamát-kötéssel egy transz-2-aminociklohexánszulfonsav egység kapcsolódik, mely ily módon erős kationcserélő részként viselkedik. Mivel a két szelektor esetén nem minden királis atom ellentétes konfigurációjú, így a kinin és a kinidin diasztereomer viszonyban állnak egymással. Ezzel szemben a királis felismerés szempontjából meghatározó jelentőséggel bíró aszimmetrikus szénatomok ellentétes térállásúak. Ezen igen előnyös tulajdonságukból fakadóan az elválasztandó enantiomerek elúciós sorrendje az oszlopok cseréjével sok esetben megfordítható [130]. Méréseim minden esetben bizonyítékul szolgáltak az ellentétes elúciós sorrend kialakulására, természetesen amikor az elválasztás megvalósítható volt (5. táblázat). A 10 anyag a $Z W I X(+)$, a 26 vegyület a $Z W I X(-)$, míg az Fmoc-védett aminosavak enantiomerei egyik alkalmazott ioncseréló állófázissal sem voltak elválaszthatók az alkalmazott kromatográfiás körülmények között. A racém cisz-ciklohexán vázzal rendelkező guanidinszármazék (21) esetén nem állt rendelkezésre tiszta enantiomer, így az elúció sorrendjét nem tudtam megállapítani. Az ikerionos állófázisokon végzett elválasztásokra a Függelékben mutatok be néhány jellegzetes, kiragadott példát. 


\subsubsection{A hőmérséklet hatása és termodinamikai paraméterek}

Annak érdekében, hogy átfogó képet kapjak a hőmérséklet elválasztásra gyakorolt hatásáról a vizsgált ciklusos $\beta$-aminosav származékok esetén, az oszlop hőmérsékletét 5-40 ${ }^{\circ} \mathrm{C}$ tartományban változtatva tanulmányoztam a kromatográfiás jellemzők alakulását $Z W I X(+)$ és $Z W I X(-)$ oszlopokon. A 10, 11, 12, 13, 18, 19, 20, 21, 24 és 25 vegyületek részleges és alapvonalon történő elválasztását sikeresen megvalósítottam $\mathrm{MeOH} / \mathrm{MeCN}$ $60 / 40 v / v$ és TEA (25 mM) és FA $(50 \mathrm{mM})$ eluensrendszer alkalmazásával, melynek eredményeit a 6. táblázat foglaltam össze.

6. táblázat Különböző hömérsékleten mért kromatográfiás paraméterek $\left(k_{1}, \alpha, R_{S}\right)$ értékei $Z W I X(+)$ és $Z W I X(-)$ oszlopokon

\begin{tabular}{|c|c|c|c|c|c|c|c|}
\hline \multirow{2}{*}{ Vegyület } & \multirow{2}{*}{ Oszlop } & \multirow{2}{*}{$\begin{array}{l}k_{l}, \\
\alpha, \\
R_{S}\end{array}$} & \multicolumn{5}{|c|}{ Hőmérséklet $\left({ }^{\circ} \mathbf{C}\right)$} \\
\hline & & & 5 & 10 & 20 & 30 & 40 \\
\hline \multirow{3}{*}{10} & \multirow{3}{*}{ ZWIX(-) } & $k_{1}$ & 3,41 & 3,54 & 3,64 & 3,82 & 3,96 \\
\hline & & $\alpha$ & 1,02 & 1,03 & 1,05 & 1,06 & 1,08 \\
\hline & & $R_{S}$ & 0,00 & 1,03 & 1,03 & 1,07 & 1,08 \\
\hline \multirow{6}{*}{11} & \multirow{3}{*}{ ZWIX(+) } & $k_{1}$ & 2,43 & 2,34 & 2,23 & 2,11 & 1,98 \\
\hline & & $\alpha$ & 1,86 & 1,79 & 1,72 & 1,65 & 1,60 \\
\hline & & $R_{S}$ & 6,32 & 5,36 & 5,16 & 5,43 & 4,79 \\
\hline & \multirow{3}{*}{ ZWIX(-) } & $k_{1}$ & 2,67 & 2,65 & 2,54 & 2,52 & 2,44 \\
\hline & & $\alpha$ & 1,78 & 1,77 & 1,71 & 1,64 & 1,59 \\
\hline & & $R_{S}$ & 4,62 & 4,80 & 4,47 & 4,32 & 4,12 \\
\hline \multirow{6}{*}{12} & \multirow{3}{*}{ ZWIX(+) } & $k_{1}$ & 1,14 & 1,11 & 1,06 & 0,99 & 0,94 \\
\hline & & $\alpha$ & 1,30 & 1,29 & 1,26 & 1,25 & 1,23 \\
\hline & & $R_{S}$ & 1,62 & 1,67 & 1,40 & 1,39 & 1,39 \\
\hline & \multirow{3}{*}{ ZWIX(-) } & $k_{1}$ & 0,77 & 0,81 & 0,72 & 0,72 & 0,68 \\
\hline & & $\alpha$ & 1,25 & 1,25 & 1,25 & 1,26 & 1,26 \\
\hline & & $R_{S}$ & 0,92 & 1,02 & 1,16 & 1,07 & 1,13 \\
\hline \multirow{6}{*}{13} & \multirow{3}{*}{ ZWIX(+) } & $k_{1}$ & 3,59 & 3,67 & 3,47 & 3,41 & 3,38 \\
\hline & & $\alpha$ & 2,60 & 2,56 & 2,41 & 2,34 & 2,22 \\
\hline & & $R_{S}$ & 10,33 & 9,95 & 9,22 & 9,25 & 8,90 \\
\hline & \multirow{3}{*}{ ZWIX(-) } & $k_{1}$ & 1,66 & 2,05 & 2,10 & 2,18 & 2,25 \\
\hline & & $\alpha$ & 2,37 & 2,33 & 2,28 & 2,22 & 2,16 \\
\hline & & $R_{S}$ & 4,46 & 5,69 & 5,79 & 5,88 & 5,99 \\
\hline \multirow{3}{*}{18} & \multirow{3}{*}{ ZWIX(+) } & $k_{1}$ & 3,98 & 3,93 & 3,87 & 3,62 & 3,36 \\
\hline & & $\alpha$ & 1,22 & 1,21 & 1,20 & 1,19 & 1,18 \\
\hline & & $R_{S}$ & 1,23 & 1,23 & 1,67 & 1,47 & 1,44 \\
\hline
\end{tabular}

Kromatográfiás körülmények: oszlopok, Chiralpak ${ }^{\circledR} Z W I X(+)$ és $Z W I X(-)$; mozgófázis, MeOH/MeCN (60/40 $v / v$ ) és $25 \mathrm{mM}$ TEA és $50 \mathrm{mM} \mathrm{FA}$; áramlási sebesség, $0,6 \mathrm{ml} \mathrm{perc}^{-1}$; detektálás, RI detektor, $265 \mathrm{~nm}$ és korona kisülési detektor. 
6. táblázat (folytatás) Különböző hőmérsékleten mért kromatográfiás paraméterek $\left(k_{l}, \alpha, R_{S}\right)$ értékei $Z W I X(+)$ és $Z W I X(-)$ oszlopokon

\begin{tabular}{|c|c|c|c|c|c|c|c|}
\hline \multirow{2}{*}{ Vegyület } & \multirow{2}{*}{ Oszlop } & \multirow{2}{*}{$\begin{array}{c}k_{1}, \\
\alpha, \\
R_{S}\end{array}$} & \multicolumn{5}{|c|}{ Hőmérséklet $\left({ }^{\circ} \mathbf{C}\right)$} \\
\hline & & & 5 & 10 & 20 & 30 & 40 \\
\hline \multirow{3}{*}{19} & \multirow{3}{*}{ ZWIX(+) } & $k_{1}$ & 2,28 & 2,31 & 2,20 & 2,09 & 2,15 \\
\hline & & $\alpha$ & 1,63 & 1,60 & 1,54 & 1,47 & 1,39 \\
\hline & & $R_{S}$ & 4,00 & 3,58 & 3,14 & 3,00 & 2,96 \\
\hline \multirow{3}{*}{20} & \multirow{3}{*}{ ZWIX(+) } & $k_{1}$ & 1,01 & 1,00 & 0,93 & 0,88 & 0,90 \\
\hline & & $\alpha$ & 1,14 & 1,14 & 1,13 & 1,11 & 1,10 \\
\hline & & $R_{S}$ & 0,67 & 0,62 & 0,53 & 0,40 & 0,53 \\
\hline \multirow{6}{*}{21} & \multirow{3}{*}{ ZWIX(+) } & $k_{1}$ & 2,80 & 2,78 & 2,76 & 2,75 & 2,73 \\
\hline & & $\alpha$ & 3,05 & 3,05 & 2,83 & 2,63 & 2,55 \\
\hline & & $R_{S}$ & 10,03 & 11,30 & 11,37 & 8,65 & 9,29 \\
\hline & \multirow{3}{*}{ ZWIX(-) } & $k_{1}$ & 1,37 & 1,60 & 1,69 & 1,79 & 1,90 \\
\hline & & $\alpha$ & 2,36 & 2,32 & 2,26 & 2,19 & 2,11 \\
\hline & & $R_{S}$ & 3,54 & 4,17 & 4,23 & 4,33 & 4,33 \\
\hline \multirow{3}{*}{24} & \multirow{3}{*}{ ZWIX(-) } & $k_{1}$ & 5,43 & 5,39 & 5,41 & 5,33 & 5,18 \\
\hline & & $\alpha$ & 1,35 & 1,33 & 1,32 & 1,30 & 1,29 \\
\hline & & $R_{S}$ & 1,85 & 2,11 & 1,92 & 1,93 & 1,94 \\
\hline \multirow{3}{*}{25} & \multirow{3}{*}{ ZWIX(-) } & $k_{1}$ & 2,85 & 2,85 & 2,77 & 2,71 & 2,60 \\
\hline & & $\alpha$ & 2,57 & 2,49 & 2,35 & 2,22 & 2,12 \\
\hline & & $R_{S}$ & 6,00 & 6,73 & 6,75 & 6,89 & 7,60 \\
\hline
\end{tabular}

Kromatográfiás körülmények: oszlopok, Chiralpak ${ }^{\circledR} Z W I X(+)$ és $Z W I X(-)$; mozgófázis, $\mathrm{MeOH} / \mathrm{MeCN}(60 / 40$ $v / v)$ és $25 \mathrm{mM}$ TEA és $50 \mathrm{mM} \mathrm{FA}$; áramlási sebesség, $0,6 \mathrm{ml} \mathrm{perc}^{-1}$; detektálás, RI detektor, $265 \mathrm{~nm}$ és korona kisülési detektor.

A legtöbb modellvegyület elválasztásakor a retenció csökkent a hőmérséklet növekedésével, tehát az eluensben oldott komponensek mozgófázisból az állófázisba történő átjutását az esetek döntő többségében exoterm folyamat kísérte. Kivétel volt ez alól, amikor a hőmérséklet emelkedését növekvő $k_{l}$ érték kísérte a 10, 13 és 21 anyagok $Z W I X(-)$ oszlopon történő elválasztása során. A szelektivitás értékei a retencióhoz hasonlóan csökkentek a hőmérséklet emelkedésével, de itt is adódtak kivételek, szintén a ZWIX(-) oszlopon: magasabb hőmérsékletet alkalmazva a $\mathbf{1 0}$ enantiomerpár elválasztását az enantioszelektivitás csekély növekedése kísérte. A felbontás általában csökkent a hőmérséklet emelésével mindkét ioncserélő állófázison, ugyanakkor a 10, 12, 13, 21 és 25 anyagok elválasztásakor a $Z W I X(-)$ oszlopon meghatározott $R_{S}$ értékeiben szembetűnő javulást fedeztem fel. 
A van't Hoff egyenletet alapján kiszámolt termodinamikai paramétereket a 7 . táblázat tartalmazza. $\Delta\left(\Delta H^{\circ}\right)$ értékei $-4,2$ és $-0,7 \mathrm{~kJ} \mathrm{~mol}^{-1}$ értéktartományban változtak $Z W I X(+)$, míg -4,1 és $+1,2 \mathrm{~kJ} \mathrm{~mol}^{-1}$ között $Z W I X(-)$ oszlopon. $\Delta\left(\Delta S^{\circ}\right)$ értéke a $Z W I X(+)$

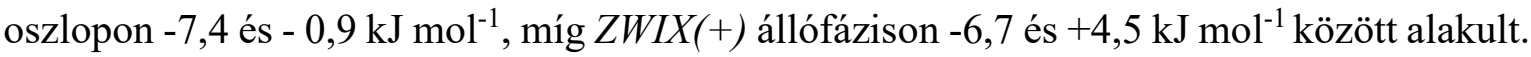
A kiszámolt termodinamikai adatok alapján megállapítható, hogy a makrociklusos antibiotikum alapú állófázisokon tapasztaltakhoz hasonlóan itt is a negatív $\Delta\left(\Delta H^{\circ}\right)$ negatív $\Delta\left(\Delta S^{\circ}\right)$ értékkel járt, pozitív $\Delta\left(\Delta H^{\circ}\right)$ esetén pedig pozitív $\Delta\left(\Delta S^{\circ}\right)$ értékeket kaptam. A kiszámolt $Q$ értékeket megvizsgálva kijelenthető, hogy a tanulmányozott vegyületcsalád elválasztása döntően entalpiavezérelt folyamat volt $(Q>1)$. Azonban megfigyeltem entrópia által vezérelt elválasztást is a cisz-ciklopentán szubsztituálatlan (10 vegyület; $Q=0,9)$, valamint guanidincsoporttal szubsztituált ciklusos $\beta$-aminosav (13 vegyület; $Q=0,4)$ enantiomerek esetén $Z W I X(-)$ állófázis alkalmazásakor.

7. táblázat Termodinamikai paraméterek, $\Delta\left(\Delta H^{\circ}\right), \Delta\left(\Delta S^{\circ}\right)$, Tx $\Delta\left(\Delta S^{9}\right), \Delta\left(\Delta G^{\circ}\right)$, korrelációs koefficiens, $\left(R^{2}\right)$ és $Q$ értékek $Z W I X(-)$ és $Z W I X(+)$ oszlopokon

\begin{tabular}{|c|c|c|c|c|c|c|}
\hline Vegyület & $\begin{array}{c}-\Delta\left(\Delta H^{\circ}\right) \\
\left(k^{\prime} ~ m o l^{-1}\right)\end{array}$ & $\begin{array}{c}-\Delta(\Delta S 9) \\
\left(\mathrm{J} \mathrm{mol}^{-1} \mathrm{~K}^{-1}\right)\end{array}$ & $\begin{array}{c}\text { Korrelációs } \\
\text { koefficiens }\left(R^{2}\right)\end{array}$ & $\begin{array}{c}-\mathrm{Tx} \Delta\left(\Delta S \mathrm{~g}_{298 K}\right. \\
\quad\left(\mathrm{kJ} \mathrm{mol}^{-1}\right)\end{array}$ & $\begin{array}{c}-\Delta(\Delta G)_{298 \mathrm{~K}} \\
\left(\mathbf{k J ~ m ^ { - 1 }}\right)\end{array}$ & $Q$ \\
\hline \multicolumn{7}{|c|}{ ZWIX(+) } \\
\hline 11 & 3,0 & 5,8 & 0,986 & 1,7 & 1,3 & 1,7 \\
\hline 12 & 3,3 & 3,9 & 0,989 & 1,2 & 2,1 & 2,8 \\
\hline 13 & 1,2 & 1,9 & 0,960 & 0,6 & 0,6 & 2,0 \\
\hline 18 & 0,7 & 0,9 & 0,998 & 0,3 & 0,4 & 2,3 \\
\hline 19 & 3,2 & 7,4 & 0,989 & 2,2 & 1,0 & 1,5 \\
\hline 20 & 4,2 & 5,7 & 0,979 & 1,7 & 2,5 & 2,5 \\
\hline 21 & 0,9 & 2,0 & 0,980 & 0,6 & 0,3 & 1,5 \\
\hline \multicolumn{7}{|c|}{ ZWIX(-) } \\
\hline 10 & $-1,2$ & $-4,5$ & 0,998 & $-1,3$ & 0,1 & 0,9 \\
\hline 11 & 2,5 & 4,3 & 0,992 & 1,3 & 1,3 & 1,9 \\
\hline 12 & 2,1 & 0,4 & 0,977 & 0,1 & 2,0 & 21 \\
\hline 13 & $-0,3$ & $-2,8$ & 0,988 & $-0,8$ & 0,6 & 0,4 \\
\hline 21 & 2,3 & 0,9 & 0,992 & 0,1 & 2,0 & 23 \\
\hline 24 & 0,9 & 0,8 & 0,995 & 0,2 & 0,7 & 4,5 \\
\hline 25 & 4,1 & 6,7 & 0,999 & 2,0 & 2,1 & 2,1 \\
\hline
\end{tabular}

Kromatográfiás körülmények: oszlopok, Chiralpak ${ }^{\circledR} Z W I X(+)$ és $Z W I X(-)$; mozgófázis, MeOH/MeCN (60/40 $v / v$ ) és $25 \mathrm{mM}$ TEA és $50 \mathrm{mM}$ FA; áramlási sebesség, $0,6 \mathrm{ml}$ perc ${ }^{-1}$, detektálás, koronakisülési detektor; $R^{2}$, ln $\alpha$ és $1 / T$ függvények korrelációs koefficiense; $Q=\Delta\left(\Delta H^{\circ}\right) / 298 \times \Delta\left(\Delta S^{\circ}\right)$; hőmérséklettartomány, $\mathrm{T}=5-40^{\circ} \mathrm{C}$. 


\subsection{Limonén alapú biciklusos aminoalkoholok és aminodiolok elválasztása poliszacharid alapú állófázisokon NP-LC és SFC technikák alkalmazásával}

A Waters Kft. (Budapest, Magyarország) 2018-2019 időszakban a kutatócsoport számára lehetőséget biztosított egy Acquity $\mathrm{UPC}^{2} \mathrm{SFC}$ rendszer alkalmazására. A limonén alapú biciklusos aminoalkohol és aminodiol analógok normál fázisú folyadékkromatográfiás vizsgálata során a modellvegyületek folyadékkromatográfiás elválasztásának optimalizálása mellett a két elválasztástechnika analitikai teljesítöképességének összehasonlítását is célul tüztem ki. Ebben a fejezetben a két kromatográfiás technikával végzett elválasztások során elért eredményeimet, s azok értékelését mutatom be.

\subsubsection{A mozgófázis összetevőinek hatása az elválasztásra}

\subsubsection{A mozgófázist alkotó alkohol anyagi minőségének hatása}

A poliszacharid alapú királis állófázisokat legelterjedtebben NP körülmények között alkalmazzák, melynek során valamely apoláris oldószer (pl. hexán, heptán), valamint kis molekulatömegü alkohol (pl. 1-PrOH, 2-PrOH, EtOH, BuOH, $t-\mathrm{BuOH}$ ) elegye szolgál mozgófázisként [68, 131-133]. A visszatartás és a szelektivitás szabályozására NP-LC [134136] és SFC alkalmazása során [137-140] az eluenst alkotó alkohol minőségének változtatásával nyílik lehetőség. Az alkohol anyagi minőségének kromatográfiás paraméterekre gyakorolt hatását a 6 (aminoalkohol) és 8 (aminodiol) modellvegyületek (mint a vizsgált vegyületek egy-egy reprezentáns képviselője) esetén tanulmányoztam Lux Amylose-2 és Lux i-Cellulose-5 állófázisokon. Az alkalmazott alkohol adalékok NP-LC módban EtOH, 1-PrOH, 2-PrOH, BuOH, $t$-BuOH, míg SFC módban $\mathrm{MeOH}$, EtOH, 1-PrOH és 2-PrOH voltak. A vizsgált vegyületek elválasztása során megfigyelt kromatográfiás adatokat a 22. ábrán foglaltam össze. 
A)

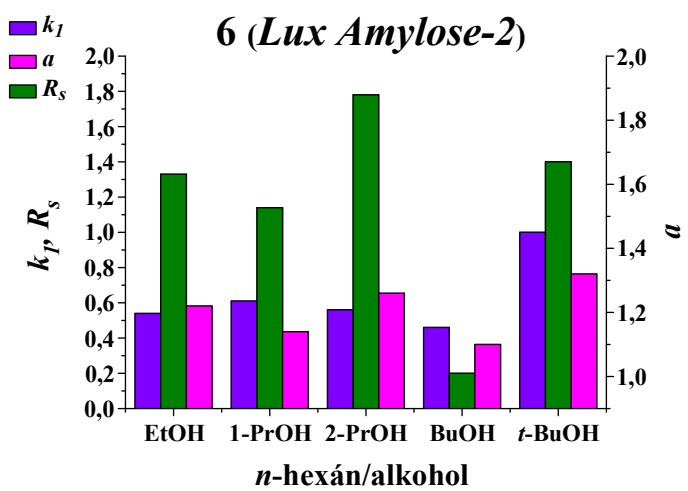

C)

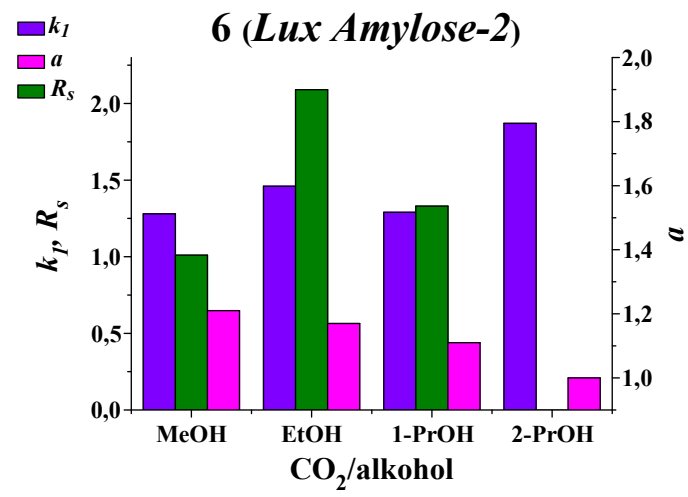

B)

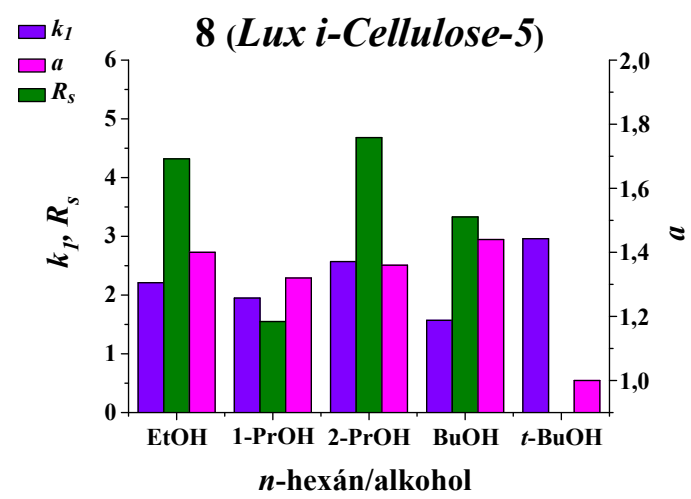

D)

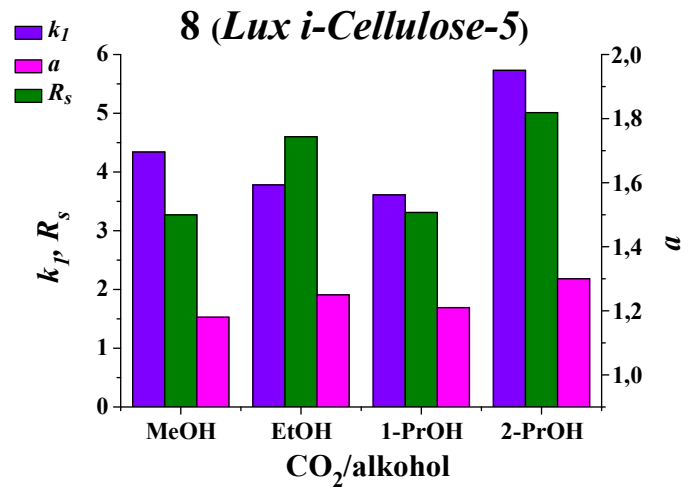

22. ábra Az alkohol anyagi minőségének kromatográfiás paraméterekre gyakorolt hatása Lux Amylose-2 és Lux i-Cellulose-5 állófázisokon NP-LC (A, B) és SFC (C, D) módban Kromatográfiás körülmények: oszlopok, Lux Amylose-2 és Lux i-Cellulose-5; mozgófázis, A) és B), $n$ hexán/alkohol/DEA, alkohol tartalom 0,13 M (EtOH, 7,6 v\%; 1-PrOH, 9,7 v\%; 2-PrOH, $10 v \%$; BuOH, 11,9 $v \%$; $t$ - $\mathrm{BuOH}, 12,4 \%$ ) és DEA tartalom $0,1 v \%, \mathbf{C})$ és $\mathbf{D}), \mathrm{CO}_{2} /$ alkohol $(80 / 20 v / v)$ és DEA $(20 \mathrm{mM})$; áramlási sebesség, A) és B), 1,0 ml perc ${ }^{-1}$ C) és D), 2,0 $\mathrm{ml}^{\text {perc }}$; detektálás, 210 és $260 \mathrm{~nm}$; hömérséklet, A) és $\mathbf{B}$ ), $\mathrm{T}=25^{\circ} \mathrm{C}, \mathbf{C}$ ) és $\left.\mathbf{D}\right), 40^{\circ} \mathrm{C}$; ellennyomás, C) és D), 150 bar.

Normál fázisú HPLC körülmények között a kromatográfiás paraméterek alkoholfüggésének vizsgálatához az alkalmazott alkohol adalékokat állandó moláris koncentrációban (1,3 M) alkalmaztam (ez megfelel EtOH 7,6 v\%, 1-PrOH 9,7 v\%, 2-PrOH $10 \nu \%, \mathrm{BuOH} 11,9 v \%, t$-BuOH 12,4 $v \%$ százalékos mennyiségének). Ilyen körülmények között a kevésbé poláris alkohol módosítók használata általában a vizsgált komponensek nagyobb visszatartását eredményezte. Az alkohol szénlánc hosszának növekedésével (azaz polaritásának csökkenésével) $k_{1}$ értékei enyhe növekedést mutattak, amely arra enged következtetni, hogy a limonén vázas aminoalkohol és aminodiol analógok szolvatációja ezekben az oldószerekben csökkent és inkább az állófázishoz kötődtek jobban, mint a mozgófázishoz. Néhány esetben azonban ezzel ellentétes viselkedést tapasztaltam, amit más 
tanulmányok során is megfigyeltek, például Sardella, valamint Wang és munkatársai [141, 142]. A szelektivitás csekély mértékben változott az alkohol anyagi minőségének változtatásával, míg $R_{s}$ értékei $2-\mathrm{PrOH}$ (vagy EtOH) alkalmazása esetén adódtak a legnagyobbnak. Irodalmi adatok szerint a poliszacharid alapú állófázisokkal történő elválasztások során az elúció sorrendje eltérő koncentrációjú és minőségű alkoholokat alkalmazva megváltozhat [134-136]. A vizsgált aminoalkohol és aminodiol származékok elválasztásakor a különböző anyagi minőségü alkohol adalékok alkalmazása során nem tapasztaltam az elúció sorrendjében változást. Az elúciós sorrendet minden esetben meghatároztam, mellyel kapcsolatos vizsgálataimra később részletesebben ki fogok térni.

SFC-vel végzett analízisek során a visszatartás hasonlóan alakult az NP-LC mérések során tapasztalt retenciós viselkedéshez, hiszen $k_{l}$ értékeiben növekedö tendenciát figyeltem meg az alkalmazott alkoholok szénlánc hosszának növelésével (22. ábra). Lux Amylose-2 állófázison a 6 minta esetén a szelektivitás enyhén csökkent, míg a 8 vegyület esetében a Lux i-Cellulose-5 oszlopon $\alpha$ értékei enyhe növekedést mutattak az alkohol polaritásának csökkenésével párhuzamosan. Hasonlóan az NP-LC körülmények között tapasztaltakhoz, az SFC elválasztások során sem változott meg az enantiomerek elúciós sorrendje. NP-LC módban tehát 2-PrOH, míg SFC technika alkalmazása során MeOH biztosította a limonén vázzal rendelkező biciklusos aminoalkoholok és aminodiolok leghatékonyabb elválasztását. Ezen eredményekre támaszkodva a későbbi kísérletek során ilyen alkohol tartalmú mozgófázis elegyeket alkalmaztam.

\subsubsection{Az eluensösszetétel-változás hatása a kromatográfiás paraméterekre}

A mozgófázis összetételének hatását szintén a 6 és 8 vegyületek esetén vizsgáltam NP-LC és SFC technikát egyaránt alkalmazva. A limonénvázas analógok enantioszelektív elválasztását NP-LC módban $n$-hexán/2-PrOH/DEA, SFC módban pedig $\mathrm{CO}_{2} / \mathrm{MeOH}$ és DEA (25 mM) eluensösszetétellel valósítottam meg. Kutatócsoportunk korábbi tapasztalatai alátámasztják, hogy a klórszubsztituált cellulóz- és amilóz alapú állófázisok eredményesnek bizonyulnak a különböző enantioszelektív elválasztások során [143-145], ezért a kísérletsorozat végrehajtásához amilóz trisz-(5-klór-2-metilfenilkarbamát) (Lux Amylose-2), illetve cellulóz trisz-(3,5-diklórfenilkarbamát) ( Lux i-Cellulose-5) szelektorokkal rendelkező állófázisokat választottam (23. ábra). 
Ami a retenciót illeti, mindkét alkalmazott technikánál tipikus normál fázisú kromatográfiás viselkedést tapasztaltam. Ez azt jelenti, hogy az apoláris $n$-hexán vagy $\mathrm{CO}_{2}$ tartalom növelése az eluensben növekvő $k_{1}$ értékeket eredményezett, kiváltképp a $L u x i$ Cellulose-5 oszlopon (23. ábra). NP-LC módban csekély (Lux Amylose-2) és mérsékelt (Lux i-Cellulose-5) növekedés jellemezte a szelektivitást a 6 vegyület esetén 90/10 v/v n-hexán/2PrOH összetételig, míg a 8 anyag elválasztása Lux Amylose-2 oszlopon eredménytelen volt. SFC módban $\alpha$ enyhén változott a $\mathrm{MeOH}$ tartalom változtatásával, míg a 6 vegyület esetén Lux Amylose-2 kolonnán a $\mathrm{CO}_{2} / \mathrm{MeOH}(90 / 10 v / v)$ összetétel volt alkalmas az enantiomerek optimális elválasztásához. A legtöbb esetben mindkét kromatográfiás technikával megvalósított elválasztást $R_{S}$ értékeinek kisebb-nagyobb növekedése jellemezte $90 \quad v \%$ apoláros oldószertartalmú eluens alkalmazásáig.
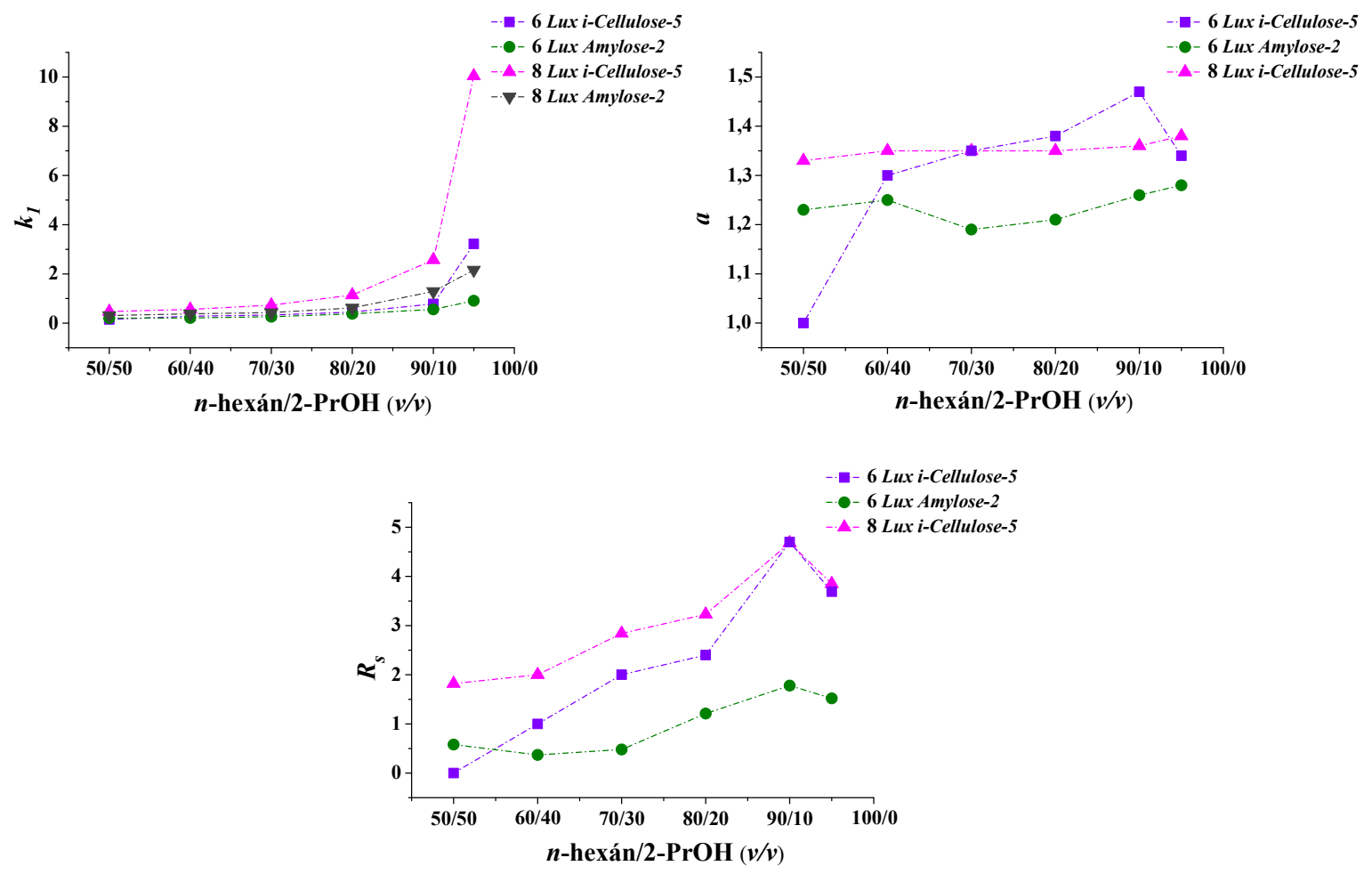

23. ábra A mozgófázis összetételének hatása a kromatográfiás paraméterekre Lux $i$ Cellulose-5 és Lux Amylose-2 kolonnán NP-LC körülmények között

Kromatográfiás körülmények: oszlopok, Lux Amylose-2 és Lux i-Cellulose-5; mozgófázis, $n$-hexán/2PrOH/DEA (50/50/0,1-95/5/0,1 v/v/v); áramlási sebesség, 1,0 $\mathrm{ml} \mathrm{perc}^{-1}$; detektálás, $210 \mathrm{~nm}$; hőmérséklet, $\mathrm{T}=25^{\circ} \mathrm{C}$. 

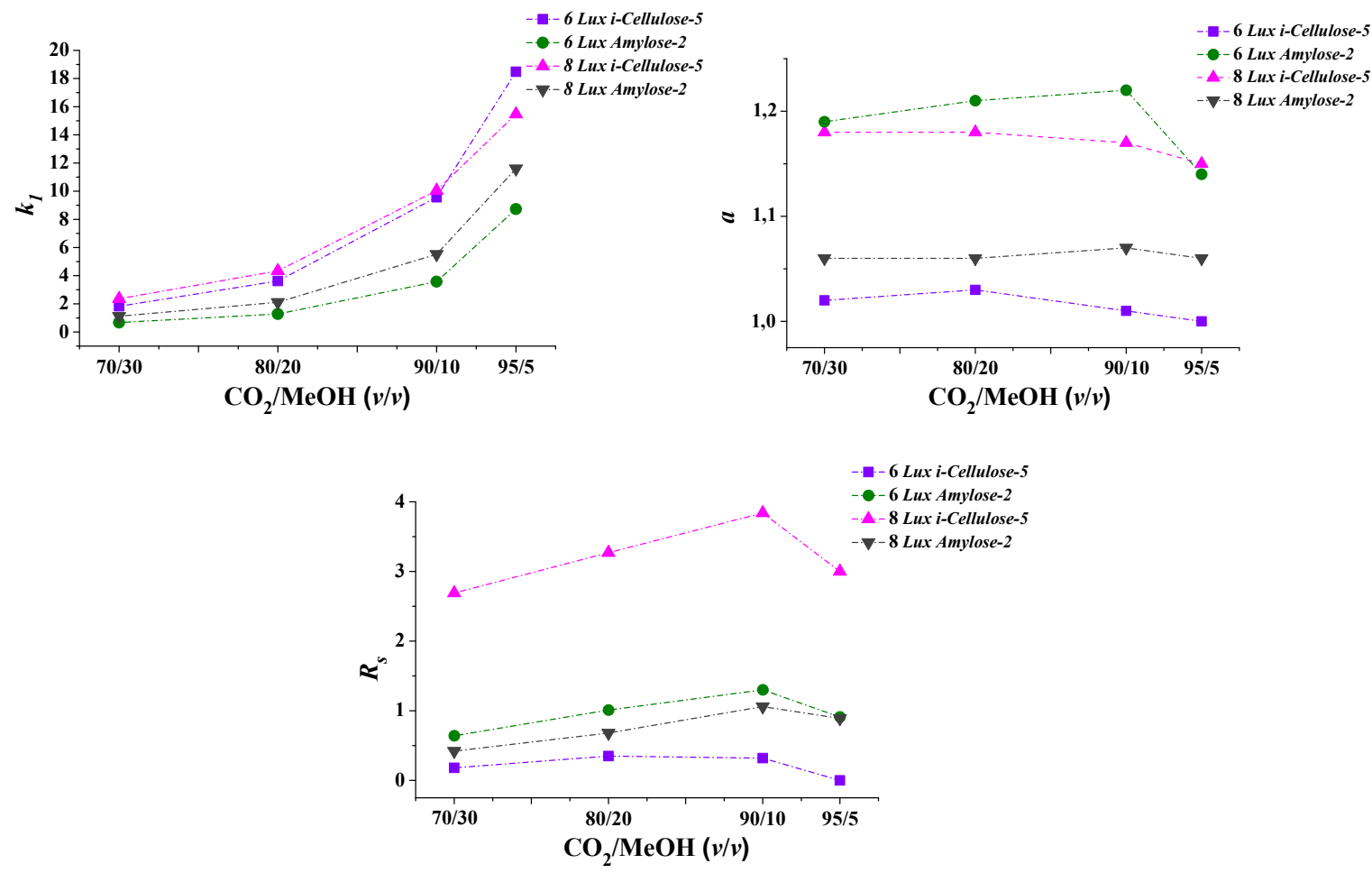

23. ábra (folytatás) A mozgófázis összetételének hatása a kromatográfiás paraméterekre Lux i-Cellulose-5 és Lux Amylose-2 kolonnán SFC módban

Kromatográfiás körülmények: oszlopok, Lux Amylose-2 és Lux i-Cellulose-5; mozgófázis, $\mathrm{CO}_{2} / \mathrm{MeOH}(70 / 30$ $95 / 5 v / v)$ és DEA (20 mM); áramlási sebesség, $2,0 \mathrm{ml}$ perc ${ }^{-1}$; detektálás, 210 és $260 \mathrm{~nm}$; hőmérséklet, $\mathrm{T}=40^{\circ} \mathrm{C}$; ellennyomás, 150 bar.

\subsubsection{A szerkezet és a retenció közötti összefüggések tanulmányozása}

A vizsgált limonén alapú biciklusos származékok közül az 5-7 vegyületek 1,3aminoalkohol, míg a 8 és 9 vegyületek 1,3,5- és 1,3,6-aminodiol származékok (13. ábra). Annak érdekében, hogy az elválasztani kívánt komponensek és az alkalmazott királis szelektorok szerkezetének a kromatográfiás viselkedésre gyakorolt hatásairól következtetéseket lehessen levonni, az öt vegyületet mind a hét cellulóz- és amilóz alapú állófázison tanulmányoztam, állandó összetételü mozgófázis alkalmazása mellett (8. és 9. táblázat). Az alkalmazott kromatográfiás körülményeket úgy választottam meg, hogy a vizsgált sztereoizomerek legalább részleges elválasztása megvalósítható legyen.

NP-LC módban méréseimet $n$-hexán/2-PrOH/DEA (50/50/0,1 v/v/v) összetételü eluenssel végeztem el. Néhány esetben az amilóz alapú kolonnákon ez az összetétel túl rövid retenciós időket eredményezett, ezért a megbízható összehasonlítás végett ilyen esetekben $n$-hexán/2-PrOH/DEA $(70 / 30 / 0,1 \quad v / v / v)$ összetételt választottam az analízishez. A 8 . táblázatban összefoglalt kromatográfiás adatok alapján megállapítható, hogy mindegyik poliszacharid alapú állófázison az 1,3,5- és 1,3,6-aminodiol vegyületek nagyobb retenciót 
mutattak az 1,3-aminoalkoholokkal szemben. Ettől eltérően viselkedett a $7\left(k_{1}=0,44\right)$ és 8 vegyület $\left(k_{1}=0,31\right)$ a Lux Cellulose-1 kolonnán. Az aminodiol vegyületeken (8 és 9) fellelhető „extra” hidroxilcsoport feltehetően hozzájárult ahhoz, hogy erősebb H-híd jöjjön létre a szelektorral, amely így nagyobb visszatartást (és egyben szelektivitást) eredményezett. A $N$ atomon fellelhető metilbenzil- és dibenzil funkciós csoportok jelenléte szintén jelentős mértékben befolyásolta a királis megkülönböztetést. A két benzilcsoporttal rendelkező vegyületek (7, 8 és 9) elválasztását nagyobb visszatartás, s egyben nagyobb enantioszelektivitás kísérte, mint a metilbenzil (5 és 6) származékokét. A megfigyelt kromatográfiás viselkedés a két benzilcsoporttal rendelkező vegyületek, illetve a szelektor között létrejövő $\pi-\pi$ kölcsönhatásoknak tulajdonítható.

Összehasonlítva a hét alkalmazott poliszacharid alapú kolonna hatékonyságát normál fázisú folyadákkromatográfiás körülmények között, a cellulóz trisz-(4-metilbenzoát) (Lux Cellulose-3), valamint a cellulóz trisz-(4-klór-3-metilfenilkarbamát) (Lux Cellulose-4) szelektor alkalmazása általában eredménytelennek bizonyult a limonén származékok enantioszelektív megkülönböztetésére. Továbbá, az 5 komponens csak amilóz trisz-(5-klór2-metilfenilkarbamát) alapú oszlopon (Lux Amylose-2) vált el. A 6-9 anyagok esetén a cellulóz trisz-(3-klór-4-metilfenilkarbamát) (Lux Cellulose-2), valamint a cellulóz trisz-(3,5diklórfenilkarbamát) (Lux i-Cellulose-5) szelektorok biztosították a hatékonyabb elválasztás lehetőségét (8. táblázat).

Az egyazon szelektorral bíró (3,5-dimetilfenilkarbamát) cellulóz és amilóz alapú állófázisokon megvalósított elválasztások eredményeit összevetve arra a következtetésre jutottam, hogy a vizsgált vegyületek Lux Cellulose-1 állófázison sok esetben nagyobb visszatartással eluálódtak, mint Lux Amylose-1 oszlopon. A metilbenzil csoportokkal rendelkező 6 vegyület elválasztásakor nagyobb enantioszelektivitást figyeltem meg Lux Amylose-1 állófázis alkalmazásával, míg a dibenzilszubsztituált aminoalkohol (7) és aminodiol (8 és 9) vegyületek esetén $\alpha$ értékei általában nagyobbak voltak a Lux Cellulose1 kolonnán, amint azt a 8 . táblázat adatai is mutatják. 
8. táblázat Limonénvázas biciklusos aminoalkoholok és aminodiolok kromatográfiás paraméterei $\left(k_{1}, \alpha, R_{S}\right)$, valamint az enantiomerek elúciós sorrendje NP-LC körülmények között poliszacharid alapú állófázisokon

\begin{tabular}{|c|c|c|c|c|c|}
\hline Vegyület & Oszlop & $k_{1}$ & $\alpha$ & $\boldsymbol{R}_{S}$ & $\begin{array}{c}\text { Elúciós } \\
\text { sorrend }\end{array}$ \\
\hline 5 & Amylose-2 & 0,19 & 1,26 & 0,44 & $B<A$ \\
\hline \multirow{3}{*}{6} & $i$-Cellulose-5 & 0,26 & 1,29 & 0,95 & $B<A$ \\
\hline & Amylose-1 & 0,17 & 1,29 & 0,95 & $B<A$ \\
\hline & Amylose-2* & 0,20 & 1,23 & 0,58 & $B<A$ \\
\hline \multirow{7}{*}{7} & Cellulose-1 & 0,44 & 1,63 & 1,92 & $A<B$ \\
\hline & Cellulose-2 & 0,11 & 2,70 & 1,82 & $A<B$ \\
\hline & Cellulose-3 & 0,14 & 1,00 & 0,00 & - \\
\hline & Cellulose-4 & 0,24 & 1,00 & 0,00 & - \\
\hline & $i$-Cellulose-5 & 0,30 & 1,77 & 3,00 & $A<B$ \\
\hline & Amylose-1 & 0,24 & 1,52 & 1,39 & $A<B$ \\
\hline & Amylose-2 & 0,29 & 1,00 & 0,00 & - \\
\hline \multirow{7}{*}{8} & Cellulose-1 & 0,31 & 2,53 & 5,11 & $A<B$ \\
\hline & Cellulose-2 & 0,38 & 1,91 & 2,82 & $B<A$ \\
\hline & Cellulose-3 & 0,15 & 1,60 & 0,70 & $B<A$ \\
\hline & Cellulose-4 & 0,49 & 1,00 & 0,00 & - \\
\hline & $i$-Cellulose-5 & 0,47 & 1,33 & 1,82 & $A<B$ \\
\hline & Amylose-1 & 0,44 & 1,25 & 1,65 & $B<A$ \\
\hline & Amylose-2 & 0,31 & 1,00 & 0,00 & - \\
\hline \multirow{7}{*}{9} & Cellulose-1 & 0,32 & 1,27 & 0,90 & $B<A$ \\
\hline & Cellulose-2 & 0,18 & 2,44 & 2,35 & $A<B$ \\
\hline & $i$-Cellulose-5 & 0,45 & 1,38 & 1,92 & $A<B$ \\
\hline & Amylose-1 & 0,44 & 1,84 & 0,95 & $A<B$ \\
\hline & Amylose-1* & 0,67 & 1,83 & 6,41 & $A<B$ \\
\hline & Amylose-2 & 0,38 & 2,05 & 2,45 & $B<A$ \\
\hline & Amylose-2* & 0,62 & 2,15 & 6,51 & $B<A$ \\
\hline
\end{tabular}

Kromatográfiás körülmények: oszlopok, Lux Cellulose-1, Cellulose-2, Cellulose-3, Cellulose-4, i-Cellulose-5, Amylose-1 és Amylose-2; mozgófázis, $n$-hexán/2-PrOH/DEA (50/50/0,1 $v / v / v)$, *n-hexán/2-PrOH/DEA $(70 / 30 / 0,1 v / v / v)$; áramlási sebesség, $1,0 \mathrm{ml}$ perc ${ }^{-1}$; detektálás, $230-260 \mathrm{~nm}$; hömérséklet, $\mathrm{T}=25^{\circ} \mathrm{C}$. 
Annak érdekében, hogy a két alkalmazott kromatográfiás technika teljesítőképességét is összehasonlíthassam az öt limonén alapú biciklusos aminoalkohol és aminodiol származék kromatográfiás vizsgálatán keresztül, a modellvegyületek elválasztását SFC technikával is vizsgáltam állandó összetételü $\left[\mathrm{CO}_{2} / \mathrm{MeOH}(80 / 20 v / v)\right.$ és DEA (20 mM)] mozgófázissal. A 8. és 9. táblázatban szereplő kromatográfiás adatok arra engednek következtetni, hogy a vizsgált molekulák közül az SFC alkalmazása az 5, 6 és 8, míg a NP-LC körülmények között a 7 és 9 vegyületek elválasztása során biztosított nagyobb enantioszelektivitást. Érdekes módon a felbontás értékei az esetek döntő többségében sokkal jobbak voltak, amikor az elválasztásokat SFC technikával hajtottam végre. Ennek valószínü oka a $\mathrm{CO}_{2}$ alapú mozgófázisok kisebb viszkozitása és az ebből eredő nagyobb kinetikai hatékonyság. A vegyületek szerkezete ebben az esetben is meghatározó szerepet töltött be a kromatográfiás jellemzők, úgymint a retenció és szelektivitás alakulásában. A 7 és 8 vegyületek kromatográfiás adatait összehasonlítva szembetűnő, hogy a hidroxilcsoportok jelenléte erős H-kötés kialakulásán keresztül járult hozzá a dibenzil-származékok nagyobb visszatartásához.

A 9. táblázatban szereplő adatok azt mutatják, hogy az elöbb említett vegyületek esetén a hétből csak három esetben kísérte a nagyobb $k_{l}$ értékeket nagyobb enantioszelektivitás, mely felhívja a figyelmet arra a tényre, hogy a fentebb említett H-kötés létrejötte nem feltétlen jár szelektívebb elválasztással. Hasonlóan a HPLC alapú normál fázisú elválasztások során tapasztaltakhoz, azon vegyületek esetén, melyek $N$ atomjához két benzilcsoport kapcsolódik (7-9 vegyületek), szelektívebb és hatékonyabb elválasztást értem el, mint a metilbenzil-származékok (5 és 6) esetén. Ez a megfigyelés alátámasztotta a $\pi-\pi$ kölcsönhatás királis felismerében betöltött fontos szerepét, melynek kialakulására sor kerülhet az állófázis és az elválasztandó komponensek között, függetlenül az alkalmazott szelektor (amilóz vagy cellulóz) vázától. Ami az állófázisok hatékonyságát illeti, SFC módban a legnagyobb enantioszelektivitást általában a Lux Amylose-1 és a Lux Cellulose-2 oszlopok nyújtották. Munkám során SFC módban is összehasonlítottam az azonos szelektorral (3,5-dimetilfenilkarbamát) rendelkező cellulóz- és amilóz alapú állófázisok teljesítőképességét. A vizsgált vegyületek visszatartása az esetek döntő többségében nagyobb volt Lux Cellulose-1 oszlopon, mint a Lux Amylose-1 állófázison, egyúttal az amilóz alapú oszloppal történő elválasztások a legtöbb esetben szelektívebbnek bizonyultak, mint a cellulóz trisz-(3,5-dimetilfenilkarbamát) szelektor esetén (9. táblázat). 
9. táblázat Limonénvázas biciklusos aminoalkoholok és aminodiolok kromatográfiás paraméterei $\left(k_{l}, \alpha, R_{S}\right)$, valamint az enantiomerek elúciós sorrendje SFC körülmények között poliszacharid alapú állófázisokon

\begin{tabular}{|c|c|c|c|c|c|}
\hline Vegyület & Oszlop & $k_{1}$ & $\alpha$ & $\boldsymbol{R}_{S}$ & $\begin{array}{l}\text { Elúciós } \\
\text { sorrend }\end{array}$ \\
\hline \multirow{7}{*}{5} & Cellulose-1 & 0,82 & 1,05 & 0,24 & $B<A$ \\
\hline & Cellulose-2 & 3,28 & 1,10 & 0,92 & $B<A$ \\
\hline & Cellulose-3 & 0,33 & 1,00 & 0,00 & - \\
\hline & Cellulose-4 & 3,31 & 1,14 & 1,50 & $B<A$ \\
\hline & $i$-Cellulose-5 & 3,76 & 1,00 & 0,00 & - \\
\hline & Amylose-1 & 0,51 & 1,49 & 2,18 & $B<A$ \\
\hline & Amylose-2 & 1,15 & 1,20 & 1,88 & $B<A$ \\
\hline \multirow{7}{*}{6} & Cellulose-1 & 0,77 & 1,07 & 0,36 & $B<A$ \\
\hline & Cellulose-2 & 3,34 & 1,31 & 3,15 & $B<A$ \\
\hline & Cellulose-3 & 0,28 & 1,00 & 0,00 & - \\
\hline & Cellulose-4 & 3,20 & 1,29 & 4,56 & $B<A$ \\
\hline & $i$-Cellulose-5 & 3,62 & 1,03 & 0,35 & $B<A$ \\
\hline & Amylose-1 & 0,55 & 1,00 & 0,00 & - \\
\hline & Amylose-2 & 1,28 & 1,21 & 1,01 & $B<A$ \\
\hline \multirow{7}{*}{7} & Cellulose-1 & 1,60 & 1,26 & 2,74 & $A<B$ \\
\hline & Cellulose-2 & 1,85 & 1,39 & 5,14 & $A<B$ \\
\hline & Cellulose-3 & 0,54 & 1,17 & 1,19 & $A<B$ \\
\hline & Cellulose-4 & 1,75 & 1,18 & 2,94 & $A<B$ \\
\hline & $i$-Cellulose-5 & 2,17 & 1,24 & 3,51 & $A<B$ \\
\hline & Amylose-1 & 1,29 & 1,40 & 5,39 & $B<A$ \\
\hline & Amylose-2 & 1,33 & 1,04 & 0,49 & $B<A$ \\
\hline \multirow{7}{*}{8} & Cellulose-1 & 2,46 & 1,54 & 5,85 & $A<B$ \\
\hline & Cellulose-2 & 5,35 & 1,10 & 1,65 & $A<B$ \\
\hline & Cellulose-3 & 1,05 & 1,06 & 0,57 & $A<B$ \\
\hline & Cellulose-4 & 4,33 & 1,09 & 1,64 & $A<B$ \\
\hline & $i$-Cellulose-5 & 4,34 & 1,18 & 3,27 & $A<B$ \\
\hline & Amylose-1 & 2,17 & 3,44 & 19,10 & $B<A$ \\
\hline & Amylose-2 & 2,11 & 1,06 & 0,68 & $B<A$ \\
\hline
\end{tabular}

Kromatográfiás körülmények: oszlopok, Lux Cellulose-1, Cellulose-2, Cellulose-3, Cellulose-4, i-Cellulose-5, Amylose-1 és Amylose-2; mozgófázis, $\mathrm{CO}_{2} / \mathrm{MeOH}(80 / 20 \mathrm{v} / \mathrm{v})$ és $20 \mathrm{mM}$ DEA; áramlási sebesség, 2,0 $\mathrm{ml}^{2}$ perc $^{-}$ 1; detektálás, $210-230 \mathrm{~nm}$; ellennyomás, 150 bar; hőmérséklet, $\mathrm{T}=40{ }^{\circ} \mathrm{C}$. 
9. táblázat (folytatás) Limonénvázas biciklusos aminoalkoholok és aminodiolok kromatográfiás paraméterei $\left(k_{l}, \alpha, R_{S}\right)$, valamint az enantiomerek elúciós sorrendje SFC körülmények között poliszacharid alapú állófázisokon

\begin{tabular}{cccccc}
\hline Vegyület & Oszlop & $\boldsymbol{k}_{\boldsymbol{1}}$ & $\alpha$ & $\boldsymbol{R}_{\boldsymbol{S}}$ & $\begin{array}{c}\text { Elúciós } \\
\text { sorrend }\end{array}$ \\
\hline \multirow{5}{*}{9} & Cellulose-1 & 2,36 & 1,04 & 0,46 & $A<B$ \\
& Cellulose-2 & 3,49 & 1,44 & 6,05 & $A<B$ \\
& Cellulose-3 & 0,76 & 1,00 & 0,00 & - \\
& Cellulose-4 & 3,11 & 1,41 & 6,26 & $A<B$ \\
& $i$-Cellulose-5 & 4,35 & 1,06 & 1,07 & $A<B$ \\
& Amylose-1 & 4,16 & 1,22 & 3,41 & $B<A$ \\
& Amylose-2 & 2,27 & 1,08 & 0,84 & $B<A$ \\
\hline
\end{tabular}

Kromatográfiás körülmények: oszlopok, Lux Cellulose-1, Cellulose-2, Cellulose-3, Cellulose-4, i-Cellulose-5, Amylose-1 és Amylose-2; mozgófázis, $\mathrm{CO}_{2} / \mathrm{MeOH}(80 / 20$ v/v) és $20 \mathrm{mM}$ DEA; áramlási sebesség, 2,0 $\mathrm{ml}$ perc ${ }^{1}$; detektálás, $210-230 \mathrm{~nm}$; ellennyomás, 150 bar; hömérséklet, $\mathrm{T}=40^{\circ} \mathrm{C}$.

Összefoglalva tehát a szerkezet-retenció összefüggésekkel kapcsolatos eredményeket, a két kromatográfiás technika közül az esetek többségében SFC technikával jobb és hatékonyabb elválasztásokat értem el. Minden aminoalkohol és aminodiol származék esetén az alapvonalra történő elválasztás megvalósítható volt, bár különböző állófázisok segítségével. Ebből következik, hogy a hét alkalmazott, kereskedelmi forgalomban is elérhető poliszacharid alapú királis állófázis egymást kiegészítve nyújtanak a limonén alapú biciklusos aminoalkohol- és aminodiol vegyületek számára hatékony enantioszelektív elválasztást.

Az elúció sorrendjét természetesen a poliszacharid alapú állófázisokkal történő elválasztások során is minden esetben meghatároztam (8. és 9. táblázat). HPLC méréseim során NP módban az elúciós sorrend változása az alábbiak szerint alakult: az 5 és $\mathbf{6}$ molekulák esetén $B<A$, a 7 enantiomer pár esetén $A<B$ míg a 8 vegyület esetén $L u x$ Cellulose-1 és Lux i-Cellulose-5 oszlopon $A<B$, míg Lux Cellulose-2, Lux Cellulose-3 és Lux Amylose-1 oszlopokon $B<A$ volt. A 9 anyag esetén a Lux Cellulose-1 és Lux Amylose2 oszlopon az elúciós sorrend megegyezett $(B<A)$, míg Lux Cellulose-2, Lux i-Cellulose-5 és Lux Amylose-1 oszlopokon történő elválasztásokat fordított elúciós sorrend $(A<B)$ jellemzett. Az SFC-vel végrehajtott analízisek során néhány igen érdekes és jellegzetes különbséget figyeltem meg az enantiomerek eluálódási sorrendjét illetően. Az 5 és 6 anyagok azonos sorrendben eluálódtak $(B<A)$, függetlenül az alkalmazott oszloptól (és kromatográfiás technikától). A 7, 8 és 9 vegyületek esetén az elúció sorrendje ellentétesen alakult a cellulóz- és amilóz alapú kolonnákon. A cellulóz alapú állófázisokon $A<B$, míg 
az amilóz alapú oszlopokon $B<A$ sorrend jellemezte az elválasztásokat. Ez a megfigyelés rávilágít arra, hogy míg NP-LC módban mind a poliszacharid váza, mind pedig a szelektor szerkezete, addig SFC körülményeket alkalmazva csak maga a poliszacharid váz gyakorolt jelentős hatást az enantiomerek elúciós sorrendjére. Fontosnak tartom kiemelni, hogy poliszacharid alapú állófázisok alkalmazásakor az elúciós sorrend alakulásában általános szabályszerűség nem volt megfigyelhető, mely ráirányítja a figyelmet minden enantiomer és/vagy diasztereomer egyéni azonosításának szükségességére. Vizsgálataim során számos esetben arra is fény derült, hogy az enantiomerek elúciós sorrendje a különféle állófázisok alkalmazása mellett megfordulhat az alkalmazott kromatográfiás technika (NP-LC vagy SFC) függvényében. Ez különösen az amilóz alapú szelektorokon történő elválasztásokra volt jellemző, ahol a különböző összetételü eluensek használata eltérő konformációs változásokat idézhet elő a királis szelektor ,üregeiben”, ezáltal még hangsúlyosabb szerepet adva a sztérikus hatásoknak a királis felismerésben [68].

\subsubsection{A hőmérséklet hatása és termodinamikai paraméterek}

A biciklusos aminoalkohol és aminodiol vegyületek kromatográfiás vizsgálatának következő lépéseként a termodinamikai viselkedés jellemzőinek feltérképezését tüztem ki célul. Az öt limonén vázzal rendelkező vegyület enantioszelektív elválasztását Lux Amylose1 és Lux Cellulose-1 kolonnákon hajtottam végre mindkét kromatográfiás módszerrel 10-50 ${ }^{\circ} \mathrm{C}$ hőmérséklettartományban. NP-LC módban a következő eluensösszetételeket alkalmaztam: az 5 és 6 anyagok elválasztásakor $n$-hexán/2-PrOH/DEA (90/10/0,1 v/v/v) Lux Cellulose-1 és Lux Amylose-1 oszlopokon, a 7 és 9 anyagoknál $n$-hexán/2-PrOH/DEA (70/30/0,1 v/v/v) Lux Cellulose-1 kolonnán, valamint $n$-hexán/2-PrOH/DEA (50/50/0,1 $v / v / v)$ a Lux Amylose-2 kolonnán. SFC méréseim során $\mathrm{CO}_{2} / \mathrm{MeOH}(80 / 20 v / v)$ elegyét használtam, amely $20 \mathrm{mM}$ DEA adalékot tartalmazott (10. és 11. táblázat). A poliszacharid alapú állófázisokon $k_{l}$, valamint $\alpha$ értékei csökkentek a hőmérséklet emelésével, viszont néhány esetben ettől eltérő viselkedést tapasztaltam. Lux Amylose-1 kolonnán a 6 vegyület SFC módszerrel való elválasztásakor, valamint az 5 anyag mind NP-LC, mind SFC módszerrel történő analízise során a csökkenő visszatartást növekvő szelektivitás kísérte. Ami a felbontást illeti, $R_{S}$ értékei sok esetben csökkentek a hőmérséklet emelkedésével mindkét kromatográfiás módszer alkalmazásakor. Lux Amylose-1 oszlopon NP-LC módban az 5 vegyületet leszámítva minden esetben romlott az elválasztás hatékonysága, míg SFC 
körülmények között a felbontás értékei sok esetben határozott növekedést mutattak az oszlop hőmérsékletének növelésével (jelezve az oszlop kinetikai hatékonyságának növekedését).

10. táblázat Különböző hőmérsékleten mért kromatográfiás paraméterek $\left(k_{1}, \alpha, R_{S}\right)$ értékei NP-LC módszer alkalmazása során Lux Cellulose-1 és Lux Amylose-1 oszlopokon

\begin{tabular}{|c|c|c|c|c|c|c|}
\hline \multirow{2}{*}{ Vegyület } & \multirow{2}{*}{$k_{l}, \alpha, R_{S}$} & \multicolumn{5}{|c|}{ Hőmérséklet $\left({ }^{\circ} \mathrm{C}\right)$} \\
\hline & & 10 & 20 & 30 & 40 & 45 \\
\hline \multicolumn{7}{|c|}{ Lux Cellulose-1 } \\
\hline \multirow{3}{*}{5} & $k_{1}$ & 1,06 & 0,87 & 0,71 & 0,60 & 0,55 \\
\hline & $\alpha$ & 1,00 & 1,00 & 1,00 & 1,00 & 1,00 \\
\hline & $R_{S}$ & 0,00 & 0,00 & 0,00 & 0,00 & 0,00 \\
\hline \multirow{3}{*}{6} & $k_{1}$ & 1,04 & 0,88 & 0,74 & 0,62 & 0,59 \\
\hline & $\alpha$ & 1,19 & 1,13 & 1,07 & 1,00 & 1,00 \\
\hline & $R_{S}$ & 1,03 & 1,15 & 0,55 & 0,00 & 0,00 \\
\hline \multirow{3}{*}{7} & $k_{1}$ & 0,83 & 0,65 & 0,51 & 0,39 & 0,34 \\
\hline & $\alpha$ & 1,63 & 1,60 & 1,57 & 1,54 & 1,53 \\
\hline & $R_{S}$ & 3,24 & 3,06 & 2,59 & 1,71 & 1,33 \\
\hline \multirow{3}{*}{8} & $k_{1}$ & 0,61 & 0,54 & 0,49 & 0,43 & 0,40 \\
\hline & $\alpha$ & 2,76 & 2,65 & 2,53 & 2,41 & 2,33 \\
\hline & $R_{S}$ & 5,49 & 4,62 & 5,46 & 5,00 & 3,82 \\
\hline \multirow{3}{*}{9} & $k_{1}$ & 0,67 & 0,59 & 0,54 & 0,52 & 0,48 \\
\hline & $\alpha$ & 1,40 & 1,27 & 1,14 & 1,00 & 1,00 \\
\hline & $R_{S}$ & 1,61 & 1,17 & 0,96 & 0,00 & 0,00 \\
\hline \multicolumn{7}{|c|}{ Lux Amylose-1 } \\
\hline \multirow{3}{*}{5} & $k_{1}$ & 0,88 & 0,74 & 0,63 & 0,55 & 0,50 \\
\hline & $\alpha$ & 1,00 & 1,05 & 1,09 & 1,13 & 1,40 \\
\hline & $R_{S}$ & 0,00 & 0,58 & 0,95 & 1,00 & 0,76 \\
\hline \multirow{3}{*}{6} & $k_{1}$ & 0,74 & 0,65 & 0,57 & 0,51 & 0,47 \\
\hline & $\alpha$ & 1,23 & 1,22 & 1,21 & 1,20 & 1,20 \\
\hline & $R_{S}$ & 2,00 & 1,90 & 1,79 & 1,56 & 1,03 \\
\hline \multirow{3}{*}{7} & $k_{1}$ & 0,19 & 0,14 & 0,11 & 0,08 & 0,07 \\
\hline & $\alpha$ & 1,00 & 1,00 & 1,00 & 1,00 & 1,00 \\
\hline & $R_{S}$ & 0,00 & 0,00 & 0,00 & 0,00 & 0,00 \\
\hline \multirow{3}{*}{8} & $k_{1}$ & 0,40 & 0,34 & 0,28 & 0,23 & 0,20 \\
\hline & $\alpha$ & 1,12 & 1,11 & 1,09 & 1,08 & 1,07 \\
\hline & $R_{S}$ & $<0,2$ & $<0,2$ & $<0,2$ & $<0,2$ & $<0,2$ \\
\hline \multirow{3}{*}{9} & $k_{1}$ & 0,37 & 0,31 & 0,25 & 0,21 & 0,19 \\
\hline & $\alpha$ & 1,24 & 1,23 & 1,22 & 1,21 & 1,20 \\
\hline & $R_{S}$ & 0,76 & 1,04 & 0,87 & 0,70 & 0,46 \\
\hline
\end{tabular}

Kromatográfiás körülmények: oszlopok, Lux Cellulose-1 és Lux Amylose-1; mozgófázis Lux Cellulose-1 és Lux Amylose-1 oszlopokon 5 és 6 vegyületek esetén, $n$-hexán/2-PrOH/DEA (90/10/0,1 v/v/v), Lux Cellulose-1 oszlopon 7-9 vegyületek esetén, $n$-hexán/2-PrOH/DEA (70/30/0,1 v/v/v) és Lux Amylose-1 oszlopon, $n$ hexán/2-PrOH/DEA 50/50/0,1 v/v/v); áramlási sebesség, 1,0 ml perc ${ }^{-1}$; detektálás, 220-240 nm. 
11. táblázat Különböző hőmérsékleten mért kromatográfiás paraméterek $\left(k_{1}, \alpha, R_{S}\right)$ értékei SFC módszer alkalmazása során Lux Cellulose-1 és Lux Amylose-1 oszlopokon

\begin{tabular}{|c|c|c|c|c|c|}
\hline \multirow{2}{*}{ Vegyület } & \multirow{2}{*}{$\begin{array}{c}\boldsymbol{k}_{l}, \\
\alpha \\
\boldsymbol{R}_{S}\end{array}$} & \multicolumn{4}{|c|}{ Hőmérséklet ( $\left.{ }^{\circ} \mathrm{C}\right)$} \\
\hline & & $20{ }^{\circ} \mathrm{C}$ & $30{ }^{\circ} \mathrm{C}$ & $40^{\circ} \mathrm{C}$ & $50^{\circ} \mathrm{C}$ \\
\hline \multicolumn{6}{|c|}{ Lux Cellulose-1 } \\
\hline \multirow{3}{*}{5} & $\boldsymbol{k}_{1}$ & 0,70 & 0,71 & 0,73 & 0,78 \\
\hline & $\alpha$ & 1,07 & 1,06 & 1,05 & 1,04 \\
\hline & $\boldsymbol{R}_{S}$ & 0,59 & 0,50 & 0,45 & 0,42 \\
\hline \multirow{3}{*}{6} & $k_{1}$ & 0,65 & 0,66 & 0,69 & 0,73 \\
\hline & $\alpha$ & 1,09 & 1,08 & 1,06 & 1,04 \\
\hline & $\boldsymbol{R}_{S}$ & 0,64 & 0,46 & 0,40 & 0,32 \\
\hline \multirow{3}{*}{7} & $k 1$ & 1,63 & 1,48 & 1,39 & 1,36 \\
\hline & $\alpha$ & 1,34 & 1,29 & 1,26 & 1,22 \\
\hline & $\boldsymbol{R}_{S}$ & 4,41 & 3,79 & 3,35 & 2,80 \\
\hline \multirow{3}{*}{8} & $k_{1}$ & 2,35 & 2,23 & 2,20 & 2,27 \\
\hline & $\alpha$ & 1,69 & 1,62 & 1,53 & 1,45 \\
\hline & $\boldsymbol{R}_{S}$ & 8,50 & 8,22 & 7,47 & 6,49 \\
\hline \multirow{3}{*}{9} & $k_{1}$ & 2,29 & 2,15 & 2,10 & 2,16 \\
\hline & $\alpha$ & 1,08 & 1,05 & 1,03 & 1,00 \\
\hline & $\boldsymbol{R}_{S}$ & 1,01 & 0,76 & 0,42 & 0,00 \\
\hline \multicolumn{6}{|c|}{ Lux Amylose-1 } \\
\hline \multirow{3}{*}{5} & $k_{1}$ & 0,37 & 0,31 & 0,30 & 0,35 \\
\hline & $\alpha$ & 1,58 & 1,68 & 1,75 & 1,84 \\
\hline & $\boldsymbol{R}_{S}$ & 1,65 & 2,11 & 2,34 & 2,46 \\
\hline \multirow{3}{*}{6} & $k_{1}$ & 0,45 & 0,35 & 0,33 & 0,37 \\
\hline & $\alpha$ & 1,00 & 1,05 & 1,11 & 1,16 \\
\hline & $R_{S}$ & 0,00 & 0,21 & 0,51 & 0,65 \\
\hline \multirow{3}{*}{7} & $k 1$ & 1,29 & 1,04 & 0,92 & 0,90 \\
\hline & $\alpha$ & 1,61 & 1,53 & 1,41 & 1,31 \\
\hline & $\boldsymbol{R}_{S}$ & 6,50 & 5,92 & 5,23 & 3,33 \\
\hline \multirow{3}{*}{8} & $k_{1}$ & 2,48 & 2,18 & 2,05 & 2,14 \\
\hline & $\alpha$ & 4,45 & 3,92 & 3,31 & 2.78 \\
\hline & $\boldsymbol{R}_{S}$ & 14,63 & 18,70 & 18,87 & 17.87 \\
\hline \multirow{3}{*}{9} & $k_{1}$ & 3,77 & 3,48 & 3,35 & 3.34 \\
\hline & $\alpha$ & 1,30 & 1,26 & 1,21 & 1.17 \\
\hline & $\boldsymbol{R}_{S}$ & 3,34 & 3,78 & 3,33 & 1,95 \\
\hline
\end{tabular}

Kromatográfiás körülmények: oszlopok, Lux Cellulose-1 és Lux Amylose-1; mozgófázis, $\mathrm{CO}_{2} / \mathrm{MeOH}(80 / 20 \mathrm{v} / \mathrm{v})$ és $20 \mathrm{mM}$ DEA; áramlási sebesség, $2,0 \mathrm{ml}^{\text {perc }}{ }^{-1}$; detektálás, $210-230 \mathrm{~nm}$; ellennyomás, 150 bar. 
A 12. táblázatban a van't Hoff egyenlet alapján kiszámolt termodinamikai jellemzőket foglaltam össze. Amint azt a termodinamika adatok mutatják, $\Delta\left(\Delta H^{\circ}\right)$ értékei NP-LC módban -8,2 és $+2,9$ kJ mol ${ }^{-1}$ között, míg SFC módban végzett elválasztások során 12,4 és $+4,0 \mathrm{~kJ} \mathrm{~mol}^{-1}$ értéktartományban változtak. A legnegatívabb $\Delta\left(\Delta H^{\circ}\right)$ értékek megmutatták, hogy az elválasztandó vegyület mozgófázisból az állófázisba történő átjutása exoterm folyamat. A két kromatográfiás technikát összehasonlítva általánosan megállapítható, hogy Lux Cellulose-1 oszlopon $\Delta\left(\Delta H^{\circ}\right)$ negatívabb volt a HPLC elválasztások során, mint SFC módban. Ezzel ellentétben a Lux Amylose-1 állófázis esetén sok esetben SFC körülményeket alkalmazva negatívabb $\Delta\left(\Delta H^{\circ}\right)$ értékeket kaptam, mint NPLC elválasztások során.

A 8 vegyület és a Lux Amylose-1 oszlop szelektora [amilóz (trisz-(3,5dimetilfenilkarbamát)] közötti kölcsönhatásokat a legnegatívabb $\Delta\left(\Delta H^{\circ}\right)$ és $\Delta\left(\Delta S^{\circ}\right)$ értékek jelzik. Hasonlóan a makrociklusos glikopeptid- és ikerionos ioncserélő típusú oszlopokon történő elválasztások során tapasztaltakhoz, ezen állófázis típusnál is amennyiben $\Delta\left(\Delta H^{\circ}\right)$ negatív volt, $\Delta\left(\Delta S^{\circ}\right)$ szintén negatívnak adódott, és természetesen a pozitív $\Delta\left(\Delta H^{\circ}\right)$ értékeket pozitív $\Delta\left(\Delta S^{\circ}\right)$ kísérte. Abban az esetben, amikor $\Delta\left(\Delta H^{\circ}\right)$ és $\Delta\left(\Delta S^{\circ}\right)$ is pozitív volt, a szelektivitás nőtt a hőmérséklet emelésével. Ilyen kromatográfiás viselkedésre példa az $\mathbf{5}$ vegyület esete Lux Amylose-1 kolonnán mindkét kromatográfiás technika alkalmazása során, illetve a 6 vegyület ugyanezen állófázison SFC módban. Ezekben az esetekben a hőmérséklet emelkedésével $\Delta\left(\Delta H^{\circ}\right)$ változása kedvező hatással bírt az enantioszelektivitásra. A megfigyelt, termodinamikai oldalról rendhagyónak számító kromatográfiás viselkedés során az entalpiatagot meghaladó entrópiatag hozzájárulása biztosította a negatív $\Delta\left(\Delta G^{\circ}\right)$ értékeit, így a folyamat entrópiavezéreltnek tekinthető.

Amint azt a 12. táblázat mutatja, mindkét kromatográfiás technikával történő elválasztást döntően entalpiavezérelt folyamatok kísérték $(Q>1)$. A két 3,5dimetilfenilkarbamát szelektorral rendelkező amilóz és cellulóz alapú állófázison ( $L u x$ Amylose-1 és Lux Cellulose-1) végrehajtott elválasztások alapján kijelenthető, hogy néhány kivétellel (a 6 komponens a Lux Amylose-1, illetve 8 és 9 anyagok a Lux Cellulose-1 oszlopon) SFC alkalmazásával hatékonyabb volt a limonén alapú biciklusos aminolakohol és aminodiol vegyületek királis felismerése, melyet a $\Delta\left(\Delta G^{\circ}\right)_{298 K}$ negatívabb értékei bizonyítanak. A limonén alapú biciklusos aminoalkohol és aminodiol vegyületek módosított poliszacharid alapú oszlopokkal kapott jellemző enantioszelektív elválasztására a Függelékben mutatok be néhány példát. 
12. táblázat Termodinamikai paraméterek, $\Delta\left(\Delta H^{\circ}\right), \Delta\left(\Delta S^{\circ}\right), \quad T x \Delta\left(\Delta S^{\circ}\right)_{298 K}, \Delta\left(\Delta G^{o}\right)$, korrelációs koefficiens $\left(R^{2}\right)$ és $Q$ értékei Lux Cellulose-1 és Lux Amylose-1 oszlopokon

\begin{tabular}{|c|c|c|c|c|c|c|c|}
\hline Vegyület & Módszer & $\begin{array}{l}-\Delta\left(\Delta \mathbf{H}^{0}\right) \\
(\mathbf{k J} / \mathbf{m o l})\end{array}$ & $\begin{array}{c}-\Delta\left(\Delta \mathbf{S}^{\mathbf{0}}\right) \\
(\mathbf{J} /(\mathbf{m o l} * \mathbf{K})\end{array}$ & $\begin{array}{c}\text { Korrelációs } \\
\text { koefficiens } \\
\left(R^{2}\right) \\
\end{array}$ & $\begin{array}{c}-\mathrm{Tx} \Delta\left(\Delta \mathbf{S}^{0}\right)_{298 \mathrm{~K}} \\
\quad(\mathrm{~kJ} / \mathrm{mol})\end{array}$ & $\begin{array}{c}-\Delta\left(\Delta \mathbf{G}^{0}\right)_{298 \mathrm{~K}} \\
\quad(\mathbf{k J} / \mathbf{m o l})\end{array}$ & $Q$ \\
\hline \multicolumn{8}{|c|}{ Lux Cellulose-1 } \\
\hline \multirow[t]{2}{*}{5} & NP-LC & - & - & - & - & - & - \\
\hline & SFC & 0,9 & 2,6 & 0,992 & 0,8 & 0,1 & 1,1 \\
\hline \multirow[t]{2}{*}{6} & NP-LC & 4,3 & 13,7 & 0,990 & 4,1 & 0,2 & 1,1 \\
\hline & SFC & 1,2 & 3,4 & 0,991 & 1,0 & 0,2 & 1,2 \\
\hline \multirow[t]{2}{*}{7} & NP-LC & 4,3 & 13,7 & 0,990 & 4,1 & 0,2 & 1,1 \\
\hline & SFC & 2,5 & 6,1 & 0,999 & 1,8 & 0,7 & 1,4 \\
\hline \multirow[t]{2}{*}{8} & NP-LC & 3,6 & 4,2 & 0,991 & 1,3 & 2,3 & 2,8 \\
\hline & SFC & 4,0 & 9,3 & 0,993 & 2,8 & 1,2 & 1,4 \\
\hline \multirow[t]{2}{*}{9} & NP-LC & 8,2 & 26,0 & 0,991 & 7,7 & 0,5 & 1,1 \\
\hline & SFC & 2,0 & 6,2 & 0,991 & 1,8 & 0,2 & 1,1 \\
\hline \multicolumn{8}{|c|}{ Lux Amylose-1 } \\
\hline \multirow[t]{2}{*}{5} & NP-LC & $-2,9$ & $-10,1$ & 0,992 & $-3,0$ & 0,1 & 0,9 \\
\hline & SFC & $-3,8$ & $-16,8$ & 0,996 & $-5,0$ & 1,2 & 0,8 \\
\hline \multirow[t]{2}{*}{6} & NP-LC & 0,6 & 0,4 & 0,993 & 0,1 & 0,5 & 6,0 \\
\hline & SFC & $-4,0$ & $-13,6$ & 0,998 & $-4,1$ & 0,1 & 0,9 \\
\hline \multirow[t]{2}{*}{7} & NP-LC & - & - & - & - & - & - \\
\hline & SFC & 5,5 & 14,7 & 0,990 & 4,4 & 1,1 & 1,3 \\
\hline \multirow[t]{2}{*}{8} & NP-LC & 1,1 & 2,8 & 0,998 & 0,8 & 0,3 & 1,4 \\
\hline & SFC & 12,4 & 29,8 & 0,990 & 8,9 & 3,5 & 1,4 \\
\hline \multirow[t]{2}{*}{9} & NP-LC & 0,8 & 1,0 & 0,994 & 0,3 & 0,5 & 2,7 \\
\hline & SFC & 2,9 & 7,6 & 0,994 & 2,3 & 0,6 & 1,3 \\
\hline
\end{tabular}

Kromatográfiás körülmények: oszlopok, Lux Cellulose-1 és Lux Amylose-1; mozgófázis, NP-LC módban, 5 és 6 vegyületek esetén Lux-Cellulose-1 és Lux Amylose-1 oszlopokon, $n$-hexán/2-PrOH/DEA (90/10/0,1 v/v/v), 7-9 vegyületek esetén Lux Cellulose-1 oszlopon, $n$-hexán/2-PrOH/DEA (70/30/0,1 v/v/v) és Lux Amylose-2 oszlopon, $n$-hexán/2-PrOH/DEA (50/50/0,1 v/v/v), SFC körülmények között az összes poliszacharid alapú oszlopon, $\mathrm{CO}_{2} / \mathrm{MeOH} 80 / 20(v / v)$ és $20 \mathrm{mM}$ DEA; áramlási sebesség, NP-LC módban, 1,0 ml perc ${ }^{-1}$ és $\mathrm{SFC}$ körülmények között, 2,0 ml perc ${ }^{-1}$; detektálás, 220-240 nm; $R^{2}$, ln $\alpha$ és 1/T függvények korrelációs koefficiense; $Q=\Delta\left(\Delta H^{9}\right) / \operatorname{Tx} \Delta(\Delta S)_{298}$, hömérséklettartomány, $\mathrm{T}=10-50{ }^{\circ} \mathrm{C}$. 


\section{6. Összefoglalás}

Célkitüzésemnek megfelelően sikeresen megvalósítottam gyógyszerkémiai jelentőséggel rendelkező királis vegyületek, nevezetesen limonénvázas karbociklusos $\beta$ aminosavak, $N$-szubsztituált ciklusos $\beta$-aminosavak, illetve limonén alapú aminoalkoholok és aminodiolok királis állófázisok alkalmazásán alapuló enantioszelektív kromatográfiás vizsgálatát. Munkám során tanulmányoztam az enantiomerek megkülönböztetési folyamatát, valamint az alkalmazott kromatográfiás körülmények elválasztásra gyakorolt hatását.

\section{A limonénvázas karbociklusos $\beta$-aminosavak elválasztását fordított fázisú} körülmények között és poláris-ionos módban tanulmányoztam makrociklusos glikopeptid alapú szelektorokkal rendelkező Chirobiotic ${ }^{T M} T, T A G$ és $R$ állófázisokon.

A mozgófázis alkotóinak elválasztásra gyakorolt hatásának tanulmányozásával megállapítottam, hogy a vízben gazdagabb eluens alkalmazásakor megfigyelt növekvő visszatartás a szelektor „kosarában” kialakuló hidrofób kölcsönhatásoknak köszönhető. A nagyobb $\mathrm{MeOH}$ tartalmú mozgófázis alkalmazását kísérő növekedő retenció oka az ionos és dipólusos kölcsönhatások kialakulásában keresendő. Vizsgálataim rámutattak, hogy az alkalmazott alkohol módosítók közül $\mathrm{MeOH}$, valamint 1-PrOH alkalmazása biztosította a karbociklusos $\beta$-aminosavak leghatékonyabb elválasztását.

Elsőként igazoltam a sztöchiometrikus helyettesítési modell alkalmazásával, hogy makrociklusos glikopeptid alapú állófázisok esetén az ionos kölcsönhatási folyamatok is jelentős szerepet tölthetnek be az elválasztás mechanizmusában. A meghatározott $\lg k_{1} v s$. $\lg c_{\text {ellenion }}$ egyenesek meredeksége alapján megállapítottam, hogy a teikoplanin aglikon alapú szelektor az ikerionos állófázisokhoz közelebb álló viselkedést mutat karbociklusos $\beta$ aminosavak elválasztása során.

A cukoregységek elválasztásban betöltött szerepének tanulmányozása során a kiszámolt $\Delta\left(\Delta G^{\circ}\right)_{T A G}-\Delta\left(\Delta G^{\circ}\right)_{T}$ különbségek megmutatták, hogy teikoplanin alapú szelektor alkalmazása révén a szelektoron fellelhető szénhidrátegységek sztérikus gátláson keresztül kedvezőtlenül befolyásolták a királis felismerést. Összehasonlítva az alkalmazott glikopeptid alapú állófázisok elválasztóképességét megállapítottam, hogy a vizsgált vegyületek elválasztása az esetek döntő többségében a teikoplanin aglikon alapú oszlopon bizonyult hatékonyabbnak. 
Az elválasztás hömérsékletfüggésének vizsgálata során a legtöbbször tapasztalt, úgynevezett termodinamikai hatástól eltérő kromatográfiás viselkedést figyeltem meg: a hőmérséklet emelésével csökkenő retenciót nagyobb enantioszelektivitás kísérte, illetve sok esetben a felbontás is javult. A van't Hoff-egyenlet kromatográfiában használt általános alakját alkalmazva termodinamikai jellemzők meghatározásán keresztül megállapítottam, hogy a legtöbb enantiomerpár királis megkülönböztetése entrópia által vezérelt folyamat, de megfigyeltem entalpiavezérelt elválasztást is.

Megállapítottam, hogy makrociklusos glikopeptid alapú állófázisok alkalmazása során a limonénvázas karbociklusos $\beta$-aminosavak szerkezetében fellelhető karboxil-, amino- és 2-propil funkciós csoportokhoz kapcsolódó szénatomok eltérő konfigurációja nem befolyásolta az elúciós sorrend alakulását.

\section{Az $N$-metilszubsztituált és amidált ciklusos $\beta$-aminosavak folyadékkromatográfiás elválasztását ikerionos állófázisokon (Chiralpak ${ }^{\circledR} Z W I X(+)$ és $\left.Z W I X(-)\right)$ végeztem el poláris-ionos módban.}

Az eluensösszetétel változtatásának elválasztásra gyakorolt hatása vizsgálatával rámutattam, hogy az aprotikus karakterü $\mathrm{MeCN}$ térfogatarányának növelésével a retenciós tényező szinte minden esetben nőtt. A megfigyelt kromatográfiás viselkedés az ionos vagy ionizálható komponensek csökkent szolvatáltságával és ezáltal az alkalmazott szelektorral való erősebb elektrosztatikus kölcsönhatások kialakulásával magyarázható.

A sztöchiometrikus helyettesítési modellt alkalmazva igazoltam, hogy az ikerionos állófázisok alkalmazása során az ellenionok koncentrációjának változtatásával hangolható az elválasztandó komponensek retenciós viselkedése a szelektivitás lényeges megváltozása nélkül. Eredményeimmel bizonyítottam az elektrosztatikus kölcsönhatási mechanizmus meglétét az alkalmazott ikerionos szelektor és a vizsgált ionos karakterü vegyületek között.

A molekulaszerkezet és a kromatográfiás viselkedés közötti összefüggések feltárásával megállapítottam, hogy az aminocsoporton elhelyezkedő szubsztituensek méretének növelése jelentős mértékben járult hozzá a visszatartás csökkenéséhez. A legnagyobb enantioszelektivitást a guanidincsoportot tartalmazó aminosavak elválasztásánál figyeltem meg, melynek oka az alkalmazott szelektor és a vizsgált modellvegyületek között kialakuló elektrosztatikus kölcsönhatások mellett létrejövő H-kötésekkel magyarázható. 
Az elválasztásokat különböző hőmérsékleteken tanulmányozva eredményeim rámutattak, hogy a legtöbb esetben a hömérséklet növelése a retenciós tényező, a szelektivitás és a felbontás csökkenéséhez vezetett. A meghatározott termodinamikai adatok alapján megállapítottam, hogy a ciklusos $\beta$-aminosavak ikerionos állófázisokon történő elválasztását döntően entalpiavezérelt folyamatok kísérték, de $Z W I X(-)$ oszlop alkalmazása során megfigyeltem entrópia által vezérelt elválasztásokat is.

A két alkalmazott ikerionos állófázis elválasztóképességét összehasonlítva eredményeim rávilágítottak arra, hogy a vizsgált ciklusos $\beta$-aminosavak elválasztásakor a $Z W I X(-)$ oszlop szelektívebbnek bizonyult, míg az $N$-amidált származékok esetén a $Z W I X(+)$ állófázis biztosította az enantiomerek hatékonyabb megkülönböztetését.

Az egymással pszeudoenantiomer viszonyban álló kinin és kinidin alapú ioncserélő állófázisok alkalmazása révén eredményeim alapján elmondható, hogy az $N$-szubsztituált aminosav enantiomerek elúciós sorrendje minden esetben megfordítható az alkalmazott oszlopok cseréjével anélkül, hogy időigényes módon újabb alkalmas kromatográfiás módszert dolgoznánk ki.

\section{Módosított poliszacharid alapú állófázisokon sikeresen megvalósítottam limonén} alapú biciklusos 1,3-aminoalkohol, valamint 1,3,5- és 1,3,6-aminodiol származékok elválasztását normál fázisú folyadékkromatográfia (NP-LC) és szuperkritikus folyadékkromatográfia (SFC) alkalmazásával.

Mindkét kromatográfiás technika alkalmazása során a mozgófázis összetételének változtatásával tipikus normál fázisú kromatográfiás viselkedést figyeltem meg, azaz a mozgófázis apoláris oldószertartalmának ( $n$-hexán és $\mathrm{CO}_{2}$ ) növelésével a retenció jelentős mértékü növekedése volt jellemző. Eredményeim rámutattak, hogy az alkalmazott alkohol módosítók szénlánc hosszának növelése növekvő visszatartáshoz vezetett, kismértékben változtatva a szelektivitást, mely arra enged következtetni, hogy a vizsgált vegyületek a csökkent szolvatáció miatt erősebben kötődtek az állófázishoz. NP-LC körülmények között 2-PrOH, míg SFC alkalmazásakor $\mathrm{MeOH}$ biztosította a limonén alapú enantiomerek leghatékonyabb megkülönböztetését.

Megállapítottam, hogy az aminodiol vegyületeken levo „extra” hidroxilcsoport a szelektorral való erősebb H-kötések kialakulásához járult hozzá, nagyobb retenciót és szelektivitást eredményezve. Összehasonlítva a mono- és dibenzil analógok kromatográfiás viselkedését, a két benzilcsoporttal rendelkező vegyületek elválasztását nagyobb visszatartás 
és enantioszelektivitás kísérte, melyet az alkalmazott szelektor és a komponensek között létrejövő $\pi-\pi$ kölcsönhatások királis felismeréshez való hozzájárulásával értelmeztem.

A királis elválasztás hőmérsékletfüggésének vizsgálata során kapott eredményeim rávilágítottak arra, hogy a kromatográfiás tulajdonságok, úgymint a retenció és a szelektivitás általában csökkentek a hőmérséklet emelésével. SFC körülmények között az elválasztás hatékonysága sok esetben javult a hőmérséklet emelésével, mely az oszlop kinetikai hatékonyságának növekedésével magyarázható. A termodinamikai összefüggések vizsgálata során megállapítottam, hogy a biciklusos aminoalkohol és aminodiol vegyületek elválasztása a legtöbb esetben entalpiavezérelt volt, de előfordult entrópia által vezérelt elválasztás is.

Összevetve a két alkalmazott kromatográfiás technikát, a biciklusos aminoalkohol és aminodiol analógok enantioszelektív elválasztása a legtöbb esetben SFC módban hatékonyabbnak bizonyult, melynek magyarázata a $\mathrm{CO}_{2}$ alapú mozgófázisok kisebb viszkozitásában és az ebből eredő nagyobb kinetikai hatékonyságban keresendő. Az alkalmazott állófázisok elválasztóképességét összehasonlítva megállapítottam, hogy a poliszacharid alapú szelektorok komplementer jelleggel, egymást kiegészítve járultak hozzá a vizsgált vegyületek eredményes elválasztásához.

Az elúciós sorrend meghatározására irányuló vizsgálataim rávilágítottak arra, hogy SFC körülmények között föként a szelektor poliszacharid váza (cellulóz vagy amilóz), míg NP-LC módban mind a poliszacharid váz, mind a szelektoron fellelhető szubsztituensek anyagi minősége volt hatással az enantiomerek elúciós sorrendjének alakulására. 


\section{Summary}

I performed the enantioselective chromatographic separation of compounds bearing pharmaceutical importance, namely limonene-based carbocyclic $\beta$-amino acids, $N$ substituted cyclic $\beta$-amino acids and limonene-based bicyclic 1,3-aminoalcohols and 1,3,5and 1,3,6-aminodiols using chiral stationary phases. During my work I investigated the process of enantiorecognition and the influences of the chromatographic conditions on the chiral separation.

1. Polar-ionic and reversed-phase high-performance liquid chromatographic separations of limonene-based cyclic $\beta$-amino acid enantiomers were accomplished by using macrocyclic glycopeptide-based chiral selectors applying Chirobiotic ${ }^{T M} T, T A G$ and $\boldsymbol{R}$.

By investigating the effects of the nature and composition of the mobile phase, it was established that retention increased with increasing concentration of water which was resulted by enhanced hydrophobic interactions inside the "basket" of the glycopeptide. When $\mathrm{MeOH}$ content of the mobile phase was higher, the values of the retention factor increased due to the formation of the ionic and dipolar interactions between the studied analytes and applied selectors. On the basis of my results $\mathrm{MeOH}$ and 1-PrOH were the most effective of the applied alcohol modifiers for the enantioseparation of carbocyclic $\beta$-amino acid compounds.

Applying the stoichiometric displacement model, I was first to prove that ioninteractions mechanism is operative in chiral discrimination using macrocyclic glycopeptide-based chiral stationary phases. The obtained slopes of $\lg k_{1}$ vs. $\lg c$ curves showed that teicoplanin aglycon exhibits a "zwitterionic character" in the course of enantioseparation of carbocyclic $\beta$-amino acids.

To quantify the effects of the sugar units of Chirobiotic ${ }^{T M}$ columns, the calculated $\Delta\left(\Delta G^{\circ}\right)_{T A G}-\Delta\left(\Delta G^{\circ}\right)_{T}$ values revealed that in the presence of sugar moieties, the enantiorecognition is sterically hindered. Comparing the separation performances of the investigated macrocyclic glycopeptide-based chiral stationary phases, of the three Chirobiotic $^{T M}$ columns, Chirobiotic ${ }^{T M} T A G$ appeared most suitable for the enantioseparation of limonene-based cyclic $\beta$-amino acid analogs.

During the investigation of the temperature dependence of separation, I observed a chromatographic behavior different from the so-called thermodynamic effect most often experienced. Decreasing retention with increasing column temperature was accompanied 
with higher enantioselectivity and in many cases the resolution also improved. Chromatographic data were utilized to construct van't Hoff plots and the thermodynamic parameters were calculated. According to my results the enantioselective discrimination was in most cases entropically-driven, but I also observed enthalpically-driven separations.

I established that neither the configuration of the carbon atom attached to the carboxyl group nor the configuration of the carbon atom attached to the amino or 2-propyl group determined the elution sequence of limonene-based carbocyclic $\beta$-amino acids.

\section{HPLC methods in polar-ionic mode were performed and discussed for the separation} of enantiomers of $\mathrm{N}$-substituted derivatives by using Cinchona alkaloid- and chiral sulfonic acid-based chiral stationary phases, namely $Z W I X(+)^{T M}$ and $Z W I X(-)^{T M}$.

By investigating the effect of bulk solvent composition on the chromatographic parameters it was established that an increase in aprotic $\mathrm{MeCN}$ content in the mobile phase resulted in increased retention factors. The observed chromatographic behavior in $\mathrm{MeCN}-$ rich eluents can be explained by decreased solvation shell of the ionized compounds which enforces the electrostatic attraction due to the reduced distances of the involved charged sites.

Applying the stoichiometric displacement model it was proved that the retention can be conveniently regulated without significantly altering selectivity values by using zwitterionic stationary phases. My results indicated the existence of two pairs of electrostatic interaction mechanisms between zwitterionic selector and the investigated ionizable compounds.

Investigating the correspondences between the molecular structure and chromatographic behavior it was proved that with an increase in the degree of substitution of the amino group the retention decreased. The highest enantioselectivity values were observed for the amidinated amino acids, which can be explained by an additional hydrogen bonding increment on top of the electrostatic interactions.

Studying the effects of column temperature on the chiral separations my results demonstrated that the values of retention factor, selectivity and resolution decreased with increasing temperature in most cases. According to the thermodynamic study it has been found that the enantiorecognition was decisively ethalpically-driven but enthropicallydriven separations were also observed on $Z W I X(-)^{T M}$ column.

Comparing the two zwitterionic selectors, the $Z W I X(-)^{T M}$ column was more selective for the separation of the studied cyclic $\beta$-amino acids, however, for the $N$-amidino compounds the $Z W I X(+)^{T M}$ afforded more effective separations. 
Using the pseudo-enantiomeric quinine- and quinidine-based chiral stationary phases I demonstrated that the enantiomers of $N$-substituted cyclic $\beta$-amino compounds can be made to elute in reversed order upon changing the applied zwitterionic columns without the need for time-consuming development of new chromatographic methods.

\section{Enantioseparation of limonene-based bicyclic 1,3-aminoalcohols and 1,3,5- and} 1,3,6-aminodiols was optimized in normal-phase high-performance liquid chromatographic (NP-LC) and supercritical fluid chromatographic (SFC) modalities applying derivatized polysaccharide-based chiral stationary phases.

Investigating the retention behavior, typical normal phase behavior was found in both NP LC and SFC; an increased content of apolar $n$-hexane or $\mathrm{CO}_{2}$ in the mobile phase resulted in an increase retention. According to my results, increasing the carbon chain length of applied alcohol generally resulted in an increase in retention with only a minor effect on enantiodiscrimination. This observed chromatographic behavior proved that the solvation of the limonene analogs reduced in these solvents and the studied compounds stayed in the stationary phase rather than in the mobile phase. The use of 2-PrOH in NP LC and $\mathrm{MeOH}$ in SFC was favored for the enantioseparation of the investigated limonene-based analoges.

On the basis of the explored structure-retention relationships it can be stated that the extra OH-group on the aminodiol compounds contributed to stronger H-bond interactions with the selector which resulted in higher retention and selectivity. Comparing the chromatographic behavior of methylbenzyl- and dibenzyl-susbtitution on the $\mathrm{N}$-atom a higher retention and selectivity was observed for dibenzyl derivatives due to the enhanced $\pi-\pi$ interactions with the selector.

The study of the influences of the temperature on the chiral separation revealed that the chromatographic properties such as retention and selectivity generally decreased with increasing column temperature. Under SFC conditions, the resolution improved in many cases with increasing temperature which can be explained by an increase of the kinetic efficiency of the applied column. On the basis of the thermodynamic study the separations were found to be enthalpically controlled, but entropically controlled separations also took place.

A comparison between NP LC and SFC techniques in terms of succes rate revealed that, in general, more and better separations could be achieved by SFC which can be explained by the lower viscosity of the $\mathrm{CO}_{2}$-based mobile phases and the resulting higher kinetic efficiency. The comparison of the separation performance of the applied stationary 
phases revealed that the amylose- and cellulose-based chiral stationary phases exhibit a complementary characters, which led to succesful resolution.

The determination of the elution sequences revealed that in SFC only the structure of the polysaccharide backbone (cellulose or amylose) affected the elution sequence, while in NP LC both the polysaccharide backbone and the structure of the selector did so. 


\section{Irodalomjegyzék}

[1] N. M. Maier, P. Franco, W. Lindner, Journal of Chromatography A 906 (2001) 333.

[2] FDA's policy statement for the development of new stereoisomeric drugs, Chirality, 4 (1992) 338-40.

[3] E. Sanganyado, Z. Lu, Q. Fu, D. Schlenk, J. Gan, Water Research 124 (2017) 527542.

[4] J. W. Timothy, Analytical Chemistry 78 (2006) 3947-3956.

[5] L. Pasteur, The Foundation of Stereochemistry, Memoirs by Pasteur, van't Hoff, Le Bell and Wislicenus (G. M. Richardson), American Book Company, New York (1901) $1-33$.

[6] I. Huber, Gyógyszerészi sztereokémia ismeretek, PTE, ÁOK, Gyógyszerészi Kémiai Intézet (2013) 327.

[7] G. M. Henderson, H. G. Rule, Nature 142 (1938) 917-918.

[8] M. Lämmerhofer, Journal of Chromatography A 1217 (2010) 814-856.

[9] C. Fernandes, M. E. Tiritan, S. Cravo, Y. Z. Phyo, A. Kijjoa, A. M. S. Silva, Q. B. Cass, M. M. M. Pinto, Chirality 29 (2017) 430-442.

[10] G. K. E. Scriba, Journal of Chromatogaphy A 1467 (2016) 56-78.

[11] K. Kalíková, M. Riesová, E. Tesařová, Central European Journal of Chemistry 10 (2011) 450-471.

[12] G. Felix, A. Berthod, Separation and Purification Reviews 36 (2007) 285-481.

[13] L. H. Easson, E. Stedman, Biochemical Journal 27 (1933) 1257-1266.

[14] C. E. Dalgliesh, Journal of the Chemical Society (Resumed) 137 (1952) 3940-3942.

[15] W. H. Pirkle, T. C. Pochapsky, Chemical Reviews 89 (1989) 347-362.

[16] V. A. Davankov, Chirality 9 (1997) 99-102.

[17] D. W. Armstrong, In Pittsburgh Conference Abstracts (1994) 572.

[18] D. W. Armstrong, Y. Tang, S. Chen, Y. Zhou, C. Bagwill, J. R. Chen, Analitical Chemistry 66 (1994) 1473-1484.

[19] D. W. Armstrong, Y. Liu, K. H. Ekborg-Ott, Chirality 7 (1995) 474-497.

[20] I. Ilisz, T. Orosz, A. Péter, Chiral Separations, Methods and Protocols, Humana Press (2019), 201-237.

[21] T. L. Xiao, D. W. Armstrong, Chiral Separations, Methods and Protocols, Humana Press (2004) 113-171. 
[22] I. Ilisz, Z. Pataj, A. Aranyi, A. Péter, Separation \& Purification Reviews 41 (2012) 207-249.

[23] E. N. Shapovalova, I. A. Fedorova, I. A. Anan'eva, O. A. Shpigun, Journal of Analytical Chemistry 73 (2018) 1064-1075.

[24] T. E. Beesley, J. T. Lee, Journal of Liquid Chromatography \& Related Technologies 32 (2009) 1733-1767.

[25] Y. Liu, A. Berthod, C. R. Mitchell, T. L. Xiao, B. Zhang, D. W. Armstrong, Journal of Chromatography A 978 (2002) 185-204.

[26] G. Hellinghausen, D. A. Lopez, J. T. Lee, Y. Wang, C. A. Weatherly, A. E. Portillo, A. Berthod, D. W. Armstrong, Chirality 30 (2018) 1067-1078.

[27] P. A. Cardoso, I. C. César, Chromatographia 81 (2018) 841-850.

[28] L. Sipos, I. Ilisz, M. Nonn, F. Fülöp, Z. Pataj, D. W. Armstrong, A. Péter, Journal of Chromatography A 1232 (2012) 142-151.

[29] A. Berthod, X. Chen, J. P. Kullmann, D. W. Armstrong, F. Gasparrini, I. D’Acquarica, C. Villani, Analitical Chemistry 72 (2000) 1767-1780.

[30] A. Berthod, Y. Liu, C. Bagwill, D. W. Armstrong, Journal of Chromatography A 731 (1996) 123-137.

[31] A. Berthod, T. L. Xiao, Y. Liu, W. S. Jenks, D. W. Armstrong, Journal of Chromatography A 955 (2002) 53-69.

[32] T. L. Xiao, R. V. Rozhkov, R. C. Larock, D. W. Armstrong, Analytical and Bioanalytical Chemistry 377 (2003) 639-654.

[33] A. Péter, A. Árki, D. Tourwé, E. Forró, F. Fülöp, D. W. Armstrong, Journal of Chromatography A 1031 (2004) 159-170.

[34] Z. Pataj, I. Ilisz, N. Grecsó, M. Palkó, F. Fülöp, D. W. Armstrong, A. Péter, Chirality 26 (2014) 200-208.

[35] A. Berthod, Comprehensive Chirality, 8 (2012) 227-262.

[36] T. L. Xiao, E. Tesarova, J. L. Anderson, M. Egger, D. W. Armstrong, Journal of Separation Science 29 (2006) 429-445.

[37] T. L. Xiao, B. Zhang, J. T. Lee, F. Hui, D. W. Armstrong, Journal of Liquid Chromatography \& Related Technologies 24 (2001) 2673-2684.

[38] J. C. J. Barna, D. H. Williams, D. J. M. Stone, T. W. C. Leung, D. M. Doddrell, Journal of the American Chemical Society 106 (1984) 4895-4902.

[39] M. J. Ramansky, B. M. Limson, J. E. Hawkins, Antibiotics Annual (1956-57) 706.

[40] D. C. Jordan, Antibiotics, Berlin, Heidelberg, New York: Springer (1967) 84-89. 
[41] M. Nieto, H. R. Perkins, Biochemical Journal 123 (1971) 789-803.

[42] D. L. Boger, Y. Nomoto, B. R. Teegarden, The Journal of Organic Chemistry 58 (1993) 1425-1433.

[43] D. W. Armstrong, M. P. Gasper, K. L. Rundlett, Journal of Chromatography A 689 (1995) 285-304.

[44] K. Ekborg-Ott, Y. Liu, D. W. Armstrong, Chirality 10 (1998) 434-483.

[45] M. Lämmerhofer, W. Lindner, Journal of Chromatography A 741 (1996) 33-48.

[46] N. Grubhofer, L. Schleith, Naturwisenshaften 40 (1953) 508-512.

[47] N. Grubhofer, L. Schleith, Hoppe-Seyler's Zeitschrift Physiologische Chemie 296 (1954) 262-266.

[48] S. Izumoto, U. Sakaguchi, H. Yoneda, Bulletin of the Chemical Society of Japan 56 (1983) 1646-1651.

[49] K. Miyoshi, M. Natsubori, N. Dohmoto, S. Izumoto, H. Yoneda, Bulletin of the Chemical Society of Japan 58 (1985) 1529-1534.

[50] C. Pettersson, Journal of Chromatography 316 (1984) 553-567.

[51] C. Pettersson, G. Schill, Journal of Liquid Chromatography 9 (1986) 269-290.

[52] C. Pettersson, C. Gioeli, Journal of Chromatography 435 (1988) 225-228.

[53] C. Rosini, C. Bertucci, D. Pini, P. Altemura, P. Salvadori, Chromatographia 24 (1987) 671-676.

[54] C. V. Hoffmann, M. Lämmerhofer, W. Lindner, Journal of Chromatography A 1161 (2007) 242-251.

[55] D. Wolrab, P. Frühauf, M. Kohout, W. Lindner, Journal of Separation Science 36 (2013) 2826-2837.

[56] C. V. Hoffmann, R. Pell, M. Lämmerhofer, W. Lindner, Analytical Chemistry 80 (2008) 8780-8789.

[57] C. V. Hoffmann, R. Reischl, N. M. Maier, M. Lämmerhofer, W. Lindner, Journal of Chromatography A 1216 (2009) 1147-1156.

[58] C. V. Hoffmann, R. Reischl, N. M. Maier, M. Lämmerhofer, W. Lindner, Journal of Chromatography A 1216 (2009) 1157-1166.

[59] I. Ilisz, A. Bajtai, A. Péter, W. Lindner, Chiral Separations, Methods and Protocols, (2019) 251-277.

[60] M. Kotake, T. Sakan, N. Nakamura, S. Senoh, Journal of American Chemical Society 73 (1951) 2973-2974.

[61] W. Mayer, F. Merger, Liebigs Annalen der Chemie 644 (1961) 65-69. 
[62] A. Lüttringhaus, U. Hess, H. J. Rosenbaum, Zeitschrift für Naturforschung B 22 (1967) 1296-1300.

[63] G. Hesse, R. Hagel, Chromatographia 6 (1973) 277-280.

[64] Y. Okamoto, M. Kawashima, K. Hatada, Journal of the American Chemical Society 106 (1984) 5357-5359.

[65] E. R. Francotte, Journal of Chromatography A 906 (2001) 379-397.

[66] P. Franco, A. Senso, L. Oliveros, C. Minguillón, Jounral of Chromatography A 906 (2001) 155-170.

[67] T. Ikai, C. Yamamoto, M. Kamigaito, Y. Okamoto, Journal of Chromatography B 875 (2008) 2-11.

[68] B. Chankvetadze, Journal of Chromatography 1269 (2012) 26-51.

[69] I. Ilisz, A. Péter, W. Lindner, Trends in Analytical Chemistry 81 (2016) 11-22.

[70] B. Chankvetadze, Chiral Separations, Methods and Protocols (2019) 93-126.

[71] B. Chankvetadze, Trends in Analytical Chemistry 122 (2020) 115709.

[72] G. K. E. Scriba, Chiral Separations, Methods and Protocols (2019) 1-33.

[73] T. E. Beesley, LC GC North America 28 (S4) (2010) 32-37.

[74] M. Lämmerhofer, Journal of Chromatography A 1217 (2010) 814-856.

[75] J. M. Padró, S. Keunchkarian, Microchemical Journal 140 (2018) 142-157.

[76] E. Francotte, R. M. Wolf, D. Lohmann, R. Mueller, Journal of Chromatography 347 (1985) 25-37.

[77] H. J. Schneider, Angewante Chemie International Edition 48 (2019) 3924-3977.

[78] P. Peluso, V. Mamane, S. Cossu, Chirality 27 (2015) 667-684.

[79] M. Saito, Journal of Bioscience and Bioengeneering 115 (2013) 590-599.

[80] K. De Klerck, D. Mangelings, Y. V. Heyden, Journal of Pharmaceutical and Biomedical Analysis 69 (2012) 77-92.

[81] E. Klesper, A. H. Corwin, D. A. Turner, The Journal of Organic Chemistry 27 (1962) 700-701.

[82] D. R. Gere, R. Board, D. McManigill, Analytical Chemistry 54 (1982) 736-740.

[83] A. Tarafder, Trends in Analytical Chemistry 81 (2016) 3-10.

[84] E. Lesellier, Journal of Chromatography A 1216 (2009) 1881-1890.

[85] C. West, E. Lesellier, Journal of Chromatography A (2008) 21-39.

[86] H. Chen, C. Horváth, Journal of Chromatography A 705 (1995) 3.

[87] P. L. Zhu, J. W. Dolan, L. R. Snyder, N. M. Djordjevic, D. W. Hill, J. T. Lin, L. C. Sander, L. van Heukelem, Journal of Chromatography A 756 (1996) 63. 
[88] A. Péter, G. Török, D. W. Armstrong, G. Tóth, D. Tourwé, Journal of Chromatography A 828 (1998) 177.

[89] T. L. Chester, J. W. Coym, Journal of Chromatography A, 1003 (2003) 101.

[90] L. D. Asnin, M. V. Stepanova, Journal of Separation Science 41 (2018) 1319-1337.

[91] A. Sepsey, É. Horváth, M. Catani, A. Felinger, Journal of Chromatography A 1611 (2020) 460594.

[92] F. Fülöp, T. A. Martinek, G. K. Tóth, Chemical Society Reviews 35 (2006) 323-334.

[93] L. Kiss, F. Fülöp, Chemical Reviews 114 (2014) 1116-1169.

[94] M. S. I. El Alami., M. A. El Amrani, F. Agbossou-Niedercorn, I. Suisse, A. Mortreux, Chemistry - A Europian Journal 21 (2015) 1398-1413.

[95] S. G. Davies, A. D. Smith, P. D. Price, Tetrahedron: Asymmetry 16 (2005) 28332891.

[96] S. G. Davies, A. M. Fletcher, P. M. Roberts, J. E. Thomson, Tetrahedron: Asymmetry 23 (2012) 1111-1153.

[97] Z. Szakonyi, R. Sillanpää, F. Fülöp, Beilstein Journal of Organic Chemistry 10 (2014) 2738-2742.

[98] R. B. Raffa, E. Friderichs, W. Reimann, R. P. Shank, E. E. Codd, J. L. J. Vaught, The Journal of Pharmacology and Experimental Therapeutics 260 (1992) 275-285.

[99] M. S. Coumar, C. N. Chang, C. T. Chen, X. Chen, C. H. Chien, T. Y. Tsai, W. T. Jiang, Bioorganic \& Medicinal Chemistry Letters 17 (2007) 1274-1279.

[100] E. Largy, W. Liu, A. Hasan, D. M. Perrin, Chemistry-A European Journal, 20 (2014), 1495-1499.

[101] S. Chandrasekhar, S. Mohapatra, J. S. Yadav, Tetrahedron 55 (1999) 4763-4768.

[102] K. Toribatake, S. Miyata, Y. Naganawa, H. Nishiyama, Tetrahedron 71 (2015) 32033208.

[103] A. Grajewska, M. D. Rozwadowska, Tetrahedron: Asymmetry 18 (2007) 803-813.

[104] Z. Szakonyi, F. Fülöp, Amino Acids 41 (2011) 597-608.

[105] Z. Szakonyi, Á. Csőr, A. Csámpai, F. Fülöp, Chemistry-A European Journal 22 (2016) 7163-7173.

[106] T. Le Minh, F. Fülöp, Z. Szakonyi, European Journal of Organic Chemistry 45 (2017) 6708-6713.

[107] F. Fülöp, Chemical Reviews 101 (2001) 2181-2204.

[108] A. Kuhl, M. G. Hahn, M. Dumic, J. Mittendorf, Amino Acids 29 (2005) 89-100. 
[109] R. Petraitiene, V. Petraitis, A. M. Kelaher, A. A. Sarafandi, D. Mickiene, A. H. Groll, T. Sein, J. Bacher, T. J. Walsh, Antimicrobial Agents and Chemotherapy 49 (2005) 2084-2092.

[110] D. L. Steer, R. A. Lew, P. Perlmutter, A. I. Smith, M. I. Aguilar, Current Medicinal Chemistry 9 (2002) 811-822.

[111] J. L. Price, W. S. Horne, S. H. Gellman, Journal of the American Chemical Society 129 (2007) 6376-6377.

[112] I. M. Mándity, E. Wéber, T. A. Martinek, G. Olajos, G. K. Tóth, E. Vass, F. Fülöp, Angewante Chemie International Edition 48 (2009) 2171-2175.

[113] T. A. Martinek, F. Fülöp, Chemical Society Reviews 41 (2012) 687-702.

[114] H. Brückner, Chromatographia 24 (1987) 725-738.

[115] S. Hess, K. R. Gustafson, D. J. Milanowski, E. Alvira, M. A. Lipton, L. K. Panell, Journal of Chromatography A 1035 (2004) 211-219.

[116] M. Tsesarskaia, E. Galindo, G. Szókán, G. Fisher, Biomedical Chromatography 23 (2009) 581-587.

[117] R. Pell, S. Sic, W. Lindner, Journal of Chromatography A 1269 (2012) 287-296.

[118] A. Mandl, L. Nicoletti, M. Lämmerhofer, W. Lindner, Journal of Chromatography A 858 (1999) 1-11.

[119] V. Piette, W. Lindner, J. Crommen, Journal of Chromatography A 948 (2002) 295302.

[120] W. Kopaciewicz, M. A. Rounds, F. Fausnaugh, F. E. Regnier, Journal of Chromatography A 266 (1983) 3-21.

[121] J. Stahlberg, Journal of Chromatography A 855 (1999) 3-55.

[122] G. Lajkó, N. Grecsó, R. Megyesi, E. Forró, F. Fülöp, D. Wolrab, W. Lindner, A. Péter, I. Ilisz, Journal of Chromatography A 1467 (2016) 188-198.

[123] I. Ilisz, N. Grecsó, R. Papousek, Z. Pataj, P. Barták, L. Lázár, F. Fülöp, W. Lindner, A. Péter, Amino Acids 47 (2015) 2279.

[124] N. Grecsó, E. Forró, F. Fülöp, A. Péter, I. Ilisz, W. Lindner, Journal of Chromatography A 1467 (2016) 178-187.

[125] I. D’Acquarica, F. Gasparrini, D. Misiti, G. Zappia, C. Cimarelli, G. Palmieri, A. Carotti, S. Cellamare, C. Villani, Tetrahedron: Asymmetry 11 (2000) 2375-2385.

[126] A. Sztojkov-Ivanov, L. Lázár, F. Fülöp, D. W. Armstrong, A. Péter, Chromatographia 64 (2006) 89-94. 
[127] I. Ilisz, N. Grecsó, M. Palkó, F. Fülöp, W. Lindner, A. Péter, Journal of Pharmaceutical and Biomedical Analysis 98 (2014) 130-139.

[128] I. Ilisz, Z. Gecse, Z. Pataj, F. Fülöp, G. Tóth, W. Lindner, A. Péter, Journal of Chromatography A 1363 (2014) 169-177.

[129] I. Ilisz, N. Grecsó, A. Misicka, D. Tymecka, L. Lázár, W. Lindner, A. Péter, Molecules 20 (2015) 70-87.

[130] G. Lajkó, T. Orosz, N. Grecsó, B. Fekete, M. Palkó, F. Fülöp, W. Lindner, A. Péter, I. Ilisz, Analytica Chimica Acta 921 (2016) 84-94.

[131] Z. A. Al-Othman, I. Ali, M. Asim, T. A. Khan, Combinatorial Chemistry \& High Throughput Screening 15 (2010) 339-346

[132] T. Ikai, Y. Okamoto, Chemical Reviews 109 (2009) 6077-6101.

[133] Y. Okamoto, E. Yashima, Angewandte Chemie International Edition 37 (1998) 1020-1043.

[134] O. Gyllenhaal, M. Stefansson, Journal of Pharmaceutical and Biomedical Analysis 46 (2008) 860-863.

[135] I. Matarashvili, L. Chankvetadze, S. Fanali, T. Farkas, B. Chankvetadze, Journal of Separation Science 36 (2013) 140-147.

[136] C. Xiang, G. Liu, S. Kang, X. Guo, B. Yao, W. Weng, Q. Zeng, Journal of Chromatography A 1218 (2011) 8718-8721.

[137] A. Aranyi, I. Ilisz, A. Péter, F. Fülöp, C. West, Journal of Chromatography A 1387 (2015) 123-133.

[138] S. Khater, C. West, Journal of Chromatography A 1373 (2014) 197-210.

[139] B. Su, Z. Bao, H. Xing, Y. Yang, Q. Ren, Journal of Chromatography A 1216 (2009) 5140-5146.

[140] L. Toribio, M. J. del Nozal, J. L. Bernal, J. Bernal, M. T. Martin, Journal of Chromatography A 1218 (2011) 4886-4891.

[141] R. Sardella, F. Ianni, A. Marinozzi, S. Scorzoni, B. Natalini, Biomedical Chromatography 28 (2014) 159-167.

[142] T. Wang, R. M. Wenslow, Journal of Chromatography A 1015 (2003) 99-110.

[143] I. Ilisz, Z. Gecse, I. Szatmári, F. Fülöp, A. Péter, Biomedical Chromatography 28 (2014) 142-151.

[144] N. Grecsó, I. Ilisz, Z. Gecse, L. Schönstein, F. Fülöp, A. Péter, Biomedical Chromatography 29 (2014) 788-796. 
[145] G. Lajkó, T. Orosz, L. Kiss, E. Forró, F. Fülöp, A. Péter, I. Ilisz, Biomedical Chromatography 30 (2016) 1441-1448. 


\section{Közlemények listája}

\subsection{Az értekezés alapjául szolgáló közlemények}

2017

T. Orosz, N. Grecsó, G. Lajkó, Z. Szakonyi, F. Fülöp, D. W. Armstrong, I. Ilisz, A. Péter Liquid chromatographic enantioseparation of carbocyclic $\beta$-aminoacids possessing limonene skeleton on macrocyclic glycopeptide-based chiral stationary phases Journal of Pharmaceutical and Biomedical Analysis, 145, 119-126.

Impakt faktor: 2,831

2018

T. Orosz, E. Forró, F. Fülöp, W. Lindner, I. Ilisz, A. Péter

Effects of $N$-methylation and amidination of cyclic $\beta$-amino acids onenantioselectivity and retention characteristics using Cinchona alkaloid- and sulfonic acid-based chiral zwitterionic stationaryphases

Journal of Chromatography A, 1535, 72-79.

Impakt faktor: 3,858

2019

T. Orosz, A. Bajtai, T. Minh Le, D. Tanács, Z. Szakonyi, F. Fülöp, A. Péter, I. Ilisz

Chiral high-performance liquid and supercritical fluid chromatographic enantioseparations of limonene-based bicyclic aminoalcohols and aminodiols on polysaccharide-based chiral stationary phases

Biomedical Chromatography, 33, (5), e4517.

Impakt faktor: 1,748

Összesített impakt faktor: 8,437 


\subsection{Az értekezés témájához kapcsolódó, de fel nem használt közlemények}

2016

G. Lajkó, T. Orosz, L. Kiss, E. Forró, F. Fülöp, A. Péter, I. Ilisz

High-performance liquid chromatographic enantioseparation of fluorinated cyclic $\beta^{3}$-amino acid derivatives on polysaccharide-based chiral stationary phases. Comparison with nonfluorinated counterparts

Biomedical Chromatography, 30, 1441-1448.

Impakt faktor: 1,613

G. Lajkó, T. Orosz, N. Grecsó, M. Palkó, F. Fülöp, A. Péter, I. Ilisz

High-performance liquid chromatographic enantioseparation of cyclic $\beta$-aminohydroxamic acids on zwitterionic chiral stationary phases based on Cinchona alkaloids

Analytica Chimica Acta, 921, 84-94.

Impakt faktor: 4,950

2017

G. Lajkó, T. Orosz, I. Ugrai, Z. Szakonyi, F. Fülöp, W. Lindner, A. Péter, I. Ilisz

Liquid chromatographic enantioseparation of limonene-based carbocyclic $\beta$-amino acids on zwitterionic Cinchona alkaloid-based chiral stationary phases

Journal of Separation Science, 40, 3196-3204.

Impakt faktor: 2,415

2020

D. Tanács, T. Orosz, Z. Szakonyi, T. Minh Le, F. Fülöp, A. Péter

High-performance liquid chromatographic enantioseparation of isopulegol-based $\beta$-amino lactone and $\beta$-amino amide analogs on polysaccharide-based chiral stationary phases focusing on the change of the enantiomer elution order

Journal of Chromatography A, https://doi.org/10.1016/j.chroma.2020.461054

Impakt faktor: 3,858

Összesített impakt faktor: 12,836

Összes közlemény impakt faktora: 21,273 


\subsection{Könyvfejezet}

2019

I. Ilisz, T. Orosz, A. Péter

High-performance liquid chromatography enantioseparations using macrocyclic glycopeptide-based chiral stationary phases: An overview

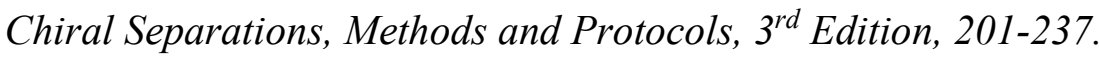

Szerkesztö: Gerhard K. E. Scriba, Könyvfejezet

\subsection{Poszterek}

2018

T. Orosz, G. Németi, A. Bajtai, Z. Szakonyi, F. Fülöp, I. Ilisz, A. Péter

Chiral high-performance liquid and supercritical fluid chromatographic enantioseparations of limonene-based bicyclic aminoalcohols and aminodiols

$24^{\text {th }}$ International Symposium on Analytical and Environmental Problems, Szeged, Hungary

T. Orosz, G. Németi, A. Bajtai, Zs. Szakonyi, F. Fülöp, I. Ilisz, A. Péter

Új, limonén alapú biciklusos aminoalkoholok és aminodiolok elválasztása királis folyadékkromatográfiával és szuperkritikus fluid kromatográfiával

Elválasztástudományi Vándorgyülés, Tapolca, Magyarország

2017

T. Orosz, A. Péter, F. Fülöp, W. Lindner, I. Ilisz

Effects of $N$-substitution on the elution order of cyclic $\beta^{3}$-amino acid enantiomers on Cinchona alkaloid-based zwitterionic and anion exchanger type chiral stationary phases

$45^{\text {th }}$ International Symposium on High Performance Liquid Phase Separations and Related Techniques, Prague, Czech Republic

T. Orosz, A. Péter, F. Fülöp, W. Lindner, I. Ilisz

Study of the effects of structural characteristics on the elution order of cyclic $\beta^{3}$-amino acid enantiomers on anion exchanger-type chiral stationary phases by high-performance liquid chromatography

$11^{\text {th }}$ Balaton Symposium on High-Performance Separation Methods, Siófok, Hungary 
G. Lajkó, T. Orosz, Z. Szakonyi, F. Fülöp, W. Lindner, A. Péter, I. Ilisz

Liquid chromatographic enantioseparation of limonene-based carbocyclic $\beta^{3}$-amino acids on Cinchona alkaloid-based chiral stationary phases

$11^{\text {th }}$ Balaton Symposium on High-Performance Separation Methods, Siófok, Hungary

\section{6}

T. Orosz, G. Lajkó, N. Grecsó, A. Péter, I. Ilisz

High-performance liquid chromatographic study on the enantioseparation of fluorine containing cyclic amino acid derivatives

Proccedings of the $22^{\text {nd }}$ International Symposium on Analytical and Environmental Problems, Szeged, Hungary

G. Lajkó, T. Orosz, N. Grecsó, M. Palkó, F. Fülöp, W. Lindner, A. Péter, I. Ilisz

Enantioseparation of cyclic $\beta$-aminohydroxamic acids by high-performance liquid chromatography on zwitterionic chiral stationary phases based on Cinchona alkaloids

Advances in Chromatography and Electrophoresis \& Chiranal, Olomouc, Czech Republic

G. Lajkó, T. Orosz, N. Grecsó, M. Palkó, F. Fülöp, W. Lindner, A. Péter, I. Ilisz

Ciklikus $\quad \beta$-aminohidroxámsavak enantiomerjeinek nagyhatékonyságú folyadékkromatográfiás elválasztása kinaalkaloid alapú ikerionos állófázisokon

Elválasztástudományi Vándorgyülés, Kecskemét, Magyarország

\section{5}

N. Grecsó, G. Lajkó, T. Orosz, L. Schönstein, F. Fülöp, A. Péter, I. Ilisz

Enantioseparation of amino alcohol analogs possessing 1,2,3,4-tetrahydroisoquinoline skeleton and its derivatives using polysaccharide-based chiral stationary phases

Proceedings of the $21^{\text {st }}$ International Symposium on Analytical and Environmental Problems, Szeged, Hungary 


\subsection{Előadások}

2019

T. Orosz, A. Bajtai, D. Tanács, Z. Szakonyi, F. Fülöp, A. Péter, I. Ilisz

Chiral separation of limonene-based bicyclic aminoalcohols and aminodiols on polysaccharide-based chiral stationary phases

$1^{\text {st }}$ Hungarian-Polish Interdisciplinary Scientific Symposium, Szeged, Hungary

\section{8}

A. Bajtai, D. Tanács, T. Orosz, G. Lajkó, I. Szatmári, F. Fülöp, W. Lindner, I. Ilisz, A. Péter Enantiomer separation of chiral tetrahydroisoquinoline analogs by supercritical fluid chromatography and high-performance liquid chromatography

$24^{\text {th }}$ International Symposium on Analytical and Environmental Problems, Szeged, Hungary

2017

T. Orosz, E. Forró, F. Fülöp, L. Wolfgang, G. Lajkó, A. Bajtai, A. Péter, I. Ilisz

Enantioseparation of cyclic $\beta$-amino acids on ion-exchanger-based chiral stationary phases

Proceedings of the $23^{\text {rd }}$ International Symposium on Analytical and Environmental Problems, Szeged, Hungary

I. Ilisz, A. Péter, T. Orosz, A. Bajtai, G. Lajkó

Enantiomeric separations by ionexchanger-based chiral stationary phases

$11^{\text {th }}$ Balaton Symposium on High-Performance Separation Methods, Siófok, Hungary 
I. Ilisz, T. Orosz, A. Péter, N. Grecsó, G. Lajkó, F. Fülöp

Exploring the applicability of polysaccharide-based chiral stationary phases for the enantioseparations of compounds of pharmacological interest in high-performance liquid chromatography

Advances in Chromatography and Electrophoresis \& Chiranal, Olomouc, Czech Republic

I. Ilisz, T. Orosz, N. Grecsó, G. Lajkó, F. Fülöp, W. Lindner, A. Péter

Új típusú ikerionos királis állófázisok alkalmazása a nagyhatékonyságú folyadékkromatográfiában

Elválasztástudományi Vándorgyülés, Kecskemét, Magyarország

A. Péter, I. Ilisz, G. Lajkó, T. Orosz, F. Fülöp

Királis kromatográfia poliszacharid-alapú állófázisokon

Elválasztástudományi Vándorgyülés, Kecskemét, Magyarország 


\section{Köszönetnyilvánítás}

Ezúton szeretném köszönetemet és hálámat kifejezni témavezetőmnek, Dr. Ilisz István intézetvezető egyetemi docensnek, hogy lehetőséget biztosított a Gyógyszeranalitikai Intézetben doktori munkám kísérleteinek elvégzésére. Mindvégig hasznos szakmai tanácsaival segítette és irányította munkám sikeres elvégzését, valamint értekezésem elkészítését. Köszönöm, hogy töretlen támogatásával nagymértékben hozzájárult szakmai fejlődésemhez, valamint akár szakmailag, akár barátilag volt rá szükségem, mindig számíthattam rá és hitt bennem.

Megkülönböztetett köszönet illeti Prof. Dr. Péter Antal emeritus professzort, amiért kiváló szakmai tudásával és önzetlen támogatásával rengeteg segítséget nyújtott kutatómunkám elvégzése során, illetve a felmerülő problémák megoldásában bármikor fordulhattam hozzá. Emellett hálás vagyok mindazért, amit emberileg kaptam tőle.

Szeretnék köszönetet mondani Prof. Dr. Fülöp Ferenc akadémikusnak és munkatársainak, hogy kiváló munkájuk eredményeivel az én kutatásom előrejutását is segítették.

Köszönöm Prof. Dr. Galbács Gábor tanszékvezető egyetemi tanárnak, hogy egykor a Szervetlen és Analitikai Kémiai Tanszéken nagyszerü kutatók között dolgozhattam.

Hálás vagyok egykori és jelenlegi munkatársaimnak, Dr. Grecsó Nórának, Lajkó Gyulának, illetve Bajtai Attila és Tanács Dániel $\mathrm{PhD}$ hallgatóknak, akik szakmai közremüködésükkel, illetve a laboratóriumban kialakított remek légkörrel járultak hozzá munkám hatékonyságához és sikerességéhez.

Köszönettel gondolok a Gyógyszeranalitikai Intézet valamennyi dolgozójára a munkám során nyújtott szakmai és baráti támogatásukért, biztató szavaikért.

Hálás szívvel köszönöm Anyukámnak, Apukámnak és testvéremnek, Moncsinak végtelen szeretetüket, gondoskodásukat és támogatásukat, amely nélkül most nem tarthatnék itt. Végül, de nem utolsó sorban tiszta szívből köszönöm vőlegényemnek, Bercinek kitartó türelmét, mellyel végig kísért ezen az úton és hogy támaszkodhatok rá az élet minden területén. 


\section{Függelék}

\subsection{Monoterpénvázas vegyületek válogatott kromatogramjai}

\subsubsection{Limonén alapú karbociklusos $\beta$-aminosavak válogatott kromatogramjai}
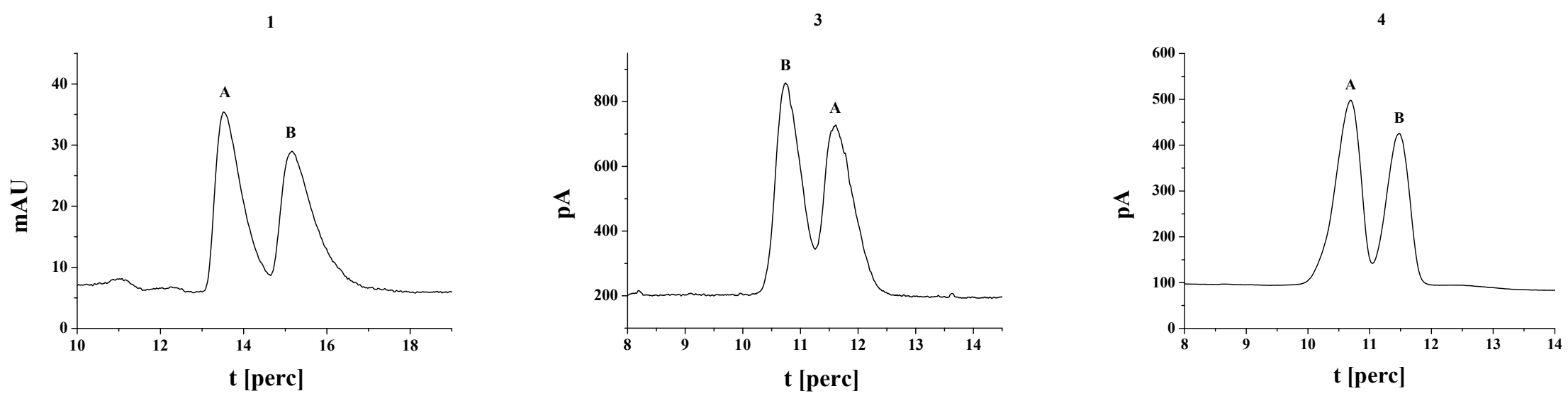

Kromatográfiás körülmények: oszlopok, 1 vegyület esetén Chirobiotic ${ }^{T M} T A G, \mathbf{3}$ és $\mathbf{4}$ vegyület esetén Chirobiotic $^{T M} T$; mozgófázis, $\mathbf{1}$ vegyület esetén $0,1 \%$ TEAA $(\mathrm{pH}=5,00) / 2-\mathrm{PrOH}(90 / 10 v / v), 3$ vegyület esetén $0,1 \%$ TEAA(pH=5,00)/1-PrOH $(90 / 10 v / v), 4$ vegyület esetén $0,1 \%$ TEAA(pH=5,00)/MeOH (10/90 v/v); áramlási sebesség, $0,8 \mathrm{ml} \mathrm{perc}{ }^{-1}$; detektálás, 1 vegyület esetén $210 \mathrm{~nm} ; 3$ és 4 vegyület esetén korona kisülési detektor; hőmérséklet, $\mathrm{T}=25 \mathrm{C}^{\circ}$. 


\subsubsection{Biciklusos 1,3-aminoalkohol és 1,3,5-, és 1,3,6-aminodiol analógok válogatott kromatogramjai}
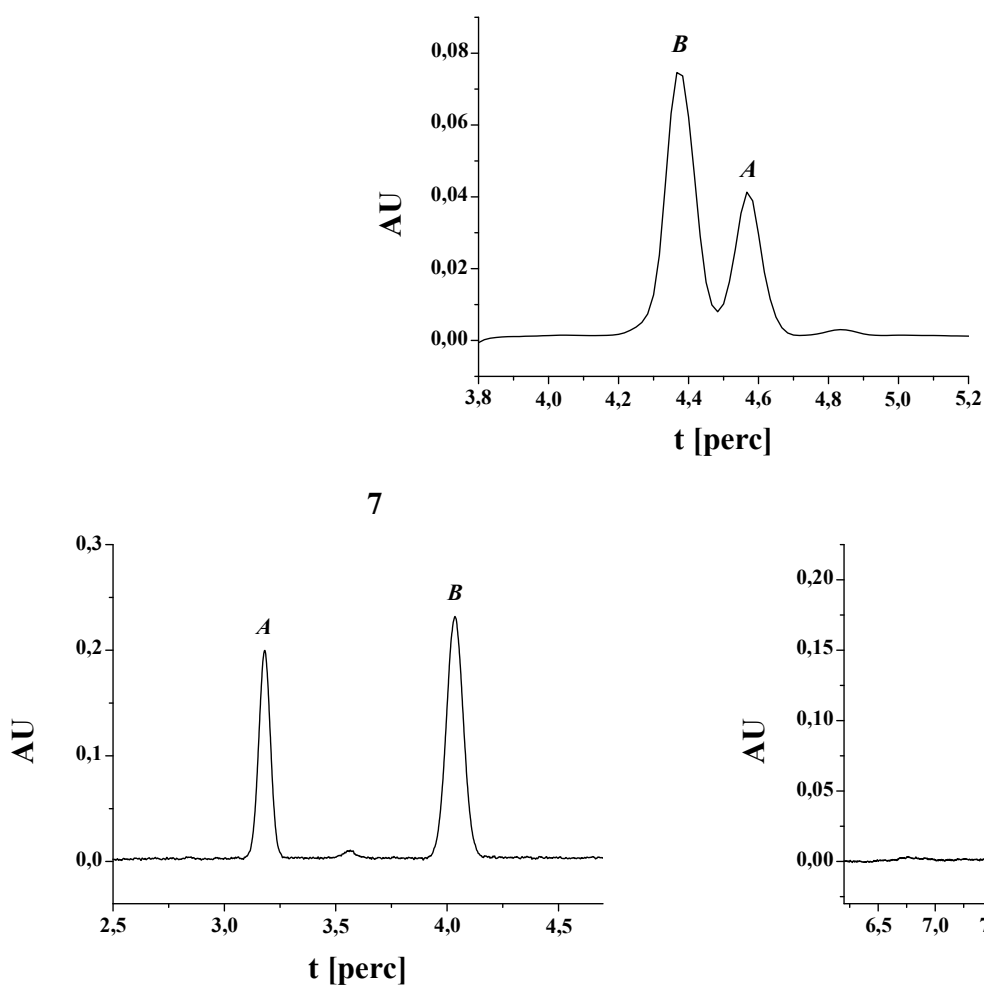

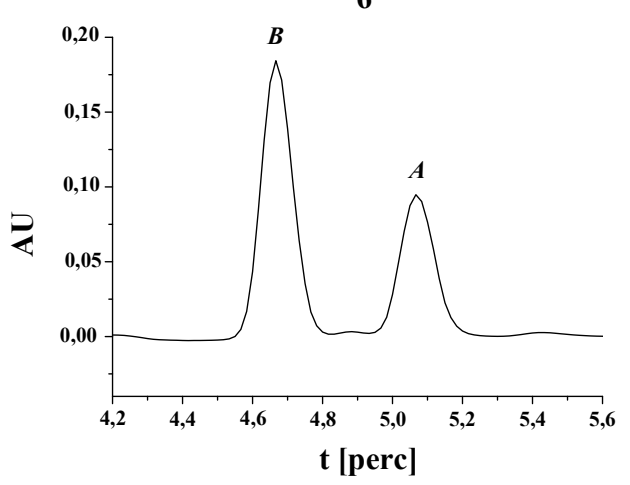

8

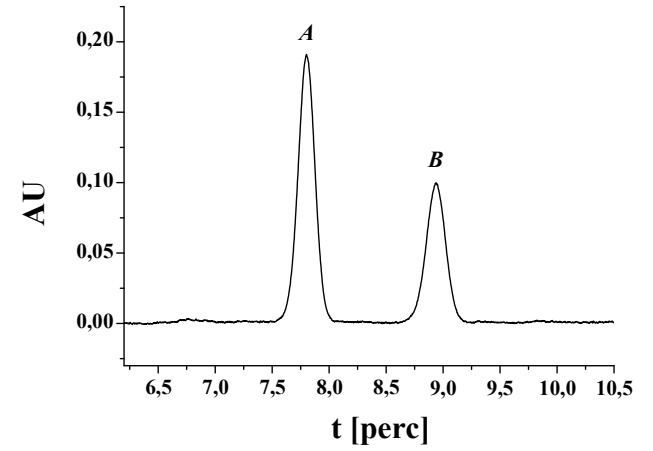

9

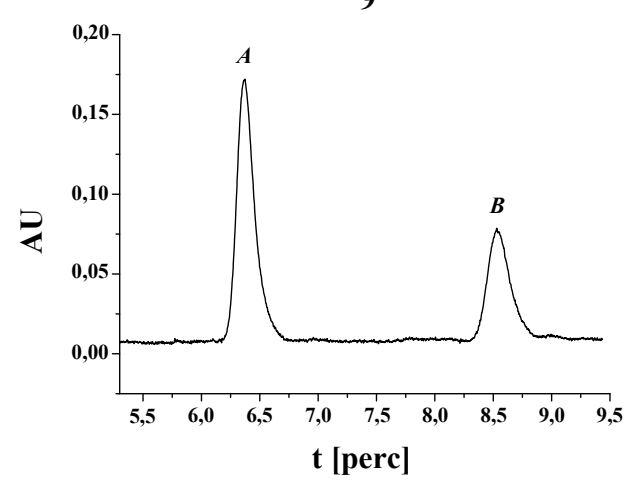

Kromatográfiás körülmények: oszlopok, 5-7 vegyületek esetén Lux Amylose-1, 8 vegyület esetén Lux i-Cellulose-5, 9 vegyület esetén Lux Cellulose-2; mozgófázis, 5 és $\mathbf{6}$ vegyületek esetén $n$-hexán/2-PrOH/DEA (90/10:0.1 v/v/v), 7 és 9 vegyületek esetén $\mathrm{CO}_{2} / \mathrm{EtOH}(80 / 20 v / v)$ és $20 \mathrm{mM} \mathrm{DEA,} 8$ vegyület esetén $\mathrm{CO}_{2} / \mathrm{MeOH}(80 / 20 v / v)$ és $20 \mathrm{mM}$ DEA; áramlási sebesség, 5 és $\mathbf{6}$ vegyületek esetén 1,0 $\mathrm{ml} \mathrm{perc}^{-1}, 7-\mathbf{9}$ vegyületek esetén 2,0 $\mathrm{ml}_{\text {perc }}^{-1}$; detektálás, 210-260 nm; hömérséklet, $\mathbf{5}, 8$ és 9 vegyületek esetén T=40 $\mathrm{C}^{\circ} ; 6$ vegyület esetén $\mathrm{T}=20 \mathrm{C}^{\circ}, 7$ vegyület esetén $\mathrm{T}=30 \mathrm{C}^{\circ}$. 
11.2. $N$-metilszubsztituált és amidált ciklusos $\beta$-aminosavak válogatott kromatogramjai
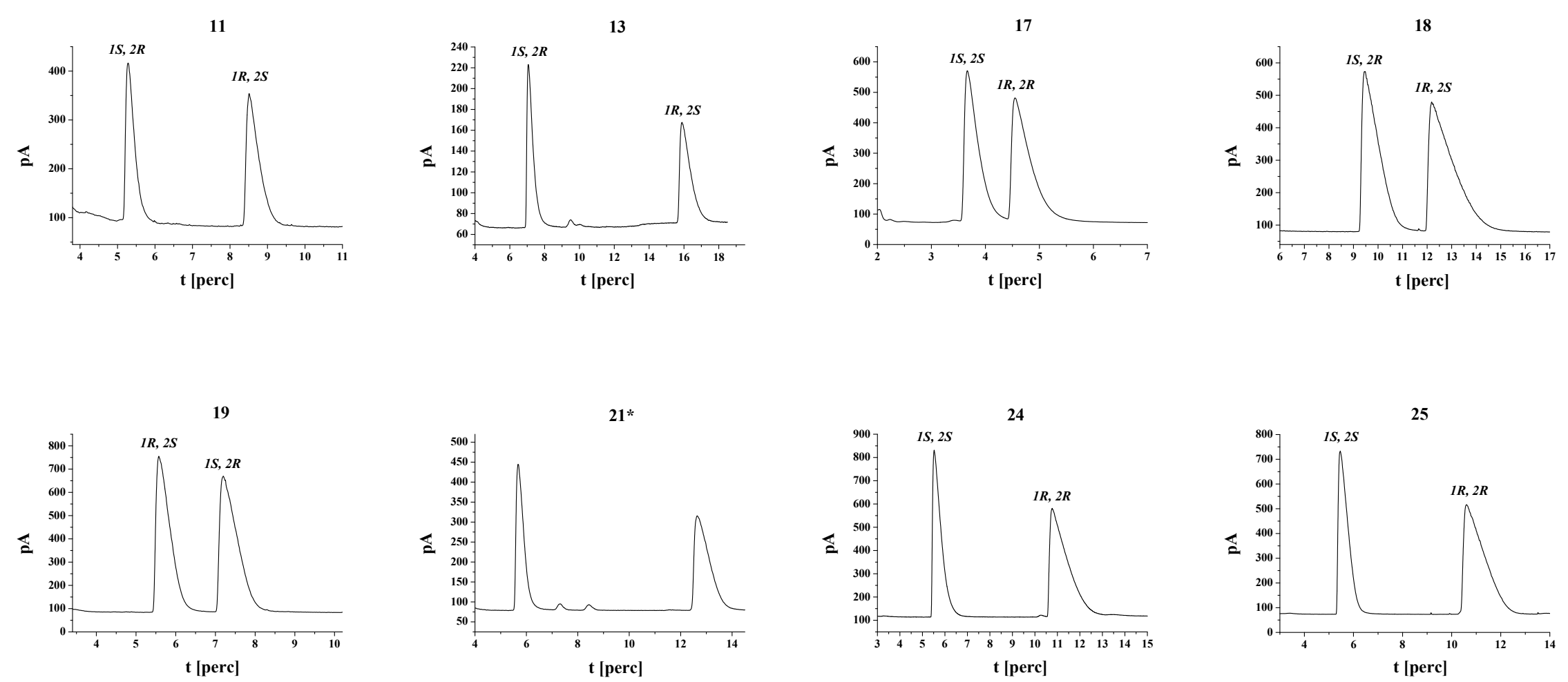

Kromatográfiás körülmények: oszlopok, 11, 13 és 21 vegyületek esetén Chiralpak ${ }^{\circledR} Z W I X(+), 17,18,19,24$ és 25 vegyületek esetén Chiralpak ${ }^{\circledR} Z W I X(-)$; mozgófázis, 11, 13, 17, 19, 21, 24 és 25 vegyületek esetén MeOH/MeCN (60/40 v/v) és $25 \mathrm{mM}$ TEA és $50 \mathrm{mM}$ FA, 18 vegyület esetén MeOH/MeCN $(60 / 40 v / v)$ és $6.25 \mathrm{mM}$ TEA és $12.5 \mathrm{mM}$ FA; áramlási sebesség, $0,6 \mathrm{ml}_{\text {perc }}{ }^{-1}$; detektálás, korona kisülési detektor; hömérséklet, 17, 18, 19, 24 és 25 vegyületek esetén $\mathrm{T}=25^{\circ} \mathrm{C}, 11$ és 13 vegyületek esetén $\mathrm{T}=5^{\circ} \mathrm{C}, \mathbf{2 1}$ vegyület esetén $\mathrm{T}=30^{\circ} \mathrm{C}$; *elúciós sorrend tiszta enantiomer hiányában nem lett meghatározva. 